\title{
Polska bibliografia antyku chrześcijańskiego 2017-2019
}

\section{Działy tematyczne}

1. Prace zbiorowe (antologie tekstów i opracowania)

2. Bibliografie i problemy metodologiczne

3. Prace ogólne, historie literatury

4. Historia wspólnot, instytucji, okresów historycznych, regionów

5. Historia doktryn (teologia i filozofia)

6. Liturgia

7. Hagiografia, monastycyzm i historia duchowości

8. Archeologia i historia sztuki

9. Biblia

9.1. Apokryfy

9.2. Gnostycyzm

10. Patrystyka i średniowiecze (łacińskie i bizantyńskie)

10.1 Przekłady

10.2. Opracowania

11. Autorzy

12. Recenzje, omówienia

13. Sprawozdania

14. Wybrane publikacje z zakresu kultury klasycznej

14.1. Przekłady

14.2. Opracowania

1 Wykaz stosowanych skrótów, zob. VoxP 48 (2005) s. 437-449 lub www.voxpatrum.pl (zakładka „O czasopiśmie”). 


\section{Prace zbiorowe (antologie tekstów i opracowania)}

Aetas Aurea. Sto lat filologii klasycznej na Uniwersytecie w Poznaniu 2919-2019, red. E. Wesołowska - P. Urbański, Poznań: Wydawnictwo Naukowe UAM, 2019.

Appel W., Zagadka syren. Filologa peregrynacje od antyku po wspótczesność, Toruń: Wydawnictwo Naukowe UMK, 2017.

Apokryfy Nowego Testamentu, tom 1, część 1 i 2: Ewangelie apokryficzne, red. M. Starowieyski, wyd. 2, Kraków: Wydawnictwo WAM, 2017.

Apokryfy Nowego Testamentu, tom 2, część 1 i 2: Apostolowie, red. M. Starowieyski, wyd. 2, Kraków: Wydawnictwo WAM, 2017.

Apokryfy Nowego Testamentu, tom 3: Listy i apokalipsy chrześcijańskie. Apokryfy syryjskie, red. M. Starowieyski, wyd. 2, Kraków: Wydawnictwo WAM, 2017.

Dla dobra Jego Ciała, którym jest Kościót (Kol 1,24). Księga Pamiątkowa Księdza Profesora Antoniego Paciorka z okazji Złotego Jubileuszu Kapłaństwa, red. G.M. Baran, Częstochowa: Edycja Świętego Pawła, 2019.

Duch Święty, Źródto Wody Żywej, red. P. Łabuda, Tarnów: Wydawnictwo Biblos, 2017.

Ideat $i$ antyideat kobiety w literaturze greckiej i rzymskiej, red. A. Marchewka, Gdańsk:

Wydawnictwo Uniwersytetu Gdańskiego, 2018.

Hellenizm a chrześcijaństwo w późnej starożytności i w średniowieczu, red. A. Palusińska, Lublin: Wydawnictwo KUL, 2017.

Kościót. Narodziny Kościoła i rozwój eklezjologii chrześcijańskiej, red. P. Łabuda, Tarnów: Wydawnictwo Biblos, 2018.

Longosz S., Opera Minora Selecta, red. J. Iluk - W. Stawiszyński, Warszawa: Wydawnictwo Naukowe Sub Lupa, 2019.

Magia Ksiag - Księgi Magii. Księga Jubileuszowa poświęcona Profesor Irenie Fijałkowskiej-Janiak, red. D. Oboleńska - U. Patocka-Sigłowa, Gdańsk: Wydawnictwo Uniwersytetu Gdańskiego, 2017.

Nadzieje upadającego świata. Nadzieja w chrześcijańskiej epistolografii tacińskiej IV i V wieku (Ambroży, Augustyn, Hieronim, Paulin z Noli), red. M. Wysocki - J. Pałucki - M. Pyzik-Turska, Lublin: Wydawnictwo KUL, 2019.

Naumowicz J., (red.), Voicu S.J., Przed Żłóbkiem. Magowie i pasterze w tradycji antycznej, BOK, Kraków: Wydawnictwo m, 2019.

Niebo. Tradycje, przekazy, inspiracje, red. S. Konarska-Zimnicka - P. Tambora - B. Wojciechowska, Kielce: Wydawnictwo Jedność, 2017.

Nowe odczytanie codzienności. Codzienność widziana w świetle Jezusa Chrystusa w pierwszych wiekach chrześcijaństwa. Teksty wschodnich i zachodnich Ojców Kościoła. Wybór dokonany przez Wspólnotę Monastyczną z Bose (Italia) według rytmu Liturgii Godzin, tt. A. Koprowski, Warszawa: Wydawnictwo KONTRAST, 2017.

Nowy stownik teologii biblijnej, red. H. Witczyk, Lublin: Towarzystwo Naukowe KUL Kielce: Wydawnictwo Jedność, 2017. 
Nowy Słownik Wczesnochrześcijańskiego Piśmiennictwa, M. Starowieyski - J.M. Szymusiak, Wydanie drugie przepracowane i uzupełnione, przygotował M. Starowieyski przy współpracy W. Stawiszyńskiego, Poznań: Wydawnictwo Św. Wojciecha, 2018.

Ojcowie Kościoła komentują Biblię, Nowy Testament, tom Ib, Ewangelia wedtug św. Mateusza 14-28, wydanie polskie tomu przygotował T. Skibiński SAC, Ząbki: Wydawnictwo Apostolicum, 2018.

Ojcowie Kościoła o Eucharystii, red. P. Wygralak, Teologia Patrystyczna 14, Poznań 2017.

Post jako praktyka duchowa. Ojcowie Kościoła o poście. Przekł. zbiorowy. Wstęp, wybór i oprac. L. Nieścior, BOK, Kraków: Wydawnictwo m, 2019.

Przemoc w świecie starożytnym. Źródła - struktura - interpretacje, red. D. Słapek I. Łuć, Lublin: Wydawnictwo UMCS, 2017.

Pszczoły, miód, wosk pszczeli w symboliczno-metaforycznych obrazach. Od Biblii poprzez antyk do liturgii Kościoła, red. I. Wieżel - G.M. Baran, Kraków: Wydawnictwo „scriptum”, 2018.

Rzymianie i barbarzyńcy. Religia-polityka-kultura, Materiały V Kongresu Mediewistów Polskich, tom 5, red. T. Wolińska - M. Ożóg - K. Kollinger, Rzeszów: Wydawnictwo Uniwersytetu Rzeszowskiego, 2019.

Rzymski Zachód od Augusta do upadku Cesarstwa, Studia poświęcone pamięci Profesora Tadeusza Kotuli w 10 rocznicé śmierci, red. M. Pawlak, Kraków: Towarzystwo Wydawnicze „Historia Iagellonica”, 2017.

Sakramenty Kościoła. Sakramenty uzdrowienia. Sakramenty w stużbie komunii, red. P. Łabuda, Źródło Wody Żywej 6b, Tarnów: Wydawnictwo Biblos, 2019.

Sakramenty Kościoła. Sakramenty wtajemniczenia chrześcijańskiego, red. P. Łabuda, Źródło Wody Żywej 5b, Tarnów: Wydawnictwo Biblos, 2019.

Starowieyski M., WST 2017 (numer specjalny dedykowany ks. prof. dr. hab. Markowi Starowieyskiemu z okazji nadania godności doktora honoris causa Papieskiego Wydziału Teologicznego w Warszawie).

Teologiczne podstawy kultu Chrystusa jako Króla, red. J. Grzywaczewski, Warszawa: Wydawnictwo Naukowe UKSW, 2018.

Wzory kultury antycznej. Reguly zachowania starożytnych Greków $i$ Rzymian, red. J. Doroszewska - M. Job - T. Sapota, Katowice: Wydawnictwo Uniwersytetu Śląskiego, 2018.

W kręgu antycznych politei. Księga Jubileuszowa ofiarowana Profesorowi Janowi Ilukowi, red. W. Gajewski - I. Milewski, Gdańsk: Wydawnictwo Uniwersytetu Gdańskiego, 2017.

Ziemia obiecana. Panta rhei-pamięć, czas i przemijanie w starożytności, red. D. Lewandowska, Warszawa: Wydawnictwo Sub Lupa, 2017.

Żywe pochodnie. Rozmowy o początkach Kościoła prowadzi Maciej Müller, Poznań: Wydawnictwo W drodze, 2018. 


\section{Bibliografie i problemy metodologiczne}

Baran G.M., Spis publikacji ks. prof. dr hab. Antoniego Paciorka, w: Dla dobra Jego ciała, którym jest Kościót (Kol 1, 24) [1], s. 65-78.

Drączkowski F., Metoda wykresograficzna (wykresografia) w stużbie teologii, VoxP 67 (2017) s. 115-131.

Figiel J., Polska bibliografia antyku chrześcijańskiego 2015-2016, VoxP 68 (2017) s. 715-789.

Gołda A. - Tałuć K., Materiały źródłowe do biografii naukowej ks. prof. Wincentego Myszora (katalog z opracowaniem), Katowice: Fundacja Centrum Badań nad Historią Kościoła im. Ks. Wincentego Myszora - Księgarnia św. Jacka, 2020.

Groch R., Ks. prof. dr hab. Antoni Żurek-curriculum vitae i dorobek naukowo-dydaktyczny, TST 37/1-2 (2018) s. 9-30.

Grzywaczewski J., Les elements patrisique dans la Lettre encyclique du Pape Jean-Paul II «l'Église vit de l'Eucharistie», „E-Patrologos” 4/1 (2019) s. 104-117.

Grzywaczewski J. - Nieścior L., Marek Eremita: biografia i bibliografia, CT 89/1 (2019), s. 5-14.

Kalinkowski S., Śp. Ks. prałat Kazimierz Obrycki (1941-2019), VoxP 72 (2019) s. 353-357.

Kamczyk W., Patrystyka w ,Śląskich Studiach Historyczno-Teologicznych” (1968-2016), SSHT 50/2 (2017) s. 374-383.

Kochanek P., Statystyczno-porównawcza analiza XXIII Międzynarodowego Kongresu Bizantynologicznego (Belgrad, 22-27 VIII 2016), VoxP 67 (2017) s. 241-257.

Kozłowski M., Wincenty Myszor (22 V 1941-19 II 2017) - badacz antyku chrześcijańskiego, „Nowy Filomata” 21/1 (2017) 141-143.

Kozłowski M., Profesor Maria Dzielska (18 IX 1942 - 30 VII 2018), „Nowy Filomata” 22/2 (2018) s. 157-158.

Longosz S., Doktor Robert Sawa (18 II 1966 - 24 II 2018). Ttumacz pism wczesnochrześcijańskich, VoxP 70 (2018) s. 823-836.

Longosz S., Ks. Prof. Wincenty Myszor (22 V 1941 - 19 II 2017). Polski odkrywca gnozy wczesnochrześcijańskiej, VoxP 68 (2017) s. 843-856.

Longosz S. - Figiel J., Bibliografia prac drukowanych Ks. Prof. Stanisława Longosza, w: Longosz S., Opera Minora Selecta [1], s. 19-39.

Milewski I., Bibliografia prac Profesora Iluka, w: W kregu antycznych politei [1], s. 33-46.

Milewski I., Profesor Jan Iluk, w: W kregu antycznych politei [1], s. 21-32.

Nieścior L., Wybrana bibliografia na temat miłości w nauce św. Augustyna, „E-Patrologos" 3/4 (2017) s. 50-56.

Pawlina K., Honoris Causa-Ks. prof. Marek Starowieyski. Warszawa 12 XII 2017, WST 31/2 (2018) s. 7-8.

Pietras H., Patrologia in „, Gregorianum”, „Gregorianum” 100/4 (2019) s. 765-775.

Przepióra M., Bibliografia drukowanych prac Ks. Prof. dra hab. Bogdana Częsza, VoxP 67 (2017) s. 31-40. 
Stawiszyński W., Bibliografia Patrystyczna 1901-2016. Polskie ttumaczenia tekstów starochrześcijańskich pierwszego tysiąclecia. Wydanie trzecie rozszerzone, poprawione i zmienione, Kraków: Wydawnictwo TYNIEC, 2017.

Szczur P., Bibliografia drukowanych prac Doktora Stanisława Kalinkowskiego, VoxP 69 (2018) s. 27-37.

Szczur P., Dr Stanisław Kalinkowski: Curriculum vitae, VoxP 69 (2018) s. 25-26.

Szczur P., Degórski Bazyli Remigiusz Stefan OSPPE, w: Encyklopedia 100-lecia KUL, t. 1, red. E. Gigilewicz et al., Lublin: Wydawnictwo KUL, 2018, s. 151-152.

Szczur P., Ks. Profesor Franciszek Draczkowski (26 IV 1941 - 15 III 2018). Niestrudzony propagator myśli Ojców Kościoła, VoxP 70 (2018) s. 837-842.

Szczur P. - Walkusz J., Institute of Church History and Patrology, w: One Hundred Years of Theology at the John Paul II Catholic University of Lublin, red. S. Nowosad J. Mastej, Lublin: Wydawnictwo KUL, 2019, s. 47-68.

Szczur P., Instytut Historii Kościoła i Patrologii, w: 100 lat teologii na KUL, red. S. Nowosad - J. Mastej, Lublin: Wydawnictwo KUL, 2018, s. 43-61.

Szczur P., Prace Instytutu Historii Kościoła, w: Encyklopedia 100-lecia KUL, t. 2, red. E. Gigilewicz et al., Lublin: Wydawnictwo KUL, 2018, s. 217.

Szczur P., Studia historyczne, w: Encyklopedia 100-lecia KUL, t. 2, red. E. Gigilewicz et al., Lublin: Wydawnictwo KUL, 2018, s. 398.

Szczur P., Szczur Piotr, w: Encyklopedia 100-lecia KUL, t. 2, red. E. Gigilewicz et al., Lublin: Wydawnictwo KUL, 2018, s. 427-428.

Szerszeń M.T., Wybrane publikacje z dziedziny antyku i tradycji antycznej wydane $w$ latach 2016-2017, „Nowy Filomata” 21/2 (2017) s. 285-295.

Szerszeń M.T., Wybrane publikacje z dziedziny antyku i tradycji antycznej wydane $w$ latach 2017-2018, „Nowy Filomata” 22/2 (2018) s. 197-207.

Tałuć K., (wstęp i edycja), Materiały źródłowe do biografii naukowej ks. prof. Wincentego Myszora (Wybór korespondencji), Katowice: Fundacja Centrum Badań nad Historią Kościoła im. Ks. Wincentego Myszora - Księgarnia św. Jacka, 2019.

Turek W., Laudacja na cześć Ks. prof. Marka Starowieyskiego (Warszawa 12 XII 2017), WST 31/2 (2018), s. 9-16.

Widok N., Karl Holl (1866-1926) - luterański badacz źródeł patrystycznych, VoxP 71 (2019) s. 505-529.

Wygralak P., Ksiadz dr hab. Antoni Swoboda, prof. UAM. Curriculum vitae, VoxP 71 (2019) s. 17-22.

Wygralak P., Bibliografia prac naukowych ks. dr. hab. Antoniego Swobody, VoxP 71 (2019) s. 15-16.

Wygralak P., Ks. Prof. dr hab. Bogdan Częsz: «curriculum vitae», VoxP 67 (2017) s. 27-29.

Wysocki M., Bober Andrzej, w: Encyklopedia 100-lecia KUL, t. 1, red. E. Gigilewicz et al., Lublin: Wydawnictwo KUL, 2018, s. 67-68. 


\section{Prace ogólne, historie literatury}

Adamiak S., Dawniej prześladowania, dzisiaj dialog?, „Więź” 674/4 (2018) s. 161-168.

Adamiak S., Roma locuta, causa finita? Nie zawsze, „Więź” 678/4 (2019) s. 106-114.

Bider S., «Utrum sexus femineus impediat ordinis susceptionem». Niezdolność kobiet do przyjęcia święceń diakonatu $w$ Kościele tacińskim $w$ ujęciu historyczno-prawnym, TSS 14 (2017) s. 247-274.

Bralewski S., Cesarzowa Helena, matka Konstantyna Wielkiego w ujęciu Sokratesa z Konstantynopola i Hermiasza Sozomena, w: W kregu antycznych politei [1], s. 49-57.

Chłopowiec M., Pokutna «peregrinatio» we wczesnym średniowieczu, VoxP 69 (2018) s. 83-103.

Cholewa M. - Gilski M., Dziedzictwo Soborów, Kraków: Wydawnictwo „scriptum”, 2019.

Cholewa M. - Gilski M., Wykład 150 Ojców z Konstantynopola. Komentarz lingwistyczno-pastoralny, Kraków: Wydawnictwo „scriptum”, 2018.

Curtius E.R., Literatura europejska i łacińskie średniowiecze, tł. i opr. A. Bobrowski, Kraków: Wydawnictwo UNIVERSITAS, Kraków 2018.

Degórski B., Syntetyczne ujęcie okresu patrystycznego, „Dissertationes Paulinorum” 28 (2019) s. 5-68.

Dzwon w chrześcijańskiej Europie, red. G. Guźlak, Bydgoszcz: Wydawnictwo Uniwersytetu Kazimierza Wielkiego, 2017.

Ehmig U. - Zawadzki F., Anathema in lateinischen Inschriften, VoxP 71 (2019) s. 185-207.

Fijołek U., Kosmos - sfery niebieskie i ich mieszkańcy oczami starożytnych oraz pisarzy chrześcijańskich, w: Niebo. Tradycje, przekazy, inspiracje [1], s. 189-202.

Gacia T., Antibarbarus sive de laudibus Georgii praeclari Latinitatis in Polonia cultoris dissertatiuncula brevis, Certamen Latinum Salesianum 1, red. M. Pisini-M. Sajovič, Roma 2018, s. 79-85.

Gilski K. - Cholewa M., Język soborów pierwszego tysiąclecia, Kraków: Wydawnictwo scriptum, 2018.

Heszen A., Polihymnia chrześcijańska. Poetyka i morfologia greckich hymnów III-V w., Kraków: Wydawnictwo UJ, 2019.

Jundziłł J., Powtórne $i$ wielokrotne matżeństwa chrześcijan z Rzymu III-VI wieku, w: Wregu antycznych politei [1], s. 155-176.

Kochanek P., Wpływ starożytnej schematyzacji mnemotechnicznej na kartografię średniowieczna i wczesnonowożytna, VoxP 69 (2018) s. 285-375.

Kołoczek B.J., Historia w rzymskiej literaturze erudycyjnej. Od Warrona do Kasjodora, Kraków: Towarzystwo Wydawnicze Historia Iagiellonica, 2019.

Kowalski M., How Oral Was Ancient Literature? The Case of Pauline Letters, w: Nadzieje upadajacego świata. Nadzieja w chrześcijańskiej epistolografii łacińskiej IV i V wieku (Ambroży, Augustyn, Hieronim, Paulin z Noli), red. M. Wysocki - J. Pałucki - M. Pyzik-Turska, Lublin: Wydawnictwo KUL, 2019, s. 61-85. 
Kozłowski J.M., Brzeg morza jako miejsce odprężenia $i$ wypoczynku w literaturze antycznej. Od Homera do Ojców Kościoła, „Meander” 73 (2018) s. 3-19.

Królikowski J., Początki chrześcijańskiego tekstu Pisma Świętego, VoxP 67 (2017) s. 259-276.

Królikowski J., Początki Pism chrześcijańskich, w: Dla dobra Jego ciała, którym jest Kościół (Kol 1, 24) [1], s. 207-222.

Leśniewski K., Geneza chrześcijańskiej postugi hospicyjnej, VoxP 67 (2017) s. 289-301.

Lewandowska D., Androgyn czy hermafrodyta? Studium nad hermafrodytyzmem w źródłach antycznych, Warszawa: Wydawnictwo Naukowe Sub Lupa, 2019.

Longosz S., Chrześcijańskie widowiska zastępcze w propozycji Ojców Kościoła, VoxP 67 (2017) s. 303-360.

Mejzner M., Wczesnochrześcijańskie wierzenia millenarystyczne jako specyficzny wyraz eschatologicznej nadziei, w: Nadzieje upadającego świata. Nadzieja w chrześcijańskiej epistolografii łacińskiej IV i V wieku (Ambroży, Augustyn, Hieronim, Paulin z Noli), red. M. Wysocki - J. Pałucki - M. Pyzik-Turska, Lublin: Wydawnictwo KUL, 2019, s. 175-197.

Milewski I., „Panis et vinum”. Einige Bemerkungen zu den Lebensmittelpreisen und Ernährungsgewohnheiten des spätantiken Menschen bei den griechischen und lateinischen Kirchenvätern, w: W kregu antycznych politei [1], s. 262-275.

Muszala A. - Woźniak R., Ojcowie naszej wiary, Kraków: Wydawnictwo WAM, Fundacja PUSTELNIA.PL, 2019.

Muszyński M., Siła, norma, idea. Prawo międzynarodowe w ujęciu historycznym, tom 1, Warszawa: Wydawnictwo Naukowe UKSW, 2019.

Niepsuj Ł., Patrystyczny przedsiębiorca. Pojęcie działania przedsiębiorczego $w$ świetle pism wybranych pisarzy wczesnochrześcijańskich, TST 37/1-2 (2018) s. 47-74.

Nieścior L., Post w czasach ojców Kościoła, w: Post jako praktyka duchowa. Ojcowie Kościoła o poście [1], s. 11-52.

Nieścior L., Profetyzm i apostolat Maryi z perspektywy pierwszych wieków, „Lumen Gentium. Zeszyty Misjologiczne" 38/1 (2018) s. 30-45.

Olszaniec Sz., Matzeństwo i rodzina w ustawodawstwie kierowanym do prefektów "praetorio» Italii, Illyrikum i Afryki, w: W kregu antycznych politei [1], s. 276-290.

Paczkowski M.C., Wczesnochrześcijańskie rozważania o imieniu Jezus, PST 33 (2018) s. $129-162$.

Paczkowski M.C., Wieczernik jako miejsce ustanowienia Eucharystii w źródłach wczesnochrześcijańskich, w: Ojcowie Kościoła o Eucharystii, red. P. Wygralak, Teologia Patrystyczna 14, Poznań: Wydział Teologiczny, 2017, s. 43-84.

Piasecki D., Eucharystia u Homera?, VoxP 69 (2018) s. 561-572.

Piątek M., Chrześcijańskie zagadnienia protologiczno-eschatologiczne wyrażone za pomoca pogańskich liter. Na podstawie centonu «De Verbi Incarnatione», RT 66/4 (2019) s. 5-20.

Podbielski H. (red.), Literatura Grecji starożytnej, t. 1-2, Lublin: Towarzystwo Naukowe KUL, 2018 (wznowienie wydania z 2005 roku). 
Przyszychowska M., Czy «O definicjach»(Liber de definitionibus) Pseudo-Atanazego $z$ Aleksandrii to II rozdziat «Przewodnika» (Viae dux) Anastazegoz Synaju?, „E-Patrologos" 4/1 (2019) s. 50-92.

Radzik Z., Emancypantki. Kobiety, które zbudowaty Kościót, Kraków: Wydawnictwo WAM, 2018.

Scheiwiller J., Zarzuty pogańskie przeciwko chrystianizmowi. Apologia wiary w pierwszych wiekach, Sandomierz: Wydawnictwo Armoryka, Sandomierz 2017 (przedruk z: „Homiletyka”. Pismo miesięczne poświęcone kaznodziejstwu i życiu duchownemu, pod kierunkiem literackim Ks. Mariana Nassalskiego Magistra Teologii. Rok siódmy. - Tom XII. Włocławek. Redakcja i Administracja „Homiletyki”. 1904, s. 557-571. Tom XIII. Włocławek 1904, s. 7-17; 215-229).

Siwicka M. Symbolika pszczoty i miodu w greckich tekstach patrystycznych, w: Pszczoty, miód, wosk pszczeli w symboliczno-metaforycznych obrazach. Od Biblii poprzez antyk do liturgii Kościoła, red. I. Wieżel - G.M. Baran, Kraków: Wydawnictwo scriptum, 2018, s. 143-195.

Sowińska A., Hermetica średniowieczna i renesansu. Studium z historii myśli europejskiej, Katowice: Wydawnictwo Uniwersytetu Śląskiego, 2018.

Sprutta J., Wczesnochrześcijańskie uczty w I-III w.: szkic, „Nowy Filomata” 22/2 (2018) s. $129-138$.

Starowieyski M., Nowe spotkania i wędrówki, Kraków: Wydawnictwo PETRUS, 2018.

Starowieyski M., Ojcowie Kościoła i starożytne Sobory, Kraków: Wydawnictwo PETRUS, 2019.

Szczur P., Kerygmat jako metoda i treść misji Kościoła w nauczaniu i praktyce pisarzy wczesnochrześcijańskich, w: Misja: istota i chwała Kościoła katolickiego, red.

A.A. Napiórkowski, Cracoviensis cogitatio Ecclesiae 10, Kraków 2019, s. 41-61.

Szram M., The Time of the Mission of Christ in the Light of the Spiritual Meaning of Numbers in the Alexandrian Allegorical Exegesis, w: Tempo di Dio, tempo dell'uomo. XLVI Incontro di Studiosi dell'Antichità Cristiana (Roma, 10-12 V 2018), red. M. Ghilardi, Studia Ephemerides Augustinianum 155, Roma - Lugano: Institutum Patristicum Augustinianum, 2019, s. 233-239.

Turek W., Jakimi językami postugiwali się starożytni chrześcijanie Afryki Pólnocnej? Analiza odnośnych tekstów Tertuliana, św. Cypriana i św. Augustyna, VoxP 72 (2019) s. 27-48.

Wasyl A.M., Alcestis Barcelońska oraz Centon Alcesta. Późnoantyczne spojrzenie na mit i gatunek, Kraków: Wydawnictwo UJ, 2018.

Wojcieszak M., Kilka uwag na temat praktyk magicznych chrześcijan w późnoantycznych tekstach normatywnych, Spelp 52 (2018) s. 421-434.

Wysocki M., Chrześcijańska nadzieja w listach konsolacyjnych (św. Ambroży, św. Augustyn, św. Hieronim, św. Paulin), w: Nadzieje upadajacego świata. Nadzieja w chrześcijańskiej epistolografii łacińskiej IV i V wieku (Ambroży, Augustyn, Hieronim, Paulin z Noli), red. M. Wysocki - J. Pałucki - M. Pyzik-Turska, Lublin: Wydawnictwo KUL, 2019, s. 217-234. 
Wysocki M., How to Measure the Time of God and the Time of Men? Study of the Letters of Ambrose and Augustine, w: Tempo di Dio, tempo dell'uomo. XLVI Incontro di Studiosi dell'Antichità Cristiana (Roma, 10-12 V 2018), red. M. Ghilardi, Studia Ephemerides Augustinianum 155, Roma - Lugano: Institutum Patristicum Augustinianum, 2019, s. 441-449.

Wysocki M., Przesyłam ten list przez ręce mojego umiłowanego... czyli rzecz o kurierach w listach chrześcijańskich, w: Nadzieje upadającego świata. Nadzieja w chrześcijańskiej epistolografii łacińskiej IV i V wieku (Ambroży, Augustyn, Hieronim, Paulin z Noli), red. M. Wysocki - J. Pałucki - M. Pyzik-Turska, Lublin: Wydawnictwo KUL, 2019, s. 113-123.

Wysocki M. - Pyzik-Turska M., O listach w listach Ojców Kościoła, w: Nadzieje upadającego świata. Nadzieja w chrześcijańskiej epistolografii łacińskiej IV $i$ V wieku (Ambroży, Augustyn, Hieronim, Paulin z Noli), red. M. Wysocki - J. Pałucki - M. Pyzik-Turska, Lublin: Wydawnictwo KUL, 2019, s. 87-112.

Żelazny J., Koncepcja czasu w chrześcijaństwie orientalnym, VV 35 (2019) s. 419-433.

Żurek A., Jak rozumieć znaki zodiaku? - radza Ojcowie Kościoła, w: Niebo. Tradycje, przekazy, inspiracje [1], s. 31-45.

Żurek A., Inicjacja wczesnochrześcijańska: katechumen-chrześcijanin-wierny, „Studia Theologica Grodnensia” 11 (2017) s. 29-44.

\section{Historia wspólnot, instytucji, okresów historycznych, regionów}

Adamiak S. Deo laudes. Historia sporu donatystycznego, Parnassus 11, Warszawa: Wydawnictwo Naukowe Sub Lupa, 2019.

Adamiak S., Diakoni w Kościele późnej starożytności-niektóre zagadnienia, w: Diakonat stały $w$ Kościele $w$ Polsce. Historia - teologia - wyzwania, red. W. Rozynkowski, Pelplin 2019, s. 15-24.

Adamiak S., I figli dei chierici nella legislazione dei concili occidentali nel IV e V secolo, w: Il bambino nelle fonti Cristiane. XLV Incontro di Studiosi dell'Antichità Cristiana (Roma, 11-13 05 2017), red. M. Ghilardi, Studia Ephemeridis Augustinianum 154, Roma - Lugano: Institutum Patristicum Augustinianum, 2019, s. 219-225.

Adamiak S., Who was rebaptized by the Donatists, and why?, ,Journal of Late Antiquity” 12/1 (2019) s. 46-64.

Augustyniak Z., Ewolucja instytucji małzeństwa w świetle etiopskich kodeksów prawnych, Warszawa: Dom Wydawniczy Elipsa, 2018.

Bastit-Kalinowska A., «Aquileienses clerici quasi chorus beatorum habentur» (Hieronim, Kronika, rok 374). Przykład życia religijnego duchownych pod koniec IV wieku, VoxP 70 (2018) s. 205-215. 
Bralewski S., Symmachia cesarstwa rzymskiego z Bogiem chrześcijan (IV-VI wiek), tom 1: «Niezwykła przemiana» - narodziny nowej epoki, Byzantina Lodziensia 27, Łódź: Wydawnictwo Uniwersytetu Łódzkiego, 2019.

Bralewski S., Symmachia cesarstwa rzymskiego z Bogiem chrześcijan (IV-VI wiek), tom 2: Jedna religia w jednym cesarstwie. Rzymscy imperatorzy sprzymierzeni z Bogiem na straży jedności Kościoła od Konstantyna I do Justyniana I, Byzantina Lodziensia 32, Łódź: Wydawnictwo Uniwersytetu Łódzkiego, 2019.

Ciecieląg J., Kontakty Heroda Wielkiego z diaspora żydowska - fakt czy mit?, w: W kręgu antycznych politei [1], s. 74-80.

Czyżewski B., Herezje wczesnochrześcijańskie - zagadnienia wprowadzające, VoxP 68 (2017) s. 7-20.

Czyżewski B., ,Reguła Mistrza” o wyborze i nauczaniu opata, VoxP 70 (2018) s. 243-258.

Czyżewski B., Reguły iberyjskie o starcach i chorych w klasztorze, „Życie konsekrowane” 139/5 (2019) s. 45-57.

Czyżewski B., Wskazania dla mnichów w komentarzu do Modlitwy Pańskiej w „Regule Mistrza”, VoxP 69 (2018) s. 143-154.

Czyżewski B. - Kieling M. - Wygralak P., Praktyczne wskazania dla duchownych w literaturze patrystycznej $i$ w prawodawstwie synodalnym, Teologia Patrystyczna 15, Poznań: Uniwersytet im. Adama Mickiewicza, Wydział Teologiczny, 2018.

Degórski B., Hierarchia Kościoła pierwszych wieków. Opracowanie szkicowe, w: Wyjątkowość Kościoła katolickiego, red. A.A. Napiórkowski, Cracoviensis Cogitatio Ecclesiae 9, Kraków: Uniwersytet Papieski Jana Pawła II, 2018, s. 9-33.

Dopierała K., Księga papieży, Poznań: Wydawnictwo Zysk i S-ka, 2019.

Dumézil B., Królowa Brunhilda, tł. K. Antkowiak, Kęty: Wydawnictwo Marek Derewiecki, 2018.

Filipczak P., Administracja cesarska w Syrii za panowania Dioklecjana i Konstantyna Wielkiego-problem utworzenia prowincji Eufratenzja, w: W kręgu antycznych politei [1], s. 106-116.

Gajewski W., Początki diaspory żydowskiej w Rzymie, w: W kręgu antycznych politei [1], s. $117-133$.

Hołasek A.R., Obraz życia codziennego chrześcijan na Wschodzie w świetle kościelnych źródet normatywnych (IV-V wiek) (Dysertacja doktorska przygotowana w Katedrze Historii Bizancjum Uniwersytetu Łódzkiego pod kierunkiem dr. hab. Teresy Wolińskiej, prof. UŁ, Łódź 2018 - publikacja internetowa).

Karczewski Ł., Męczeństwo za wiare garnizonu z Gazy w okresie wczesnych podbojów muzułmańskich w świetle "Opisu męczeństwa sześćdziesięciu męczenników z Gazy», SaeCh 24 (2017) s. 28-38.

Kasperski R., Reges et gentes. Studia nad dyskursem legitymizującym władzę nad wspólnotami wyobrażonymi oraz strategiami ich konstruowania we wczesnym średniowieczu (VI-VII w.), Warszawa: Instytut Historii PAN, 2017. 
Kasprzak D., Polityka wyznaniowa w katolickim Królestwie Wizygotów w latach 586-711, w: Rzymianie i barbarzyńcy [1], s. 189-210.

Królikowski J., IV Sobór Konstantynopolitański (869-870) i obrazy, w: Święte wizerunki w przekazie Dobrej Nowiny, red. N. Widok, Opolska Biblioteka Teologiczna 161, Opole: Redakcja Wydawnictw Wydziału Teologicznego Uniwersytetu Opolskiego, 2017, s. 59-74.

Krawczuk M., Rotu'a Haymanot, «Kazanie o Chrzcie Chrystusa» z rękopisu EMML 7028 f. 6v-20r a postrzeganie islamu, PrzOr 269/1 (2019) s. 37-47.

Leska A., W kręgu problematyki stosunków Kościoła i państwa w świecie późnego antyku, VoxP 67 (2017) s. 277-288.

Lipoński W., Narodziny cywilizacji Wysp Brytyjskich, wyd. 4, Poznań: Wydawnictwo Poznańskie, 2017.

Misiarczyk L., Status Żydów w Cesarstwie Chrześcijańskim według Księgi XVI Kodeksu Teodozjusza - cz. I, „Seminare” 40/2 (2019) s. 175-189.

Misiarczyk L., Terapeuci-̇̇ydowscy prekursorzy monastycyzmu chrześcijańskiego $w$ „,De vita contemplativa" Filona z Aleksandrii, VoxP 70 (2018) s. 9-23.

Modzelewski K., Studia wybrane z dziejów społeczeństwa, prawa i ustroju Europy wczesnośredniowiecznej, Warszawa: Wydawnictwa Uniwersytetu Warszawskiego, 2018.

Nelson J.L., Karol II Łysy, tł. G. Smółka, Oświęcim: Wydawnictwo Napoleon V, 2017.

Niewiadomska M., Chrystianizacja Gruzji wedtug «Historii Kościelnej» Rufina z Akwilei, SaeCh 26/1 (2019) s. 15-24.

Ożóg M., Rozporządzenia prawne Teoderyka Wielkiego $w$ kwestiach religijnych $w$ «Variae» Kasjodora, w: Rzymianie i barbarzyńcy [1], s. 169-188.

Paczkowski M., Symbolika eklezjalna Jerozolimy a polemika antydonatystyczna w Afryce Rzymskiej, VoxP 72 (2019) s. 171-202.

Papandrea J.L., Jak Kościót Katolicki zachował autentyczna doktrynę wczesnych chrześcijan, tł. M. Król, Kraków: Wydawnictwo eSPe, 2017.

Piechocka-Kłos M., Przedstawiciele zawodów scenicznych w świetle dokumentów wczesnochrześcijańskich synodów (IV-V w.), „Studia Nauk Teologicznych PAN” 14 (2019) s. 89-102.

Pietras H., La genesi delle indulgenze, „Gregorianum” 99/2 (2018) s. 315-335.

Pietras H., Geneza odpustów, „Theologica Wratislaviensia” 12 (2017) s. 17-28.

Pietras H., Herezje, Kraków: Wydawnictwo WAM, 2019.

Pigoński Ł., Polityka zachodnia cesarzy Marcjana (450-457) i Leona I (457-474), Byzantina Lodziensia XXIX, Łódź: Wydawnictwo Uniwersytetu Łódzkiego, 2019.

Puchała K., Apostolskie świadectwo rzymskich męczenniczek, „E-Patrologos” 4/1 (2019) s. 17-31.

Rosik M., Synagoga a rodzący się Kościół w perspektywie misji, w: Misja: istotą i chwała Kościoła katolickiego, red. A.A. Napiórkowski, Cracoviensis cogitatio Ecclesiae 10, Kraków 2019, s. 9-21. 
Sadurska K., Między Rzymem a opozycja antychalcedońska. Zasadnicze kierunki polityki religijnej cesarza Leona I (457-474), VoxP 71 (2019) s. 423-446.

Skibiński T., Między praktyka św. Ambrożego z Mediolanu a prawodawstwem cesarza Honoriusza. Przyczynek do historii wykupu jeńców w Zachodnim Cesarstwie Rzymskim, w: Społeczeństwo, historia, sztuka. Księga na 30-lecie Wydziału Nauk Historycznych i Społecznych UKSW w Warszawie, red. A. Czyż, Warszawa: Wydawnictwo Naukowe UKSW, 2017, s. 237-247.

Skibiński T., «Necator pauperum» $i$ «necator egentium»w prawodawstwie synodów galijskich V-VII wieku, VoxP 67 (2017) s. 543-554.

Skibiński T., Obraz barbarzyńców $w$ Cesarstwie Rzymskim w źródłach łacińskich lat 376-476, Warszawa: Wydawnictwo Naukowe UKSW, 2018.

Skwierczyński K., Wino i grzech, czyli Piotra Damianiego traktat o wodzie i abstynencji, PHis 108/2 (2017) s. 441-448.

Smorczewski Ł., Administracja diecezji Pontu w późnym Cesarstwie Rzymskim, Poznań: Instytut Historii UAM, 2019.

Starowieyski M., Nasi bracia chrześcijanie Wschodu, Kielce: Wydawnictwo Jedność, 2019.

Strękowski S., Synody w Afryce Prokonsularnej III wieku jako przejaw kolegialności biskupów w świetle «Kanonów synodalnych» $i$ «Listów» św. Cypriana, VoxP 72 (2019) s. 97-120.

Strzelczyk J., „, Arianizm” jako religijna alternatywa u ludów germańskich na przełomie starożytności i średniowiecza, w: Recepcja i odrzucenie. Kontakty międzykulturowe w średniowieczu, Materiały V Kongresu Mediewistów Polskich 1, red. L. Słupecki - P. Sierżęga - A. Rozwałka - M. Dzik, Rzeszów: Wydawnictwo Uniwersytetu Rzeszowskiego, 2018, s. 151-166.

Szczur P., Czy Chrystus narodzit się 25 grudnia?, „Głos Katolicki” - „Voix Catholique” 59/45; 24-31.12.2017 (2017) s. 7.

Szczur P., Kolekty zwyczajne i nadzwyczajne jako źródła środków na jałmużnę biskupia (do IV wieku). Zarys problematyki, „Res Historica” 44 (2017) s. 11-31.

Szram M., Mesalianie - rygorystyczny ruch ascetyczny czy herezja doktrynalna?, RT 65/4 (2018) s. 15-28.

Śrutwa J., Dzieje Kościoła w starożytności, t. 1-2, Lublin: Towarzystwo Naukowe KUL, 2018. Widok N., Instytucja matżeństwa w pismach okresu poapostolskiego i apologetów II w., w: Sakramentalna przysięga matżeńska w obliczu wyzwań współczesnego świata, red. P. Landwójtowicz - S. Pawiński, Człowiek Rodzina Społeczeństwo 28, Opole: Redakcja Wydawnictw Wydziału Teologicznego Uniwersytetu Opolskiego, 2017, s. 9-25.

Wilczyński M., Droga na szczyt i droga w otchłań - kilka uwag o karierze Flawiusza Stilichona, VoxP 69 (2018) s. 681-705.

Wilczyński M., Germanie w stużbie zachodniorzymskiej w Vw. n.e., Studium prosopograficzne, wyd. 2, Oświęcim: Wydawnictwo Napoleon V, 2018. 
Wilczyński M., Polityka wyznaniowa jako ważny element polityki wewnętrznej i zewnętrznej władców wandalskich i swebskich. Próba porównania, w: Rzymianie i barbarzyńcy [1], s. 149-167.

Wilczyński W., Roma capta! - Uwagi na temat relacji o zdobyciu Rzymu w 410 i 455 r. $w$ dziełach wybranych autorów późnoantycznych, VoxP 70 (2018) s. 311-338.

Wipszycka E., Chrześcijaństwo starożytnego Egiptu, Źródła monastyczne - monografie 7 , Kraków: Wydawnictwo TYNIEC, 2018.

Wipszycka E., Kościół w świecie późnego antyku, wyd. 2, Warszawa: Wydawnictwa Uniwersytetu Warszawskiego, 2017.

Wygralak P., Rola biskupów Rzymu w sporach doktrynalnych starożytnego Kościoła, VoxP 69 (2018) s. 707-719.

Wygralak P., Rola ojców Kościoła w budowaniu społeczeństwa chrześcijańskiego w Afryce Prokonsularnej (I-V wiek), VoxP 72 (2019) s. 7-26.

Wysocki M. - Pałucki J., Nadzieja upadającego świata. Ojcowie Kościoła w swych listach wobec barbarzyńców, w: Nadzieje upadającego świata. Nadzieja w chrześcijańskiej epistolografii łacińskiej IV i V wieku (Ambroży, Augustyn, Hieronim, Paulin z Noli), red. M. Wysocki - J. Pałucki - M. Pyzik-Turska, Lublin: Wydawnictwo KUL, 2019, s. $235-258$.

Żurek A., Eklezjologia wczesnochrześcijańska, w: Kościół. Narodziny i rozwój eklezjologii chrześcijańskiej [1], s. 159-182.

Żurek A., "Jeden, święty, powszechny i apostolski Kościót...», w: Kościót. Narodziny i rozwój eklezjologii chrześcijańskiej [1], s. 155-167.

Żurek A., «Wierzę w Kościót...», w: Kościót. Narodziny Kościoła i rozwój eklezjologii chrześcijańskiej [1], s. 141-153.

\section{Historia doktryn (teologia i filozofia)}

Czyżewski B., Maryja a pokój w nauczaniu Ojców Kościoła zachodniego, „Salvatoris Mater" 20/1-4 (2018) s. 31-43.

Degórski B., Concetto lineare del tempo nel dialogo salvifico di Dio con l'umanità secondo i «Tractatus» di san Gaudenzio di Brescia, w: Tempo di Dio, tempo dell'uomo. XLVI Incontro di Studiosi dell'Antichità Cristiana (Roma, 10-12 V 2018), red. M. Ghilardi, Studia Ephemerides Augustinianum 155, Roma - Lugano: Institutum Patristicum Augustinianum, 2019, s. 357-369.

Górecki P., Ikonoklazm - spór religijny czy polityczny? Leona III idea obrony czystości wiary i uniformizacji państwa, w: Święte wizerunki w przekazie Dobrej Nowiny, red. N. Widok, Opolska Biblioteka Teologiczna 161, Opole: Redakcja Wydawnictw Wydziału Teologicznego Uniwersytetu Opolskiego, 2017, s. 37-58. 
Hadot P., Ćwiczenia duchowe i filozofia starożytna, tł. P. Domański - W. Klenczon, Warszawa: Wydawnictwo Aletheia, 2019.

Jaśkiewicz G., Pelagianizm i neopelagianizm. Współczesne zagrożenia dla człowieka i jego wiary, Paryż - Częstochowa: Częstochowskie Wydawnictwo Archidiecezjalne REGINA POLONIAE, 2019.

Kamiński J., «Praesidium fidei». Dziewictwo Maryi w debacie apologetycznej Ojców Kościoła IV wieku, SACh SN 20, Katowice: Wydział Teologiczny UŚ, 2018.

Kashchuk O., Logos-Sarx Christology and the Sixth-Century Miaenergism, VoxP 67 (2017) s. 197-223.

Kashchuk O., The Promotion of Miaenergism as a Challenge to Identity of Non-Chalcedonian Christiaanity, VoxP 69 (2018) s. 257-283.

Kasprzak D., Kształtowanie się nauki o niebie w teologii patrystycznej I-III wieku, Kraków: Wydawnictwo Naukowe UP Jana Pawła II, 2017.

Koniecko B., Nie żartujcie sobie z Bóstwa! Kontrowersje teologiczne w IV w. dotyczace Ducha Świętego na podstawie «Listów do Serapiona» św. Atanazego oraz dzieła «O Duchu Świętym» św. Bazylego Wielkiego, Kraków: Wydawnictwo TYNIEC, 2019.

Kozłowski J.M., The Christian Martyr as a Hyperthanatic Philosopher and «Mystes», and the Success of Christianity, VoxP 69 (2018) s. 377-391.

Liszka P., Dzieje oddziaływania hellenizmu na chrześcijaństwo, RBL 70/1 (2017) s. 5-25.

Longosz S., Stosunek starożytnych filozofów greckich do życia poczętego (Presokratycy, Platon, Arystoteles, Stoicy), w: W kręgu antycznych politei [1], s. 214-250.

Maspero G., Different Strategies of the Greek Fathers Against the Pneumatomachians, VoxP 68 (2017) s. 193-215.

Mateja L., Chrzest jako misterium pieczęci w tradycji pierwszych trzech wieków, „Polonia Sacra” 23/4 (2019) s. 121-137.

Mrugalski D., «Agnostos Theos»: Relacja między nieskończonościa a niepoznawalnościa Boga w doktrynach medioplatoników, „Roczniki Filozoficzne” 67/3 (2019) s. 25-51.

Mrugalski D., Plato Read Moses and (Mis-) Understood: The Middle Platonic Context in which the "Creatio ex Nihilo» Doctrine Was Devised, ,Studia z historii filozofii” 4/10 (2019) s. 7-30.

Nieścior L., Cierniowa korona Jezusa w egzegezie Ojców Kościoła, w: Teologiczne podstawy kultu Chrystusa jako Króla, red. J. Grzywaczewski, Warszawa: Wydawnictwo Naukowe UKSW, 2018, s. 253-270.

Nieścior L., Profetyzm i apostolat Maryi z perspektywy pierwszych wieków, „Lumen Gentium. Zeszyty Misjologiczne”38/1 (2018) s. 30-45.

Paczkowski M., «Bóg stworzyt wszystko dla człowieka»? Zderzenie kosmocentryzmu z antropocentryzmem w późnoantycznej wizji świata stworzonego, VV 31 (2017) s. 283-319.

Perzyński A., Lineamenti di antropologia patristica, Padri del III secolo, „E-Patrologos” 3/1 (2017) s. 5-27. 
Stępień T., Porządek i miłość. Koncepcja Opatrzności Bożej w myśli starożytnej, Warszawa: Teologia Polityczna, 2019.

Terezis Ch. - Petridou J., The Theory on „Eide” According to Nicholas of Methone, VoxP 68 (2017) s. 551-568.

Uciecha A. Kult relikwii świętego Szczepana i nawracanie Żydów na podstawie „Epistula Severi”, SSHT 51/1 (2018) s. 64-75.

Uciecha A., Teologiczne podstawy monastycznej mistyki nestoriańskiej (syro-orientalnej) w Listach Jana z Dalijata, VoxP 70 (2018) s. 281-294.

Usacheva A., Grammar of Theology: Logical Argumentation from Origen to the Cappadocian Fathers, VoxP 68 (2017) s. 95-105.

Węsierski-Tesen K., Mahomet, w jakiego wierza muzułmanie w świetle Siry Ibn 'Ishâqa, SPelp 53 (2019) s. 517-532.

Widok N., Nadzieja w życiu pierwszych pokoleń chrześcijan. Interpretacja teologiczna, w: Nadzieje upadającego świata. Nadzieja w chrześcijańskiej epistolografi łacińskiej IV i V wieku (Ambroży, Augustyn, Hieronim, Paulin z Noli), red. M. Wysocki J. Pałucki - M. Pyzik-Turska, Lublin: Wydawnictwo KUL, 2019, s. 161-174.

Wołyniec W., Teologia starożytnego Synodu w Sirmium (351 r.) - między ortodoksja a herezja, SSHT 50/1 (2017) s. 29-44.

Wygralak P., Ojcowie Apostolscy o Bożej karze za grzechy, VV 36 (2019) s. 163-181.

Wysocki M., Chrystus Król i Jego królestwo - interpretacja pierwszych aleksandryjczyków, w: Teologiczne podstawy kultu Chrystusa jako Króla, red. J. Grzywaczewski, Warszawa: Wydawnictwo Naukowe UKSW, 2018, s. 29-48.

Zieliński T., Chrześcijaństwo starożytne, a filozofia rzymska, Sandomierz: Wydawnictwo Armoryka, 2017 (reprint wydania: Zamość: Zygmunt Pomarański i spółka, 1921).

Żurek A., Chrystus Król w patrystyce tacińskiej od III do V wieku, w: Teologiczne podstawy kultu Chrystusa jako Króla, red. J. Grzywaczewski, Warszawa: Wydawnictwo Naukowe UKSW, 2018, s. 49-62.

Żurek A., Duch Święty w świadomości pierwotnego Kościoła, w: Duch Święty, Źródło Wody Żywej [1], s. 357-369.

Żurek A., Duch Święty w Wyznaniu Wiary starożytnego Kościoła, w: Duch Święty, Źródło Wody Żywej [1], s. 371-383.

Żurek A., Pneumatologia patrystyczna, w: Duch Święty, Źródło Wody Żywej [1], s. 385-398.

Żurek A., Synody wczesnochrześcijańskie, w: Synody Diecezji Tarnowskiej, red. A. Żurek - J. Soprych, Dzieje Diecezji Tarnowskiej 7, Kraków: Wydawnictwo Naukowe UP Jana Pawła II, 2019, s. 31-47.

Żurek A., Symbol wiary jako przedmiot «disciplina arcani» w Kościele starożytnym, VoxP 67 (2017) s. 789-800. 


\section{Liturgia}

Dudek A., Le fonti patristiche e magisteriali della colletta per l'anniversario dell'Ordinazione sacerdotale, TST 37/1-2 (2018) s. 75-96.

Dudek A., Pszczoła, wosk i miód w liturgii rzymskiej, w: Pszczoły, miód, wosk pszczeli w symboliczno-metaforycznych obrazach. Od Biblii poprzez antyk do liturgii Kościoła, red. I. Wieżel - G.M. Baran, Kraków: Wydawnictwo „scriptum”, 2018, s. 197-228.

Ewangelistarz Płocki z XII wieku, Krytyczne wydanie tekstu łacińskiego z kodeksu Perykopy Ewangeliczne archiwum Diecezji Płockiej, opr. L. Misiarczyk - B. Degórski, Warszawa: Wydawnictwo Naukowe UKSW, 2017.

Grzywa A., Motyw eschatologiczny w rytach katechumenalnych i chrzcielnych na przykładzie homilii katechetycznych Teodora z Mopsuestii, RBL 70/3 (2017) s. 245-258.

Grzywa A., Ryty katechumenatu w okresie późnego Antyku. W poszukiwaniu analogii i modeli w świecie żydowskim i grecko-rzymskim, Kraków: Akademia Ignatianum, 2019.

Miazek J., Rękopiśmienne pontyfikały przedtrydenckie, WST 31/4 (2018) s. 132-145.

Misiarczyk L., Ewangeliarz księżnej Anastazji, Warszawa: Wydawnictwo Naukowe UKSW, 2017.

Potoczny M.R., Misterium chrzcielne w Asyryjskim Kościele Wschodu. Historia, liturgia $i$ teologia $w$ świetle pism ojców syro-orientalnych i komentatorów liturgii, Opole: Wydział Teologiczny Uniwersytetu Opolskiego, 2019.

Roszak P., Antropologiczne wątki rytu hiszpańsko-mozarabskiego z perspektywy euchologii «In initio anni», „Polonia Sacra” 23/1 (2019) s. 69-85.

Rucki M. - Abdalla M., Analiza porównawcza słownictwa nawiązującego do miłosierdzia Bożego $w$ syryjskiej anaforze św. Jakuba $w$ odniesieniu do kanonu modlitw żydowskich, PrzOr 3-4/267-268 (2018) s. 337-352.

Rucki M. - Abdalla M., Zapożyczenia greckie w syryjskiej anaforze Św. Jakuba Brata Pańskiego, PrzOr 1-2/261-262 (2017) s. 155-165.

Suski A. (opr.) - Miazek J. (wprow.), Libri Ordinarii. Przewodnik po rękopisach, Toruń: Wydawnictwo Adam Marszałek, 2019.

Turek W., "Lavacrum aquae in verbo». Liturgia chrzcielna $w$ Hipponie $w$ czasach św. Augustyna (próba rekonstrukcji), SSHT 50/1 (2017) s. 45-57.

Zurek A., Bierzmowanie jako sakrament inicjacji w Kościele starożytnym, w: Scripturae Lumen - Wtajemniczenie chrześcijańskie, red. G.M. Baran - J. Królikowski - P. Łabuda, Tarnów: Wydawnictwo Biblos, 2018, s. 367-381.

Żurek A., Eucharystia pierwszych wieków, w: Sakramenty Kościoła. Sakramenty wtajemniczenia chrześcijańskiego [1], s. 215-227.

Żurek A., Katechumen - chrześcijanin - wierny: przygotowanie do chrztu i chrzest w Kościele starożytnym, Teologia dla wszystkich 12, Tarnów: Wydawnictwo Biblos, 2017.

Żurek A., Liturgia słowa w świadectwie Ojców Kościoła, w: Liturgia uprzywilejowanym miejscem celebrowania Słowa Bożego, red. W. Pałęcki - A. Megger, Studia Liturgiczne 13, Lublin 2017, s. 11-22. 
Żurek A., Pokuta w starożytności chrześcijańskiej, w: Sakramenty Kościoła. Sakramenty uzdrowienia. Sakramenty w stużbie komunii [1], s. 67-79.

Żurek A., Sakrament chrztu w Kościele starożytnym, w: Sakramenty Kościoła. Sakramenty wtajemniczenia chrześcijańskiego [1], s. 73-88.

Żurek A., Sakrament bierzmowania w Kościele starożytnym, w: Sakramenty Kościoła. Sakramenty wtajemniczenia chrześcijańskiego [1], s. 143-156.

Żurek A., Sakrament malżeństwa w starożytnym Kościele, w: Sakramenty Kościoła. Sakramenty uzdrowienia. Sakramenty w stużbie komunii [1], s. 279-291.

Żurek A., Sakrament namaszczenia chorych w starożytności chrześcijańskiej, w: Sakramenty Kościoła. Sakramenty uzdrowienia. Sakramenty w stużbie komunii [1], s. 137-148.

Żurek A., Sakrament święceń (kapłańskich) w starożytności chrześcijańskiej, w: Sakramenty Kościoła. Sakramenty uzdrowienia. Sakramenty w stużbie komunii [1], s. 211-222.

\section{Hagiografia, monastycyzm, historia duchowości}

Biskup K., Krótka geneza monastycyzmu, TSS 14 (2017) s. 216-228.

Briskina-Müller A., Мотив преодоления себя-любия в «Апофтегматах Hatpym», „Е-Patrologos" 3/2 (2017) s. 74-89.

Chmielewski D., Walka duchowa u Ojców Pustyni, Zielonka: Wydawnictwo Sumus, 2019.

Ciemiała M., Stowo Boże a życie osobiste $i$ wspólnotowe wedlug pierwotnej katechezy cenobickiej, „Polonia Sacra” 21/3 (2017) s. 67-83.

Clément O., Źródła. Początki mistyki chrześcijańskiej, tom 3: Zbliżenie się do kontemplacji, tł. H. Paprocki, Warszawa: Wydawnictwo PROMIC, 2017.

Dąbek T.M., Praca w życiu mnichów, Z Tradycji Mniszej 65, Kraków: Wydawnictwo TYNIEC, 2017.

Filipowski M., Dieta w życiu ascetycznym Ojców pustyni, STV 1 (2017) s. 201-218.

Górecka-Kalita J., Żywot Świętego Jana Paulusa. Studium legendy, Kraków: Wydawnictwo UJ, 2018.

Kanior M. - Królikowski J., Monastycyzm. Specyfika teologiczna i zarys dziejów, Tarnów: Wydawnictwo Diecezji Tarnowskiej Biblos, 2018.

Kołosowski T., Troska o chorych $w$ klasztorach starożytnych $w$ świetle wybranych regut monastycznych, SaeCh 24 (2017) s. 5-16.

Kołosowski T., Życie gospodarczo-społeczne w klasztorach w Afryce Północnej w świetle wybranych pism św. Augustyna, VoxP 71 (2019) s. 327-349.

Kurek R., Ojcowie Pustyni, Kraków: Wydawnictwo m, 2018.

Lewandowicz J., Klasztory, mnisi, mniszki. Obraz życia monastycznego $w$ «Registrum epistolarum» Grzegorza Wielkiego na tle prawa kościelnego i kościelnego, Kraków: Wydawnictwo TYNIEC, 2018. 
Macios Z.A., Ruch monastyczny w Kapadocji na przykładzie działalności Bazylego Wielkiego, TSS 14 (2017) s. 229-246.

Mruk W., Homo sanctus. Wzorce świętych w Europie Łacińskiej w średniowieczu, Warszawa: Dom Wydawniczy PWN, 2018.

Nehring P., Dwie monastyczne koncepcje - o tym co łączy a zarazem dzieli Jana Kasjana iśw. Augustyna, VoxP 69 (2018) s. 527-545.

Nieścior L., Św. Ignacy Loyola (Ćw. 32-35) i mnisi starożytni o ascezie myśli, „E-Patrologos" 3/1 (2017) s. 75-89.

Nowak W., Św. Marcin z Tours: duchowość, kult, wzór ewangelizacji $w$ dziele integracji Europy, „Studia Elbląskie” 20 (2019) s. 245-256.

Pochwat J., Specyfika głównych ośrodków życia monastycznego w Galii w IV i V wieku, „Polonia Sacra” 21/3 (2017) s. 107-128.

Prostko-Prostński J., Czy św. Saba Got byt „,arianinem”?, w: W kręu antycznych politei [1], s. 331-339.

Przyszychowska M., Miłość własna (filautía) w rozumieniu ojców kapadockich, „E-Patrologos" 3/2 (2017) s. 49-55.

Sawicki R., Bliskość i różnice tradycji chrześcijańskiego monastycyzmu Wschodu i Zachodu, „Polonia Sacra” 22/2 (2018) s. 159-174.

Słomka J., Historia duchowości. Czas Ojców Kościoła, Katowice: Wydawnictwo Uniwersytetu Śląskiego, 2017.

Sydorak A., Вплив святоотиівської спадщини і святих православної Церкви на формування богословської думки Архимандрита Софронія Сахарова, VoхР 67 (2017) s. 573-597.

Szczur P., Antiochia Syryjska jako ośrodek ascezy $i$ monastycyzmu $w$ drugiej połowie IV w., VoxP 70 (2018) s. 45-69.

Szczur P., Posty w nauczaniu Ojców Kościoła, „Głos Katolicki” - „Voix Catholique” 59/7; 18.2.2018 (2018) s. 8-9.

Szram M., Wczesnochrześcijańskie ruchy paramonastyczne na podstawie «Diversarum hereseon liber» Filastriusza z Brescii oraz innych katalogów herezji, VoxP 70 (2018) s. 217-226.

Tomaszek M., Dziennik Opatów z Moyenmoutier. Święci i relikwie w narracji o historii klasztoru, Lublin: Wydawnictwo UMCS, 2017.

Turzyński P., Uczynki miłosierdzia u Ojców pustyni, AK 3 (2017) s. 447-461.

Wiąckiewicz D.J., Od Pachomiusza do Benedykta. Officium divinum w regułach monastycznych, STV 1 (2018) s. 163-198.

Wolińska T., Wizerunek pustyni i jej mieszkańców w świetle świadectw Świętych Ojców z Synaju, VoxP 70 (2018) s. 559-600.

Wygralak P., Znaczenie wyglądu zewnętrznego dziewic i mnichów w formacji duchowej w klasztorach Galii i Hiszpanii (VI-VII w.), VoxP 70 (2018) s. 227-241.

Wysocki M., Fílautia - zła miłość siebie w pismach aleksandryjczyków, „E-Patrologos” 3/2 (2017) s. 32-48. 
Wysocki M., Pewniejsza nadzieja? Zachęty do życia monastycznego $w$ epistolografii IV V wieku, VoxP 70 (2018) s. 193-204.

\section{Archeologia i historia sztuki}

Böhm M., Czy szwedzkie kamienie runiczne moga być świadectwem religijności Waregów stużacych $w$ gwardii cesarzy bizantyńskich z XI w.?, w: Święte wizerunki w przekazie Dobrej Nowiny, red. N. Widok, Opolska Biblioteka Teologiczna 161, Opole: Redakcja Wydawnictw Wydziału Teologicznego Uniwersytetu Opolskiego, 2017, s. 103-120.

Brzozowska Z., Jeden z herezjarchów? Przedstawienia ikonograficzne Mahometa w rękopisie Рнб, f.IV.151 w kontekście staroruskich narracji na jego temat, VoxP 70 (2018) s. 449-469.

Chisesi I., Co to za święty? Sztuka czytania obrazów. Słownik Ikonografii, Kielce: Wydawnictwo Jedność, 2018.

Ewangelistarz Płocki z XII wieku, Krytyczne wydanie tekstu łacińskiego z kodeksu Perykopy Ewangeliczne archiwum Diecezji Płockiej, opr. L. Misiarczyk - B. Degórski, Warszawa: Wydawnictwo Naukowe UKSW, 2017.

Guz A., Sprawiedliwość Boża jako jako motyw sztuki eschatologicznej średniowiecza, SPelp 52 (2018) s. 175-184.

Hiley D., Chorat Kościoła zachodniego. Podręcznik, tł. M. Kaziński, Kraków: Wydawnictwo Astraia, 2019.

Jakubek-Raczkowska M. - Czyżak M. (red.), Textus et pictura. Średniowieczny kodeks rękopiśmienny jako nośnik treści, znaczeń i wartości artystycznych, Toruń: Wydawnictwo Naukowe UMK, 2019.

Janocha M., Chrystus Pantokrator w ikonografii bizantyńskiej, w: Teologiczne podstawy kultu Chrystusa jako Króla, red. J. Grzywaczewski, Warszawa: Wydawnictwo Naukowe UKSW, 2018, s. 91-114.

Klejnowski-Różycki D., Nauka Addaja i legenda edeska o świętym Wizerunku, w: Święte wizerunki w przekazie Dobrej Nowiny, red. N. Widok, Opolska Biblioteka Teologiczna 161, Opole: Redakcja Wydawnictw Wydziału Teologicznego Uniwersytetu Opolskiego, 2017, s. 77-87.

Kochanek P., Schemat Krzyża i Grobu Chrystusa w kartografii średniowiecznej i wczesnonowożytnej, w: Święte wizerunki w przekazie Dobrej Nowiny, red. N. Widok, Opolska Biblioteka Teologiczna 161, Opole: Redakcja Wydawnictw Wydziału Teologicznego Uniwersytetu Opolskiego, 2017, s. 121-194.

Kochanek P., Vignetten von Konstantinopel in den Mittelalterlichen und Frühneuzeitlichen Karten. Die Entwicklung eines Graphischen Topos der Stadt, VoxP 70 (2018) s. 395-448.

Kochanek P., Winieta latarni morskiej w La Coruña na mapie Beatusa z Burgo de Osma w kontekście symboliki wczesnochrześcijańskiej, VoxP 71 (2019) s. 291-326. 
Martens-Czarnecka M., Archangel Michael and his peacock feathers in Nubian painting, w: Nubia Christiana, t. 2, Warszawa: Wydawnictwo Naukowe UKSW, 2020, s. 65-80.

Mazurczak U., Panorama Konstantynopola w «Liber chronicarum» Hartmanna Schedla (1493). Miasto idealne - «memoria» chrześcijaństwa, VoxP 70 (2018) s. 499-525.

Mazurczak U., Wizualizacja Chrystusa Króla w sztuce łacińskiej, w: Teologiczne podstawy kultu Chrystusa jako Króla, red. J. Grzywaczewski, Warszawa: Wydawnictwo Naukowe UKSW, 2018, s. 115-158.

Nowogórski P., Fundacja sanktuarium Kubbat As-Sachra wyrazem pobożności lub polityki kalifa Abd Al-Malika ibn Marwana, SaeCh 24 (2017) s. 39-46.

Nowogórski P., Starożytne miasta w basenie Morza Śródziemnego - w poszukiwaniu formy idealnej, SaeCh 26/2 (2019) s. 5-17.

Ożóg M. - Pietras H., Śladami pierwszych chrześcijan. Przewodnik kulturowy po wczesnochrześcijańskim Rzymie, Kraków: Wydawnictwo WAM, 2019.

Palusińska A., Hierarchiczność i partycypacja jako filozoficzne kategorie teorii ikony, Lublin: Wydawnictwo KUL, 2017.

Piórecka A., Kilka uwag o wptywie hezychazmu na przedstawienie chrztu Chrystusa na przykładzie sztuki z terenów Królestwa Serbii, VoxP 70 (2018) s. 485-497.

Smorąg Różycka M., Miejsce ekfrazy w bizantynistycznej historiografii artystycznej, VoxP 70 (2018) s. 471-484.

Starowieyski M., Wystawność, piękno i ubóstwo w pierwszych wiekach chrześcijaństwa, WST (2017) s. 367-379 (numer specjalny).

Stawoska-Jundziłł B., Wykształcona męczennica. Znaczenie wykształcenia w uzyskaniu zbawienia. Fresk z «cubiculum» Venerandy (katakumby Domitylli), w: W kregu antycznych politei [1], s. 365-377.

Sulikowska-Bełczowska A., "I gave milk to Him while He was feeding all the world» Representations of the "Galaktotrophousa» in Faras Cathedral, w: Nubia Christiana, t. 2, Warszawa: Wydawnictwo Naukowe UKSW, 2020, s. 43-64.

Varsimaszvili L., Średniowieczna architektura Gruzji, „Elpis” 21 (2019) s. 59-69.

Wiewiorowski J., Kolorystyka szczegółów geograficznych w «Notitia dignitatum pars orientis» wedtug rękopisów Oxoniensis Canonicianus Misc. 378 i Monacensis Latinus 10291, VoxP 70 (2018) s. 355-394.

Wujewski T., Życie starożytnych posąów, Poznań: Wydawnictwo Poznańskie, 2017.

Żelazny J.W., Znak krzyża we wspólnotach chrześcijan Pótwyspu Arabskiego w V-VI wieku, w: Święte wizerunki w przekazie Dobrej Nowiny, red. N. Widok, Opolska Biblioteka Teologiczna 161, Opole: Redakcja Wydawnictw Wydziału Teologicznego Uniwersytetu Opolskiego, 2017, s. 89-102.

Żak Ł., Duch Święty: gołębica, zajac czy kobieta? O wybranych przedstawieniach Ducha Świętego we wczesnochrześcijańskiej i średniowiecznej ikonografi oraz ich implikacjach pastoralnych, w: Duch, który żyje i ożywia. Teologiczno-pastoralne wymiary pneumatologii, red. T. Wielebski, Warszawa: Wydawnictwo Naukowe UKSW, 2019, s. 57-75. 


\section{Biblia}

Bardski K., Motyw drabiny Jakubowej (Rdz 28,10-22) w starożytnej symbolice zachodniego chrześcijaństwa, CT 88/4 (2018) s. 191-202.

Bardski K., Tradycyjna interpretacja alegoryczna Biblii z perspektywy współczesnej noematyki, w: Dla dobra Jego ciała, którym jest Kościót (Kol 1, 24) [1], s. 91-102.

Bejda W., Monarchia biblijna w «Starożytnościach żydowskich» Józefa Flawiusza w porównaniu z żydowska literatura drugiej świątyni i pismami rabinicznymi, Wrocław: Wydawnictwo TUM Wrocławskiej Księgarni Archidiecezjalnej, 2018.

Biblia Aramejska. Targum Neofiti 1, t. 2: Księga Wyjścia, tł. i opr. M.S. Wróbel, Lublin: Wydawnictwo Archidiecezji Lubelskiej Gaudium, 2017.

Biblia Aramejska. Targum Neofiti 1, t. 3: Księga Kapłańska, tł. i opr. A. Tronina, Lublin: Wydawnictwo Archidiecezji Lubelskiej Gaudium, 2019.

Biblia Aramejska. Wprowadzenie do Biblii Aramejskiej, wpr. M.S. Wróbel, Lublin: Wydawnictwo Archidiecezji Lubelskiej Gaudium, 2018.

Blajer P., Nadzieja zawieść nie może. Biblijne podstawy nadziei, w: Nadzieje upadajacego świata. Nadzieja w chrześcijańskiej epistolografii łacińskiej IV i V wieku (Ambroży, Augustyn, Hieronim, Paulin z Noli), red. M. Wysocki - J. Pałucki - M. Pyzik-Turska, Lublin: Wydawnictwo KUL, 2019, s. 145-160.

Charpin-Ploix M.-L., La réception du livre d'Amos par les Peres. Proposition méthodologique, VoxP 67 (2017) s. 71-83.

Czarnuch M., Ewangelia Marka w komentarzu Teofylakta, Tarnów: Wydawnictwo BIBLOS, 2018.

Górka B., «En arche en ho logos» (J 1,1a) - próba przełamania interpretacyjnych dogmatów, w: Święte wizerunki w przekazie Dobrej Nowiny, red. N. Widok, Opolska Biblioteka Teologiczna 161, Opole: Redakcja Wydawnictw Wydziału Teologicznego Uniwersytetu Opolskiego, 2017, s. 197-207.

Knut T.S., Biblijne opowiadanie o wieży Babel (Rdz 11.1-9) w interpretacji żydowskich pism z okresu drugiej światyni, Pelplin: Wydawnictwo Bernardinum, 2018.

Królikowski J., Od jednej Ewangelii Chrystusa do czterech Ewangelii Kościoła, VoxP 71 (2019) s. 351-372.

Mateja L., Dwie wersje «Modlitwy Pańskiej» odczytane w kluczu inicjacyjnym, VoxP 67 (2017) s. 389-401.

Mateja L., Inicjacyjny charakter XI rozdziału Listu do Hebrajczyków, VoxP 69 (2018) s. 467-479.

Mickiewicz F., Starożytne dyskusje nad autentycznością i kanonicznością Listu św. Judy, w: Dla dobra Jego ciała, którym jest Kościół (Kol 1, 24) [1], s. 257-273.

Mikołajczak M., Biblijne implikacje o ustanowieniu Eucharystii, w: Ojcowie Kościoła o Eucharystii, red. P. Wygralak, Teologia Patrystyczna 14, Poznań: Wydział Teologiczny 2017, s. 23-42.

Morta K., Biblijny szafan - problem identyfikacyjno-egzegetyczny, VV 32 (2017) s. 351-396. 
Nocoń A., «Uporzadkujcie we mnie mitość» (Pnp 2, 4 wg LXX) w egzegezie wybranych autorów Wschodu i Zachodu, VoxP 67 (2017) s. 477-497.

Paczkowski M.C., Esegesi patristica di Gv 4,21-24 e il vero culto a Gerusalemme (II parte), BPTh 12/1 (2019) s. 43-69.

Paczkowski M.C., Isaiah 56:7 in the Patristic Interpretation, BPTh 12/4 (2019) s. 469-495.

Paczkowski M.C., Zbawienie i jego geograficzny wymiar $w$ patrystycznej interpretacji Ps 74(73), 12, BPTh 11/1 (2018) s. 35-56.

Pierzchała K., Chrystologia starotestamentowa w ujęciu Corpus Paulinum i Listu do Hebrajczyków, Lublin: Towarzystwo Naukowe KUL, 2019.

Podeszwa P., «Zwycięzcy dam mannę ukryta» (Ap 2,17). Eucharystia pokarmem upamiętniającym Pana w świetle Apokalipsy Janowej, w: Ojcowie Kościoła o Eucharystii, red. P. Wygralak, Teologia Patrystyczna 14, Poznań: Wydział Teologiczny, 2017, s. 7-22.

Szczur P., Miłosierdzie Pana na wieki wyśpiewywać będę (Ps 88,2), „Głos Katolicki” „Voix Catholique” 59/13; 1-8.4.2018 (2018) s. 15.

Szram M., Jezus Chrystus - Figury, w: Nowy stownik teologii biblijnej, red. H. Witczyk, Lublin: Towarzystwo Naukowe KUL - Kielce: Wydawnictwo Jedność, 2017, s. 340-343.

Szram M., «Wszystko ma swój czas». Patrystyczna egzegeza Księgi Eklezjastesa 3,1-8, VV 35 (2019) s. 345-372.

Terka M., Z dziejów egzegezy perykopy o Marii i Marcie (Lk 10, 38-42), czyli jak św. Tomasz z Akwinu rozumiat św. Augustyna. Przyczynki do teologii kontemplacji i życia czynnego, „Veritati et Caritati” 12 (2019) s. 597-642.

Uciecha A., Egzegeza biblijna w komentarzach syryjskich Afrahata, Efrema, Iszodada z Merw i Teodora Bar Koni. Zarys problematyki, VoxP 67 (2017) s. 673-688.

Wojciechowski M., Dwie wersje Dziejów Apostolskich. Teksty standardowy i zachodni, Kraków: Wydawnictwo Petrus, 2018.

Wysocki M., Biblia i nadzieja na jej dobre tlumaczenie, VoxP 69 (2018) s. 721-733.

Żurek A., Moralny i eklezjalny sens polecenia amputacji członków ciała (Mt 5,29-30 i Mt 18,8-9), w: Dla dobra Jego Ciała, którym jest Kościót (Kol 1,24) [1], s. 519-534.

\subsection{Apokryfy}

Apokryficzne księgi Barucha, [Syryjska Apokalipsa Barucha; Objawienie dane Baruchowi; Reszta stów Barucha], tł. i opr. A. Tronina, AST 5, Kraków-Mogilany: The Enigma Press, 2018.

Apokryfy Nowego Testamentu. Tom 1, część 1 i 2: Ewangelie apokryficzne, red. M. Starowieyski, wyd. 2, Kraków: Wydawnictwo WAM, 2017.

Apokryfy Nowego Testamentu. Tom 2, część 1 i 2: Apostotowie, red. M. Starowieyski, wyd. 2, Kraków: Wydawnictwo WAM, 2017. 
Apokryfy Nowego Testamentu. Tom 3: Listy i apokalipsy chrześcijańskie. Apokryfy syryjskie, red. M. Starowieyski, wyd. 2, Kraków: Wydawnictwo WAM, 2017.

Baran M.G., Czwarta Księga Machabejska ttem «Mowy» XV św. Grzegorza z Nazjanzu, VoxP 67 (2017) s. 41-70.

Baran G.M., Siedmiu braci Machabejskich z «Czwartej Księgi Machabejskiej» jako typ Chrystusa. Próba zastosowania egzegezy typologicznej do tekstu «Czwartej Ksiegi Machabejskiej», VoxP 71 (2019) s. 43-67.

Czwarta Księga Ezdrasza Zwana też Druga bądź Trzecia Księga Ezdrasza, Proroctwem Ezdrasza lub Apokalipsa Ezdrasza, z łacińskiego przetłumaczył Ks. Jakub Wujek, S.J., Sandomierz: Wydawnictwo Armoryka, 2019 (reprint).

Jezus. Biografia nieautoryzowana, wybór i układ P.M. Szewczyk, wstęp M. Starowieyski, Kraków: Wydawnictwo WAM, 2018 (wybór wszystkich tekstów zebranych w tym tomie na podstawie wydania: Apokryfy Nowego Testamentu, t. 1-3, red. M. Starowieyski, Kraków 2017).

Klejnowski-Różycki D., Nauka Addaja i legenda edeska o świętym Wizerunku, w: Święte wizerunki w przekazie Dobrej Nowiny, red. N. Widok, Opolska Biblioteka Teologiczna 161, Opole: Redakcja Wydawnictw Wydziału Teologicznego Uniwersytetu Opolskiego, 2017, s. 77-87.

Księga Jubileuszy czyli Mała Genesis, tłum. i kom. A. Tronina, AST 4, Kraków-Mogilany: The Enigma Press, 2018.

Miduch M., Orzel i lew jako dwie przeciwstawne sobie sity czasów ostatecznych w «Czwartej Księdze Ezdrasza», VV 32 (2017) s. 215-230.

Miduch M., Rytualna kapiel, gest pokuty czy zapowiedź chrztu? Obmycie $w$,, wiecznie płynacych rzekach” w «Czwartej księdze sybilliańskiej», w: Scripturae Lumen - Wtajemniczenie chrześcijańskie, red. G.M. Baran - J. Królikowski - P. Łabuda, Tarnów: Wydawnictwo BIBLOS, 2018, s. 95-104.

Miduch M., «Wypali całkowicie wszystko i pozostanie palacy się pyt» (4Syb 177). Eschatologiczna kara w przekazie IV Księgi Sybilliańskiej, VV 36 (2019) s. 67-80.

Ody Salomona 9, 14, 28, 32 i 34, przekład z j. syryjskiego z wprowadzeniem P. Jutkiewicz, WST 32/2 (2019) s. 138-154.

Parchem M., Obraz Boga w apokryficznych Psalmach Salomona, w: Dla dobra Jego ciata, którym jest Kościót (Kol 1, 24) [1], s. 337-353.

Parchem M., Wydarzenia czasów ostatecznych w hymnicznych proroctwach eschatologicznych Księgi Daniela (Dn 12,1-3) i Testamentu Mojżesza (TestMojż 10,1-10), SPelp 53 (2019) s. 389-410.

Reguła Zrzeszenia i inne teksty prawne wspólnoty z Qumran. Adnotowany przekład z hebrajskiego $1 Q S, 1 Q S a, 1 Q S b, C D, 1 Q M$, tł. i opr. A. Tronina, Kraków-Mogilany: The Enigma Press, 2017.

Sala B.G., Bestie i potwory biblijne, istoty fantastyczne dziel kanonicznych i apokryficznych, Olszanica: Wydawnictwo Bosz, 2019. 
Starowieyski M. - Kozłowska J. - Kozłowski J.M., Opowiadania muzułmańskie zawierajace stowa Jezusa, WST 31/3 (2018) s. 130-161.

Wyrzykowski M., Kapłaństwo w świetle greckiego «Testamentu Lewiego» [14-16], WST 31/3 (2018) s. 30-44.

Ze skarbca biblijnych apokryfów (Pokuta Adama, Psalmy Salomona, Żywoty Proroków, Drabina Jakubowa, Protoewangelia Jakuba), tł. i kom. A. Tronina, AST 6, Kraków-Mogilany: The Enigma Press, 2019.

Zwój Hymnów Dziękczynnych z Qumran (1QHodajot ${ }^{a}$ ), rekonstrukcja - przekład - komentarz: P. Dec, Kraków-Mogilany: The Enigma Press, 2017.

\subsection{Gnostycyzm}

Apokaliptyka w pismach gnostyckich, wstęp, W. Myszor - P. Piwowarczyk, tłum. i kom.

W. Myszor - A. Sowińska, red. A. Sowińska, Katowice: Wydział Teologiczny UŚ, 2017.

Biblioteka z Nag Hammadi. Kodeksy I i II, tł. i kom. W. Myszor, SACh SN 7, wyd. 2,

Katowice: Centrum Badań nad Gnostycyzmem i Doktrynami Pokrewnymi - Katedra

Teologii Patrystycznej i Historii Kościoła UŚ, 2017.

Biblioteka z Nag Hammadi. Kodeks IX, tł., wst. i kom. W. Myszor, red. W. Kamczyk, SACh SN 21, Katowice: Centrum Badań nad Gnostycyzmem i Doktrynami Pokrewnymi - Katedra Teologii Patrystycznej i Historii Kościoła UŚ, 2019.

Ewangelia Judasza, tł., wst. i kom. W. Myszor, SACh SN 3, wyd. 2, Katowice: Centrum Badań nad Gnostycyzmem i Doktrynami Pokrewnymi - Katedra Teologii Patrystycznej i Historii Kościoła UŚ, 2019.

Inicjacja manichejska wedtug rozdziału 9 koptyjskich «Kephalaia Nauczyciela» (Keph. 37, 28-42, 23), tł. i kom. M. Dobkowski, w: Magia Ksiag - Księgi Magii [1], s. 19-40.

List Piotra do Filipa z «Kodeksu Tchacos», tekst i wprowadzający komentarz filologiczny A. Sowińska, SSHT 52/2 (2019) s. 38-48.

Obcy (Allogenes) Czwarty utwór z «Kodeksu Tchacos», wstęp, przekład i komentarz P. Piwowarczyk, SSHT 52/2 (2019) s. 23-37.

Artemi E., The Heretic Gnostic and the Real «Gnostic» in Christ according to the Teaching of Irenaeus of Lyon, VoxP 69 (2018) s. 39-52.

Koprowski P., Wątki gnostyckie w myśli genezyjskiej Juliusza Słowackiego, SPelp 53 (2019) s. 261-274.

Mrugalski D., Metamorfozy platońskiej «metafory słońca» (Respublica 509b) w hetero$i$ ortodoksyjnej teologii (I-III w.): Gnostycyzm, Klemens z Aleksandrii i Orygenes, VoxP 68 (2017) s. 21-58.

Szczur P., Walentyniańska interpretacja biblijnego opisu stworzenia człowieka (Rdz 1, 26-27) w przekazie Klemensa Aleksandryjskiego, VoxP 68 (2017) s. 59-71.

Tatar M., Rozum wobec wiary - współczesna pokusa gnostycyzmu, WST 32/1 (2019) s. 6-24. 
Zieliński T., Hermes Trismegistos, Sandomierz: Wydawnictwo Armoryka, 2017 (przedruk wydania z 1920 roku).

Zmorzanka A.Z., Formuła $\sigma \tilde{\omega} \mu \alpha-\sigma \tilde{\eta} \mu \alpha w$ «Księdze Tomasza Atlety» i jej aspekty ontyczno-etyczne, VoxP 67 (2017) s. 767-777.

\section{Patrystyka i średniowiecze (lacińskie i bizantyńskie)}

\subsection{Przekłady}

Alan z Lille, Księga przystów, tł., wstęp i kom. B. Spieralska-Kasprzyk, „Bibliotheca Litterarum Medii Aevi” Artes-Opera (Opera nr 3), Warszawa: Wydawnictwo IBL PAN, 2018.

Anna Komnene, Aleksjada, tł. H. Pietruszczak, Zgorzelec: Wydawnictwo Henryk Pietruszczak, 2018.

Bonawentura, Itinerarium mentis in Deum VII, 6, tł. M. Jóźwiak, w: M. Kiwka, Mistyczne odkrywanie Boga w «Itinerarium mentis in Deum» św. Bonawentury, „Studia Philosophiae Christianae" 53/2 (2017) s. 116.

Cezary z Heisterbach, Dialog o cudach, tł. H. Pietruszczak, Zgorzelec: Wydawnictwo Henryk Pietruszczak, 2019.

Ewangeliarz księżnej Anastazji, tł. i opr. L. Misiarczyk, Warszawa: Wydawnictwo Naukowe UKSW, 2017.

Gerwazy z Tilbury, O cudach świata, tł. Henryk Pietruszczak, Zgorzelec: Wydawnictwo Henryk Pietruszczak, 2017.

Grzegorz Palamas, Triady w obronie świętych hezychastów, tom. 1-2, tł. I. Zogas-Osadnik, b.m.w.: Wydawnictwo Theos-Logos, 2019.

Humbert z Romans, O głoszeniu i stuchaniu słowa Bożego, Poznań: W drodze, 2017.

Hugon ze św. Wiktora, De Verbo Dei, wpr. i tł. P. Chojnacka - M.J. Janecki, BPTh 12/3 (2019) s. 305-330.

Hugon ze św. Wiktora, Didaskalion, czyli co i jak czytać, tł. P. Pludra-Żuk, wstęp J. Soszyński, Warszawa: Wydawnictwo IBL PAN, 2017.

Jordan z Saksonii, Najdroższej Dianie..., Poznań: W drodze, 2017.

Kronika Książąt Polskich (Chronica principum Poloniae), tł. i opr. J. Wojtczak-Szyszkowski, Opole: Wydawnictwo i Drukarnia Św. Krzyża, 2019.

Księga monstrów (Liber monstrorum), tł. i opr. J. Sokolski, Bibliotheca Curiosa 36, Wrocław: Oficyna Wydawnicza ATUT - Wrocławskie Wydawnictwo Oświatowe, 2019.

Latopis nowogrodzki pierwszy starszej redakcji, tł. i opr. Z.A. Brzozowska - I.N. Petrov J. Morawicki, Series Ceranea 5, Łódź: Wydawnictwo Uniwersytetu Łódzkiego, 2019. 
Leon z Vercelli, Metrum Leonis, czyli wilcza zbrodnia, wstęp, thum. i kom. J. Stadler, Kraków: Wydawnictwo Homini, 2019 (edycja dwujęzyczna).

Piotr Damiani, Pisma monastyczne, tł. E. Buszewicz, red. K. Skwierczyński, ŹrMon 83, Kraków: Wydawnictwo TYNIEC, 2018.

Piotr Damiani, Żywot błogosławionego Romualda, pustelnika i opata, tł. E. Buszewicz, Kraków: Wydawnictwo TYNIEC, 2019.

Piotr Lombard, Cztery Księgi Sentencji, tł. J. Wojtkowski, t. 1-2, Olsztyn: b.w., 2015.

Rajmund Lull, Księga stanu rycerskiego, wstęp i tł. R. Sasor, Kraków: Instytut Studiów Franciszkańskich, 2019.

Saxo Grammaticus, Gesta Danorum. Dzieje Duńczyków, tł. H. Pietruszczak, Zgorzelec:

Wydawnictwo Henryk Pietruszczak, 2018.

Tomasz z Akwinu, Dysputa o prawdzie. Dysputy problemowe o prawdzie. Kwestia 1, tł. A. Białek, tekst przekładu przejrzeli M.A. Krąpiec - A. Maryniarczyk, Lublin: Polskie Towarzystwo Tomasza z Akwinu, 2018 (wydanie polsko-łacińskie).

Tomasz z Akwinu, Komentarz do «O duszy» Arystotelesa, tł. i wstęp M. Beściak, Ad Fontes 28, Kęty: Wydawnictwo Marek Derewiecki, 2018.

Tomasz z Akwinu, Wyktad Listu do Efezjan. Super epistolam b. Pauli ad Ephesios lectura, red. P. Roszak - E. Alarcón, tł. J. Marszałek - P. Roszak - A. Kubanowski, Scholastica Thorunensia 3, Toruń: Wydawnictwo Naukowa UMK, 2017.

Tomasz z Celano, Żywot naszego Ojca błogosławionego Franciszka, opr. i ed. J. Dalarun, tł. A. Horowski, Kraków: Instytut Studiów Franciszkańskich, 2017.

Tomasz Sutton, De esse et essentia, t. 1, tł. P. Kordula, wstęp D. Lipski, Warszawa: Biblioteka Rocznika Tomistycznego, 2018.

Wilhelm z Saint-Thierry, Złoty list (do braci z Mont-Dieu), tł. W. Mohort-Kopaczyński, red. i wstępy P. Chojnacki - M.T. Gronowski - A.M. Piazzoni, ŹrMon 66, Kraków: Wydawnictwo TYNIEC, 2013 (dodruk 2017).

\subsection{Opracowania}

Alexandrowicz P., Znaczenie dekretału Intelleximus (X 5.32.1) w procesie recepcji prawa rzymskiego w XIII-wiecznej kanonistyce, Kraków: Wydawnictwo scriptum, 2018.

Aubé P., Św. Bernard z Clairvaux, tł. Ł. Maślanka, Biografie Sławnych Ludzi, Warszawa: Państwowy Instytut Wydawniczy, 2019.

Baran W., Grzech pierworodny w tradycji Piotra Lombarda, Kraków: Wydawnictwo scriptum, 2019.

Böhm M., Normanowie $w$ dziełach Geralda z Walii a świat bizantyński, VoxP 69 (2018) s. 53-64.

Brzozowska Z.A., Obraz Bizancjum w tekstach hagiograficznych poświęconych księżnej Oldze (XI-XVI wiek), w: Rzymianie i barbarzyńcy [1], s. 115-132. 
Brzozowska Z.A. - Leszka M.J., Maria Lekapene, Empress of the Bulgarians. Neither a Saint nor a Malefactress, Byzantina Lodzensia 36, Łódź: Wydawnictwo Uniwersytetu Łódzkiego, 2018.

Brzozowska Z.A. - Leszka M.J. - Marinow K., Piotr I Święty car butgarski (ok. 912 969); Maria Lekapena caryca bułgarska (ok. 912 - ?963), Kraków: Wydawnictwo AVALON, 2018.

Cobb P.M., Krucjaty. Arabska perspektywa, tł. M. Józefowicz, Kraków: Wydawnictwo Astra, 2018.

Czarnuch M., Ewangelia Marka w komentarzu Teofylakta, Tarnów: Wydawnictwo BIBLOS, 2018.

Foryt A., «Gestes des Chiprois» jako cypryjska kompilacja historyczna z XIV w. Kronika Ziemi Świętej, Zabrze-Tarnowskie Góry: Wydawnictwo inforteditions, 2018.

Garnczarska M., Inspiracje artystyczne pomiędzy kultura bizantyńska a muzułmańska w okresie od X do XIII wieku, w: Rzymianie i barbarzyńcy [1], s. 27-45.

Grzeszczak J., Moralna wymowa gestu namaszczenia stóp i głowy Jezusa w «Quaestio de Maria Magdalena et Maria sorore Lazari et Marthae» Joachima z Fiore, VoxP 69 (2018) s. 175-193.

Holdon J, Wojny Bizancjum. Strategia, taktyka, kampanie, tł. N. Radomski, Poznań: Wydawnictwo Rebis, 2018.

Hupalo M., Божественні енергії та богословський метод у вченні св. Григорія Палами, VoxP 69 (2018) s. 219-240.

Kucharski J. - Marciniak P. - Warcaba K., Nie tylko dialogi. Recepcja twórczości Lukiana w Bizancjum, Katowice: Wydawnictwo Uniwersytetu Śląskiego, 2019.

Latoszek P., Papiestwo a regnum piastowskie w latach ok. 965-973, SaeCh 24 (2017) s. 54-67.

Leszka M.B. - Leszka M.J., Bazylisa. Świat bizantyjskich cesarzowych $I V-X V$ w., Łódź: Wydawnictwo Uniwersytetu Łódzkiego, 2017.

Leszka M.J., Car bułgarski Piotr (927-969) w bizantyńskiej historiografii X-XII wieku, VoxP 70 (2018) s. 339-354.

Leszka M.J., Watek arabski w stosunkach bułgarsko-bizantyńskich w VII-X wieku, w: Rzymianie i barbarzyńcy [1], s. 15-25.

Malinowski R., Rola eunuchów na dworze cesarzy bizantyńskich. Przypadek Narzesa, VoxP 67 (2017) s. 373-387.

Marinow K., Patrząc na przemoc. Postawa, odczucia i bezsilność człowieka wobec okropności wojny w świetle retoryki okresu średniobizantyńskiego, VoxP 69 (2018) s. 449-465.

Marinow K. - Leszka M.J., The Bulgarian State in 927-969. The Epoch of Tsar Peter I, Byzantina Lodzensia 34, Łódź: Wydawnictwo Uniwersytetu Łódzkiego, 2018.

Marszalska J.M., "Via in caelestium Cisterciense». Księgi, wieczność i czas w ujęciu charyzmatu zakonu cystersów, w: Niebo. Tradycje, przekazy, inspiracje [1], s. 85-94.

Marszalska J.M., Skryptoria klasztorne i średniowieczne ustawodawstwo cysterskie o ksiązce, SaeCh 24 (2017) s. 68-74. 
Milewski I., Wczesnobizantyński system podatkowy $w$ świetle wybranych relacji hagiograficznych, „Studia Gdańskie” 43 (2019) s. 87-95.

Rosenwein, B.H., Wspólnoty emocjonalne we wczesnym średniowieczu, Warszawa: Wydawnictwo IBL PAN, 2018.

Rutkowski R., Norweska kronika Mnicha Teodoryka. Pótnocna tradycja historyczna wprowadzona w nurt dziejów powszechnych (koniec XII wieku), Toruń: Wydawnictwo Naukowe UMK, 2019.

Skowronek M., Średniowieczne opowieści biblijne. Paleja historyczna w tradycji bizantyńsko-słowiańskiej, Series Ceranea 4, Łódź: Wydawnictwo Uniwersytetu Łódzkiego, 2017.

Strumiłowski J.P., Średniowieczna teologia cysterska, czyli «theoria» w stużbie «praxis», SSHT 50/1 (2017) s. 58-69.

Strzelczyk J., Gerbert z Aurillac - Sylwester II. Papież i uczony z przełomu tysiacleci, Wrocław: Wydawnictwo chromcon, 2019.

Strzelczyk J., Otton I Wielki, Poznań: Wydawnictwo Poznańskie, 2018.

Strzelczyk J., Raj ziemski i niebieski w wyobraźni ludzi średniowiecza, w: Niebo. Tradycje, przekazy, inspiracje [1], s. 71-84.

Strzelczyk J., Święci władcy Słowian południowych, SaeCh 26/2 (2019) s. 28-49.

Switkiewicz-Blandzi A., Pseudo-Dionizy a Grzegorz Palamas. Bizantyjska synteza wschodniej patrystyki, Warszawa: Wydawnictwo Naukowe Sub Lupa, 2018.

Terka M., Z dziejów egzegezy perykopy o Marii i Marcie (Łk 10, 38-42), czyli jak św. Tomasz z Akwinu rozumiat św. Augustyna. Przyczynki do teologii kontemplacji i życia czynnego, „Veritati et Caritati” 12 (2019) s. 597-642.

Warcaba K., Bizantyński epos dla średnio zaawansowanych. «Katomyomachia» Teodora Prodromosa jako tekst trzeciego stopnia, Katowice: Wydawnictwo Uniwersytetu Śląskiego, 2017.

Walkowski G.K., Historia Niemiec w latach 843-1137 cz. 1: Lata 843-1024. Otton II król Niemiec i cesarz, Bydgoszcz: Wydawnictwo Bogart, 2019.

Wickham Ch., Rzym średniowieczny. Stabilizacja i kryzys miasta w latach 900-1150, tł. A. Bugaj, Kęty: Wydawnictwo Marek Derewiecki, 2018.

Wierzbiński Sz., Szlachetni, odważni, dzicy? Obraz Waregów i Franków w oczach Bizantyńczyków w X-XI w., VoxP 69 (2018) s. 647-679.

Wierzbiński Sz., U boku bazyleusa. Frankowie $i$ Waregowie w cesarstwie bizantyńskim w XI w. Byzantina Lodziensia 37, Łódź: Wydawnictwo Uniwersytetu Łódzkiego, 2019.

Wolski J.M., Kultura monastyczna w późnośredniowiecznej Bułgarii, Byzantina Lodziensia 30, Łódź: Wydawnictwo Uniwersytetu Łódzkiego, 2018.

Zhukovskyy V., Святий- «єретик» Григорій Палама про внутрішнє буття Пресвятої Tpiüui, VoxP 68 (2017) s. 569-592. 


\title{
11. Autorzy
}

\begin{abstract}
Afrahat
-, O święcie Paschy (Demonstratio XII: De paschate, PSyr 1, 505-540), tt. i kom. A. Uciecha, SSHT 50/2 (2017) s. 5-18.

-, O pokarmach czystych i nieczystych (Demonstratio XV: De dictinctione ciborum, $\mathrm{PSyr}$ 1, 728-757), tt. i kom. A. Uciecha, SSHT 51/2 (2018) s. 345-360.

-, O narodach, które zastapity naród (Demonstratio XVI: De Gentibus quae Loco Populi Suffectae Sunt, PSyr 1, 760-784), tł. i kom. A. Uciecha, VoxP 71 (2019) s. 575-591.

-, Przeciw Żydom o dziewictwie i świętości (Demonstratio XVIII: Adversus Iudaeos de virginitate et sanctitate, PSyr 1, 817-844), tt. i kom. A. Uciecha, VoxP 68 (2017) s. 593-604. -, O śmierci i czasach ostatecznych (Demonstratio XXII: De morte et novissimis temporibus, PSyr 1, 992-1049), tt. i kom. A. Uciecha, VoxP 69 (2018) s. 797-815.
\end{abstract}

\section{Akatyst}

Grzywaczewski J., Okoliczności kompozycji hymnu Akatyst ku czci Najświętszej Maryi Pan$n y$, VoxP 69 (2018) s. 195-218.

\begin{abstract}
Alkuin
-, Poezje (wybór), tł., wstęp i przyp. T. Gacia, VoxP 72 (2019) s. 239-251.
\end{abstract}

\section{Amalariusz z Metzu}

Dzieła, t. 2: Porzadek antyfonarza. Inne pisma o świętych obrzędach. Reguly życia duchownych i mniszek, red. T. Gacia, Lublin: Towarzystwo Naukowe KUL, 2017.

\section{Ambroży}

Kamczyk W., Grzeszna kobieta (Łk 7,36-50) jako obraz Kościoła w nauczaniu św. Ambrożego, VoxP 67 (2017) s. 177-195.

Śrutwa J., Św. Ambroży duszpasterz polityków, w: Veni Domine [1], s. 595-604. 
Wysocki M., Can Children be Mature in the Faith? A Study of the Works of St. Ambrose, w: Il bambino nelle fonti Christiane. XLV Incontro di Studiosi dell'Antichità Cristiana (Roma, 11-13 05 2017), red. M. Ghilardi, Studia Ephemerides Augustinianum 154, Roma - Lugano: Institutum Patristicum Augustinianum, 2019, s. 295-303.

Wysocki M., Godne przyjmowanie Eucharystii w listach św. Ambrożego i św. Augustyna, w: Ojcowie Kościoła o Eucharystii, red. P. Wygralak, Teologia Patrystyczna 14, Poznań: Wydział Teologiczny, 2017, s. 147-168.

Wysocki M., Nadzieja na jedność? Herezje i heretycy $w$ «Listach» św. Ambrożego, VoxP 68 (2017) s. 327-340.

Wysocki M., How to Measure the Time of God and the Time of Men? Study of the Letters of Ambrose and Augustine, w: Tempo di Dio, tempo dell'uomo. XLVI Incontro di Studiosi dell'Antichità Cristiana (Roma, 10-12 V 2018), red. M. Ghilardi, Studia Ephemerides Augustinianum 155, Roma - Lugano: Institutum Patristicum Augustinianum, 2019, s. 441-449.

Zimny W., Biblijne figury Eucharystii w pismach św. Ambrożego, w: Ojcowie Kościoła o Eucharystii, red. P. Wygralak, Teologia Patrystyczna 14, Poznań: Wydział Teologiczny, 2017, s. 117-146.

\section{Anastazy Synajski}

-, Przewodnik II, CCG 8, s. 23-75, tł. M. Przyszychowska, w: M. Przyszychowska, Czy "O definicjach» (Liber de definitionibus) Pseudo-Atanazego z Aleksandrii to II rozdziat «Przewodnika» (Viae dux) Anastazegoz Synaju?, „E-Patrologos” 4/1 (2019) s. 55-90, kol. 2.

Jóźwiak M., Et ait: «Faciamus hominem ad imaginem et similitudinem nostram» (Rdz 1, 26). Próba egzegezy bizantyńskiej na przykładzie „, Komentarza do Księgi Rodzaju” Anastazego z Synaju, VoxP 70 (2018) s. 545-557.

\section{Andrzej z Krety}

Leśniewski K., "The Great Canon» of St. Andrew of Crete. Scriptural, Liturgical and Hesychastic Invitation for an Encounter With God, VoxP 69 (2018) s. 429-447.

Prelipcean A., Does the "Great Canon» of Andrew of Crete Speak about the Heresies and Their Combating? Brief Remarks, VoxP 68 (2017) s. 523-533. 


\section{Anonim}

-, «Komentarz do Ksiegi Hioba» (Commentarii in Job), czyli epitoma «Komentarza do historii Hioba» Filipa Prezbitera, wstęp, tł. i przyp. M. Jóźwiak, Wrocław: Tum, Wydawnictwo Wrocławskiej Księgarni Archidiecezjalnej, 2018.

Jóźwiak M., Elihu jako mędrzec w historii egzegezy Księgi Hioba na przykładzie anonimowego «Commentarii in Job», VoxP 71 (2019) s. 255-270.

Jóźwiak M., Świat zwierząt w anonimowym «Commentarii in Job», VV 32 (2017) s. 421-444.

\section{Antoni Wielki (Pseudo-)}

-, Naszego w gronie świętych Ojca Antoniego Wielkiego pouczenia o zachowaniu ludzi i właściwym sposobie postępowania, tł. C. Dobak, w: Pseudo-Antoni Wielki, Izajasz Anachoreta, Wybór tekstów z I tomu «Filokalii», red. i kom. Sz. Hiżycki, Kraków: Wydawnictwo TYNIEC, 2017, s. 42-105.

\section{Apoftegmaty Ojców}

Jak żyć według Ojców Pustyni?, opr. Sz. Hiżycki - J. Zelek, Kraków: Wydawnictwo TYNIEC, 2017.

Nocoń A., Obraz Boga w «Apoftegmatach Ojców Pustyni», VoxP 70 (2018) s. 93-105.

\section{Apolinary z Laodycei}

Orton R., Struggling with Christology: Apolinarius of Laodicea and St Gregory of Nyssa, VoxP 68 (2017) s. 243-251.

\section{Arnobiusz Starszy}

-, Adversus nationes, Księgi 1-2, tł. i kom. K. Homa, Kraków: Akademia Ignatianum, 2019.

-, Życie i smierć Attisa. Adversus nationes V 6-7, tł. A. Kucz, „Scripta classica” 14 (2017) s. 57-62.

Homa K., Arnobiusz - afrykański orator, Kraków: Wydawnictwo WAM, 2017. 


\section{Asteriusz z Amazji}

-, Mowa czternasta: Na początek świętego postu, tł. M. Przyszychowska, w: Post jako praktyka duchowa. Ojcowie Kościoła o poście [1], s. 75-90.

\section{Atanazy}

-, Chrystus i Jego Kościót. Siedem listów [Epistula ad Marcellinum; Epistula ad Amun; Epistula ad Dracontium; Epistula encyclica; Epistula ad Epictetum; Epistula ad Adelphium; Epistula ad Maximum], tł. i wstęp P. Szewczyk, Kraków: Wydawnictwo WAM, 2017.

-, Historia arian spisana dla mnichów, tł. i wstęp E. Dusik-Krupa, ŹMT 80, Kraków: Wydawnictwo WAM, 2018.

-, Żywot św. Antoniego Wielkiego, tł. E. Dąbrowska, Kraków: Wydawnictwo TYNIEC, 2017.

Kaczmarek P., W poszukiwaniu specyfiki myśli maryjnej św. Atanazego Wielkiego, „Teologia w Polsce" 13/2 (2019) s. 223-236.

Koniecko B., Nie żartujcie sobie z Bóstwa! Kontrowersje teologiczne w IV w. dotyczace Ducha Świętego na podstawie «Listów do Serapiona» św. Atanazego oraz dzieła «O Duchu Świętym» św. Bazylego Wielkiego, Kraków: Wydawnictwo TYNIEC, 2019.

Perzyński A.P., Atanasio, Didimo, Gregorio di Nissa. Lineamenti di antropologia patristica, ,E-Patrologos” 3/4 (2017) s. 57-79.

Zhukovskyy V., Творещь і творіння, Бог і людина, сутність й енергія в богословській думиі Атанасія Олександрійського, VoхР 67 (2017) s. 743-765.

\section{Atanazy (Pseudo-)}

-, O definicjach, PG 28, 533-553, tł. M. Przyszychowska, w: M. Przyszychowska, Czy "O definicjach» (Liber de definitionibus) Pseudo-Atanazego z Aleksandrii to II rozdział «Przewodnika» (Viae dux) Anastazego z Synaju?, „E-Patrologos” 4/1 (2019) s. 55-89, kol. 1.

\section{Augustyn z Hippony}

-, Kazania na Boże Narodzenie i Objawienie Pańskie, tł. i opr. M. Stróżyński, Kęty: Wydawnictwo Marek Derewiecki, 2019.

-, Kazanie 363 - O pieśni z Księgi Wyjścia 15,1-21, tł. i opr. W. Kamczyk, VoxP 72 (2019) s. 253-269. 
-, List 87 [Do Emeryta] (Epistula 87, CPL 262), tł., wstęp, i kom. R. Toczko, VoxP 67 (2017) s. 801-812.

-, Listy 128-129 [Do Marcellina], tł., wstęp i przyp. T. Kołosowski, VoxP 72 (2019) s. 271-294.

-, O pożytku płynacym z postu, tł. J. Januszewski, w: Post jako praktyka duchowa. Ojcowie Kościoła o poście [1], s. 141-155.

-, O świętym dziewictwie, tł. P. Nehring, Z Tradycji Mniszej 72, Kraków: Wydawnictwo TYNIEC, 2019.

-, Przeciw listowi Parmeniana, wprowadzenia, tł. i opr. T. Kołosowski, PSP 70, Warszawa: Wydawnictwo Naukowe UKSW, 2019.

-, Psalm abecadtowy przeciwko donatystom, wprowadzenie, tł. i kom. S. Adamiak, BPTh 10/4 (2017) s. 445-461.

-, Wyznania, tł. Z. Kubiak, wyd. 6, Kraków: Wydawnictwo ZNAK, 2018.

-, Wyznania, ks. 1, tł. S. Stabryła, „Nowy Filomata” 22/1 (2018) s. 61-76.

Adamiak S., Unfriendly and polemical elements in Augustine's correspondence with other clerics", ZACh 22/1 (2018) s. 110-124.

Andoková M. - Horka R., The Chronology of Augustine's "Tractatus in Iohannis evangelium»1-16 and «Enarrationes in psalmos»119-133 Revisited, VoxP 72 (2019) s. $149-170$.

Czyżewski B., "Chleba naszego powszedniego daj nam dzisiaj» (Mt 6,11) w interpretacji św. Augustyna, w: Ojcowie Kościoła o Eucharystii, red. P. Wygralak, Teologia Patrystyczna 14, Poznań: Wydział Teologiczny, 2017, s. 169-186.

Czyżewski B., Nauka św. Augustyna o gniewie Boga w „Enarrationes in psalmos”, VV 33 (2018) s. 315-341.

Degórski B., La Chiesa e la vita monastica in Sant'Agostino, w: Misja: istota i chwata Kościoła katolickiego, red. A.A. Napiórkowski, Cracoviensis cogitatio Ecclesiae 10, Kraków: Uniwersytet Papieski Jana Pawła II, 2019, s. 177-192.

Dybała J., Miłość własna według św. Augustyna, „E-Patrologos” 3/4 (2017) s. 5-22.

Dytrych G., Dziewictwo i matżeństwo w piśmie św. Augustyna «O dziewictwie», „E-Patrologos" 4/1 (2019) s. 32-49.

Eckmann A., Państwo w nauczaniu Świętego Augustyna, w: W kręgu antycznych politei [1], s. 95-105.

Grzywa A., Eklezjologia miłości wedtug św. Augustyna, „E-Patrologos” 3/4 (2017) s. 39-49.

Grzywaczewski J., Św. Augustyna interpretacja przypowieści o Dobrym Samarytaninie (Łk 10, 20-37), „E-Patrologos” 3/3 (2017) s. 17-36.

Hood J.Y.B., «Inimici nostri»: Jews as Heretics and Heretics as Judaizers in Jerome and Augustine, VoxP 68 (2017) s. 341-353.

Jaśkiewicz S., Duch Święty jako Miłość w «De Trinitate» św. Augustyna, TST 37/1-2 (2018) s. 31-46.

Kamczyk W., Duszpasterska interpretacja opisu stworzenia świata (Rdz 1:1-31) w serii homilii paschalnych Augustyna, „Oecumenica Silesiana” 1 (2018) s. 33-46. 
Kamczyk W., Męczeństwo i kult braci Machabejskich w nauczaniu św. Augustyna, VoxP 69 (2018) s. 241-256.

Kamczyk W., Miłość i pożądliwość cielesna w doktrynie św. Augustyna, „E-Patrologos” 3/3 (2017) s. 47-61.

Kamczyk W., Pijaństwo jako problem moralny i duszpasterski u św. Augustyna, BPTh 10/1 (2017) s. 77-99.

Kamczyk W., Miejsce i rola wspólnoty monastycznej w Kościele wedtug św. Augustyna, VoxP 70 (2018) s. 151-169.

Kasprzak D., Miłość a lęk według św. Augustyna, biskupa Hippony, „E-Patrologos” 3/3 (2017) s. 37-46.

Kijewska A., "Na początku stworzył Bóg niebo i ziemię...» Św. Augustyn i Jan Szkot Eriugena. Pomiędzy alegoria a historia, w: Niebo. Tradycje, przekazy, inspiracje [1], s. 47-70.

Kołosowski T., Życie gospodarczo-społeczne w klasztorach w Afryce Północnej w świetle wybranych pism św. Augustyna, VoxP 71 (2019) s. 327-349.

Królikowski J., Kościót widzialny i niewidzialny w ujęciu św. Augustyna, w: Kościót. Narodziny i rozwój eklezjologii chrześcijańskiej [1], s. 183 -200.

Lichner M., Saint Augustine's 80th Homily on the Gospel of John. Text analysis as a contribution to the debate on understanding baptism, „Studia Nauk Teologicznych PAN" 13 (2018) s. 197-214.

Łupiński J., Konkubinat $w$ życiu i poglądach Augustyna z Hippony, „E-Patrologos” 3/4 (2017) s. 23-38.

Marciniak B.J., Medical metaphors in Augustine's letters, VoxP 71 (2019) s. 373-388.

Marek Z. - Walulik A., Ponadczasowość myśli dydaktycznej świętego Augustyna, PChr 39/1 (2017) s. 29-47.

Nehring P., Dwie monastyczne koncepcje - o tym co łaczy a zarazem dzieli Jana Kasjana iśw. Augustyna, VoxP 69 (2018) s. 527-545.

Nieścior L., Ideał miłości uporządkowanej (caritas ordinata) u św. Augustyna, „E-Patrologos" 3/3 (2017) s. 5-16.

Pasterczyk P., U źródeł pojęcia ludzkiej woli-studium koncepcji woli Augustyna z Hippony w'świetle platońskiej teorii duszy, Lublin: Wydawnictwo KUL, 2018.

Setlak W., Antropologia i historiozofia Aureliusza Augustyna. Kilka uwag o istocie myśli filozoficznej doktora Kościoła i jej kulturotwórczej mocy, „Studia Redemptorystowskie" 15 (2017) s. 69-80.

Stróżyński M., Kontemplacja Boga u św. Augustyna w perspektywie ewolucji jego filozofi, „Filozofia Chrześcijańska” 14 (2017) s. 87-106.

Sylwestrzak A., Filozofia pokoju św. Augustyna, „Studia Elbląskie” 19 (2018) s. 261-276.

Święs K., Aktualność myśli św. Augustyna dla współczesnej nauki społecznej Kościoła, w: Dla dobra Jego ciała, którym jest Kościót (Kol 1, 24) [1], s. 465-477.

Terka M., Czy większość ma rację w Kościele? O niektórych aspektach «multitudo» w nauczaniu św. Augustyna, „Veritati et Caritati” 10 (2018) s. 449-494. 
Terka M., Man's Animality in the Light of St. Augustine's Philosophical Works, VoxP 67 (2017) s. 631-652.

Turek W., Jakimi językami postugiwali się starożytni chrześcijanie Afryki Północnej? Analiza odnośnych tekstów Tertuliana, św. Cypriana i św. Augustyna, VoxP 72 (2019) s. 27-48.

Turek W., Praca fizyczna w życiu monastycznym. Argumentacja św. Augustyna $w$ «De opere monachorum», VoxP 70 (2018) s. 170-191.

Turzyński P., Istotne cele i zasady edukacyjne w myśli świętego Augustyna, „Rocznik Naukowy Duszpasterstwa Nauczycieli” 2 (2018) s. 13-29.

Wendlik K., Serce to umyst. Mistyka spotkania Boga i człowieka w ujęciu Orygenesa oraz św. Augustyna - inspiracje IV Ewangelii, Kraków: Wydawnictwo Wejdźmy na szczyt, 2017.

Wojcieszak M., Społeczność Kościoła Afryki rzymskiej w relacji św. Augustyna, SPelp 53 (2019) s. 557-579.

Wojcieszak W., Zwyczaje pogrzebowe Afryki rzymskiej w pismach św. Augustyna, SPelp 51 (2017) s. 445-456.

Wysocki M., "Czyż i Afryka nie jest petna ciat męczenników?» (Augustyn, «Ep.»78, 3). Męczeństwo jako rys duchowości Afryki Pótnocnej, VoxP 72 (2019) s. 203-217.

Wysocki M., Godne przyjmowanie Eucharystii w listach św. Ambrożego i św. Augustyna, w: Ojcowie Kościoła o Eucharystii, red. P. Wygralak, Teologia Patrystyczna 14, Poznań: Wydział Teologiczny, 2017, s. 147-168.

Wysocki M., How to Measure the Time of God and the Time of Men? Study of the Letters of Ambrose and Augustine, w: Tempo di Dio, tempo dell'uomo. XLVI Incontro di Studiosi dell'Antichità Cristiana (Roma, 10-12 V 2018), red. M. Ghilardi, Studia Ephemerides Augustinianum 155, Roma - Lugano: Institutum Patristicum Augustinianum, 2019, s. 441-449.

Zarzycki S.T., Prawda o Bogu Stwórcy, stworzeniu i jego odnowie, wedtug «Wyznań» św. Augustyna, VoxP 71 (2019) s. 543-571.

Zgraja B., Symbolika księżyca w «Enarrationes in psalmos» św. Augustyna, VoxP 69 (2018) s. 735-753.

Żurek A., Dilige et quod vis fac - sens stynnej formuly Augustyna, „E-Patrologos” 3/3 (2017) s. 62-69.

Żurek A., Obrzęd bierzmowania w nauczaniu św. Augustyna, VoxP 69 (2018) s. 771-782.

\section{Auzoniusz}

-, Dzieła, t. 1, tł., wstęp i przyp. J. Stadler, Biblioteka Antyczna 56, Wrocław: Instytut Studiów Klasycznych, Śródziemnomorskich i Orientalnych Uniwersytetu Wrocławskiego, 2017. 


\section{Barsanufiusz i Jan}

Szykuła R., Ojcostwo duchowe w listach Barsanufiusza i Jana z Gazy, Kraków: Wydawnictwo TYNIEC, 2019.

\section{Bazyli Wielki}

-, Mowy o poście 1-2, tł. M. Przyszychowska, w: Post jako praktyka duchowa. Ojcowie Kościoła o poście [1], s. 55-73.

-, Pogańscy mistrzowie chrześcijan. Bazyli Wielki. Do młodzieży o wykorzystaniu literatury pogańskiej. Poprzedzony wymiana listów z Libaniuszem, tł. i opr. P. Błażewicz, Warszawa: PIW, 2017.

Czyżewski B., Korespondencja św. Bazylego Wielkiego w sprawie nadużyć duchownych, w: Dei enim sumus adiutores. Opuscula Adamo Przybecki Septuagenario Dedicata, red. M. Polak, Poznań: Wydział Teologiczny UAM, 2019, s. 27-38.

Kochańczyk-Bonińska K., Basil the Great contra Eunomius and His Thesis - The state of Research, SPelp 51 (2017) s. 189-201.

Kochańczyk-Bonińska K., Basil the Great's References to Eunomius, VoxP 68 (2017) s. 119-128.

Kochańczyk Bonińska K., Defining Substance in Basil the Great's Dispute with Eunomius about the Incomprehensibility of God, „E-Patrologos” 4/1 (2019) s. 93-103.

Koniecko B., Nie żartujcie sobie z Bóstwa! Kontrowersje teologiczne w IVw. dotyczace Ducha Świętego na podstawie «Listów do Serapiona» św. Atanazego oraz dzieła «O Duchu Świętym» Św. Bazylego Wielkiego, Kraków: Wydawnictwo TYNIEC, 2019.

Macios Z.A., Ruch monastyczny w Kapadocji na przykładzie działalności Bazylego Wielkiego, TSS 14 (2017) s. 229-246.

Paczkowski M., Anatomia gniewu wedtug Bazylego Wielkiego, VV 34 (2018) s. 291-313.

Paczkowski M., Biblia i filozofia w konfrontacji Bazylego Wielkiego z apolinaryzmem, VoxP 68 (2017) s. 217-241.

Panagopoulos G., The Theory of «epinoia» in St. Basil of Caesarea and Eunomius of Cyzicus: Philosophical and Theological Background, VoxP 68 (2017) s. 129-138.

Zhukovskyy V., Апофатична тріадологія та катафатична синергія у богословській думиі Василія Великого, VохР 70 (2018) s. 71-92.

\section{Beda Czcigodny}

-, Komentarz do Apokalipsy świętego Jana, wstęp, tł. i opr. D. Sztuk, PSP 73, Warszawa: Wydawnictwo Naukowe UKSW, 2019. 
Budzanowska-Weglenda D., Beda Czcigodny o wczesnym chorale gregoriańskim w Anglii ( Historia ecclesiastica» IV 24), VoxP 71 (2019) s. 69-85.

Ryczek W., "Ut figura sit». Beda Czcigodny o tropach Pisma, VoxP 69 (2018) s. 573-594. Puchalska-Dąbrowska B.M., Beda Czcigodny i bohaterowie «Historii kościelnej narodu angielskiego» w polskim piśmiennictwie religijnym XVI-XVIII wieku, Warszawa: Wydawnictwo Naukowe Sub Lupa, 2017.

Sztuk D., Osobliwości obrazu Kościoła i ewangelizacji w komentarzu do Apokalipsy św. Bedy Czcigodnego, „Seminare” 39/4 (2018) s. 11-20.

\section{Benedykt z Nursji}

Waal de E., Szukanie Boga. Droga św. Benedykta, Kraków: Wydawnictwo TYNIEC, wyd. 2, Kraków 2020.

\section{Centony}

Centony Homeryckie, tł. i kom. D. Piasecki, wprow. K. Narecki, Kraków: Wydawnictwo scriptum, 2017.

Drzyżdżyk Sz., Chrystologia w perspektywie Mitu Trojańskiego, Horyzonty Dogmatu 3, Kraków: Wydawnictwo scriptum, 2017.

Migdał M. - Piątek M.K., Chrystologia «Christus patiens», Kraków: Wydawnictwo scriptum, 2017.

Piątek M.K., Chrystologia biblijna - pogańskie litery. Na przykładzie chrześcijańskiego centonu «De Verbi Incarnatione», RBL 72/2 (2019) s. 149-158.

\section{Cezary z Arles}

-, Pisma monastyczne, tł. E. Czreny - M. Borkowska - J. Piłat, wstęp J. Piłat, ŹrMon 2, wyd. 2, Kraków: Wydawnictwo TYNIEC, 2018.

Pochwat J., Sprawiedliwość Boga wobec Szatana na podstawie «Jedenastego kazania do ludu»św. Cezarego z Arles, „Polonia Sacra” 21/4(49) (2017) s. 167-185.

Pochwat J., Wybrane aspekty z przepowiadania św. Cezarego z Arles. Czy św. Cezary $z$ Arles będzie nowym doktorem Kościoła?, „Polonia Sacra” 23/4 (2019) s. 139-158.

Wygralak P., Pastoralne przesłanie komentarza św. Cezarego z Arles do Apokalipsy św. Jana, VoxP 67 (2017) s. 715-726. 


\section{Chromacjusz z Akwilei}

Sajovic M., «Sermo eorum sicut cancer serpit». Chromatius of Aquileia Against Heresies, VoxP 68 (2017) s. 443-455.

\section{Cyprian z Kartaginy}

-, Dzietka pobożne (O śmiertelności; $O$ miłosiernych uczynkach i jałmużnie; O cierpliwości; $O$ modlitwie Pańskiej), Warszawa: Wydawnictwo Theophilus, 2018 (przedruk wydania „Świętego Cypriana Ojca Kościoła i męczennika Dziełka pobożne na polski język przetłumaczone”, Kraków: Nakładem OO. Jezuitów w Krakowie. Drukiem A. Koziańskiego 1900).

Mejzner M., Vantaggio o perdita? Le facce della misericordia nel «De opere et eleemosynis» di Cipriano, „Gregorianum” 98/1 (2017) s. 51-60.

Misiarczyk L. Polemika z Żydami i judaizmem w «Ad Quirinium» (liber primus) Cypriana z Kartaginy, VoxP 72 (2019) s. 79-95.

Turek W., Jakimi językami postugiwali się starożytni chrześcijanie Afryki Północnej? Analiza odnośnych tekstów Tertuliana, św. Cypriana i św. Augustyna, VoxP 72 (2019) s. $27-48$.

Wygralak P., Cypriana z Kartaginy refleksje o realnej obecności Chrystusa w Eucharystii, w: Ojcowie Kościoła o Eucharystii, red. P. Wygralak, Teologia Patrystyczna 14, Poznań: Wydział Teologiczny, 2017, s. 85-96.

Żelazny J., Cyprian u Tymoteusza. Odwołania do decyzji synodalnych Cypriana z Kartaginy $w$ polemice $w$ Kościele Orientalnym $w$ VIII wieku, VoxP 72 (2019) s. 121-130.

\section{Cyryl Aleksandryjski}

Charyło A., Chrystologia św. Cyryla Aleksandryjskiego, Warszawa: Warszawska Metropolia Prawosławna, 2018.

\section{Cyryl Jerozolimski}

Widok N., List do Rzymian w «Katechezach» Cyryla Jerozolimskiego. Sposoby wykorzystania i interpretacji, VoxP 69 (2018) s. 623-645.

Widok N., Polemika antyheretycka $w$ «Katechezach» Cyryla Jerozolimskiego, VoxP 68 (2017) s. 423-442. 


\section{Dhuoda z Septymanii}

Chudzikowska-Wołoszyn M., Idea «compassio fraterna» w parenetycznej instrukcji Dhuody z Septymanii († ok. 843), VoxP 71 (2019) s. 87-113.

Chudzikowska-Wołoszyn M., Recepcja źródeł ascetycznych $i$ monastycznych $w$ «Liber manualis» Dhuody z Septymanii (ok. 803-843), VoxP 69 (2018) s. 105-123.

\section{Doroteusz z Gazy}

-, Opowieść o świętym Ojcu Doroteuszu, tł. A. Wojnowski, Hajnówka: Wydawnictwo Bratczyk, 2018 (jest to wznowienie pozycji wydanej w 2001: Abba Doroteusz, Żywot i pouczenia).

Turzyński P., Opieka nad chorymi jako droga do świętości wedtug św. Doroteusza z Gazy, VoxP 70 (2018) s. 107-118.

\section{Drakoncjusz}

Cichoń N., Drakoncjusz w więzieniu: siła poezji przeciwko sile władzy, VoxP 69 (2018) s. $125-141$.

\section{Dydym Ślepy}

-, Komentarz do Księgi Psalmów (papirus z Tura), część 1: Ps 20-30 (LXX), wstęp, opr. i tł. R.M. Pancerz, Kalwaria Zebrzydowska: Wydawnictwo Bernardynów Calvarianum, 2018.

Czyżewski B., Księga proroka Zachariasza w egzegezie Dydyma Aleksandryjskiego i św. Hieronima, VoxP 67 (2017) s. 85-100.

Grzywaczewski J., L'opération propre de l'Esprit Saint d'apres Didyme l'Aveugle, VoxP 67 (2017) s. 133-148.

Perzyński A.P., Atanasio, Didimo, Gregorio di Nissa. Lineamenti di antropologia patristi$c a$, ,E-Patrologos” 3/4 (2017) s. 57-79.

\section{Efrem Syryjczyk}

Kurek J., Saint Ephrem the Syrian: Sacred Time and Historical Time Seen from a Crossroads of Cultures, SSHT 50/1 (2017) s. 19-28. 
Uciecha A., Między symbolem a prawda. Eucharystia w «Hymnach o Przaśnikach» św. Efrema Syryjczyka, w: Ojcowie Kościoła o Eucharystii, red. P. Wygralak, Teologia Patrystyczna 14, Poznań: Wydział Teologiczny, 2017, s. 97-116.

\section{Egeria}

Czyżewski B., Itinerarium Egerii na temat światła, VoxP 71 (2019) s. 115-130.

\section{Ekumeniusz}

Wojciechowski M., Metoda egzegetyczna w komentarzu do Apokalipsy Ekumeniusza, BPTh 11/1 (2018) s. 87-99 = Exegetical Method in Oecumenius' Commentary on the Revelation, „Annali di storia dell'esegesi” 36/1 (2019) s. 201-211.

\section{Ennodiusz z Pawii}

Skibiński T., Barbarzyńcy $w$ «Vita Epifani» Ennodiusza z Pawii, VoxP 72 (2019) s. 219-235.

\section{Epifaniusz z Salaminy}

Pancerz R.M., Obrona integralnego człowieczeństwa Chrystusa przeciw apolinaryzmowi $w$ dziełach Epifaniusza z Salaminy, VoxP 68 (2017) s. 253-269.

Widok N., Udział Epifaniusza z Salaminy w walce z kultem obrazów, w: Święte wizerunki w przekazie Dobrej Nowiny, red. N. Widok, Opolska Biblioteka Teologiczna 161, Opole: Redakcja Wydawnictw Wydziału Teologicznego Uniwersytetu Opolskiego, 2017, s. 9-36.

\section{Eriugena Jan Szkot}

Grzegorzyca A., Eriugeny koncepcja stworzenia wszystkiego z niczego w człowieku, „Studia Philosophiae Christianae" 55/1 (2019) s. 47-69.

Grzegorzyca A., Platońskie idee i Eriugeny przyczyny prymordialne w kontekście ich przyczynowości i poznawalności, „Studia Philosophiae Christianae” 53/4 (2017) s. 31-47.

Kijewska A., "Na początku stworzył Bóg niebo i ziemię...» Św. Augustyn i Jan Szkot Eriugena. Pomiędzy alegoria a historia, w: Niebo. Tradycje, przekazy, inspiracje [1], s. 47-70. 
Kijewska A., Eriugeny koncepcja powrotu: dzieło natury czy łaski?, „Filozofia Chrześcijańska” 15 (2018) s. 31-58.

\section{Eunomiusz z Kyziku}

Kochańczyk-Bonińska K., Basil the Great contra Eunomius and His Thesis - The State of Research, SPelp 51 (2017) s. 189-201.

Kochańczyk-Bonińska K., Basil the Great's References to Eunomius, VoxP 68 (2017) s. 119-128.

Kochańczyk Bonińska K., Defining Substance in Basil the Great's Dispute with Eunomius about the Incomprehensibility of God, „E-Patrologos” 4/1 (2019) s. 93-103.

Panagopoulos G., The Theory of «epinoia» in St. Basil of Caesarea and Eunomius of Cyzicus: Philosophical and Theological Background, VoxP 68 (2017) s. 129-138.

Przyszychowska M., The Commonly Accepted Statement (to homologoumenon) as a Starting Point for a Theological Discussion - Eunomius and Gregory of Nyssa, VoxP 68 (2017) s. 139-148.

Stępień T., "There are Two Roads Marked Out to Us for the Discovery of What we Seek...» Eunomius' Arguments on the Generation of the Son Based on the Concepts of Substance and Activity, VoxP 68 (2017) s. 107-118.

\section{Euzebiusz z Aleksandrii (Pseudo-)}

-, Mowa pierwsza: O poście, tł. M. Przyszychowska, w: Post jako praktyka duchowa. Ojcowie Kościoła o poście [1], s. 103-109.

\section{Euzebiusz z Cezarei}

-, Żywot Konstantyna, tł. H. Pietruszczak, Zgorzelec: Wydawnictwo Henryk Pietruszczak, 2019.

\section{Ewagriusz z Pontu}

-, Biblia jak pocisk. Jak walczyć z myślami? Metoda antyretyczna wedtug Ewagriusza z Pontu, Kraków: Wydawnictwo TYNIEC, 2018.

Biernat J., Znaczenie modlitwy i kontemplacji w walce duchowej u Ewagriusza Pontyjskiego w ujęciu Anselma Grüna, ,Studia Redemptorystowskie” 17 (2019) s. 93-112. 
Laskowska A.M., Rodzaje myśli wedtug Ewagriusza z Pontu, „E-Patrologos” 3/1 (2017) s. 63-74.

Misiarczyk L., «Non errores mentis sed logismoi faciunt haereses». The Passions as a Source of Heresy according to Evagrius Ponticus, VoxP 68 (2017) s. 271-281.

Misiarczyk L., Origen as a Source of Evagrian eight passionate thoughts, „Seminare” 39/4 (2018) s. 191-205.

Nieścior L., W sporze ze złymi myślami. Lektura Ewagriusza z Pontu dzisiaj, Kraków: Wydawnictwo m, 2018.

Rivas R.P., Dreams in Evagrius Ponticus'Life and Teaching, VoxP 67 (2017) s. 523-542.

Smoła J., Ogrody cnót i uzdrowieńcze zdroje duszy w ćwiczeniach duchowych Ewagriusza z Pontu, Przysietnica: Materiały Wspólnot Katolickich „Ludzie Zboisk”, 2019.

Smoła J., Ojciec Duchowy, człowiek napetniony Duchem Świętym w ikonach Ewagriusza z Pontu, Przysietnica: Materiały Wspólnot Katolickich „Ludzie Zboisk”, 2018.

\section{Ewagriusz Scholastyk}

Ginter K., Wizerunek władców bizantyńskich w «Historii kościelnej» Ewagriusza Scholastyka, Byzantina Lodziensia 35, Łódź: Wydawnictwo Uniwersytetu Łódzkiego, 2018.

\section{Filastriusz z Brescii}

Szram M., Egzegeza literalna Starego Testamentu jako źródło herezji - stanowisko Filastriusza z Brescii, VoxP 67 (2017) s. 619-629.

Szram M., Herezje skrypturystyczne w «Diversarum hereseon liber» Filastriusza z Brescii, w: Dla dobra Jego ciała, którym jest Kościót (Kol 1, 24) [1], s. 435-450.

Szram M., Pojęcie herezji w rozumieniu Filastriusza z Brescii, w: W stużbie Bogu bogatemu w miłosierdzie w archidiecezji i metropolii warmińskiej. Księga jubileuszowa księdza arcybiskupa dra Wojciecha Ziemby Metropolity Warmińskiego i Wielkiego Kanclerza Wydziatu Teologii Uniwersytetu Warmińsko-Mazurskiego w Olsztynie z okazji 50-lecia święceń prezbiteriatu i 35-lecia sakry biskupiej, red. K. Parzych-Blakiewicz - J. Pawlik - P. Rabczyński - M. Żmudziński, Olsztyn: Wydział Teologii Uniwersytetu Warmińsko-Mazurskiego, 2017, s. 385-394.

Szram M., Radykalna asceza jako herezja $w$ «Diversarum hereseon liber» Filastriusza z Brescii i innych wczesnochrześcijańskich katalogach ruchów heretyckich, w: Veni Domine. Księga pamiątkowa w 50. rocznicę święceń biskupich Księdza Biskupa prof. dr. hab. Juliana Wojtkowskiego, red. A. Kopiczko, Pelplin: Wydawnictwo Bernardinum, 2019, s. 647-657.

Szram M., Rygoryzm i laksyzm moralny we wczesnochrześcijańskich ruchach heretyckich na podstawie «Diversarum hereseon liber» Filastriusza z Brescii, RT 64/4 (2017) s. 35-51. 
Szram M., "Varii errores qui ab origine mundi emerserunt». The Semantic Scope of the Term «Heresy» in Philastrius' of Brescia «Diversarum hereseon liber», VoxP 68 (2017) s. 315-325.

Szram M., Wczesnochrześcijańskie ruchy paramonastyczne na podstawie «Diversarum hereseon liber» Filastriusza z Brescii oraz innych katalogów herezji, VoxP 70 (2018) s. 217-226.

\section{Filon z Aleksandrii}

Kuderski K., Pojęcie serca jako źródła cnót w refleksji Filona z Aleksandrii, „Elpis” 20 (2018) s. 65-69.

Misiarczyk L., Terapeuci-żydowscy prekursorzy monastycyzmu chrześcijańskiego w „De vita contemplativa" Filona z Aleksandrii, VoxP 70 (2018) s. 9-23.

Mrugalski D., Bóg niezdolny do gniewu. Obrona «apathei» Boga w teologii aleksandryjskiej: Filon, Klemens i Orygenes, VV 33 (2018) s. 279-314.

Nieścior L., Ślady egzegezy Filona Aleksandryjskiego w „De monastica exercitatione” Nila z Ancyry, VoxP 70 (2018) s. 25-44.

\section{Fotyn z Sirmium}

Bodrožić I. - Kraft Soić V., Heretical Doctrine of Photinus of Sirmium in Hilary of Poitiers' «De Trinitate», VoxP 68 (2017) s. 283-314.

\section{Fredegariusz (Pseudo-)}

-, Fredegarii Scholastici Chronicum. Kronika Uczonego Fredegara, tł. G.K. Walkowski, Warszawa: nakładem autora, 2017 (także tekst łaciński).

\section{Gaudencjusz z Brescii}

Degórski B., Concetto lineare del tempo nel dialogo salvifico di Dio con l'umanità secondo $i$ «Tractatus» di san Gaudenzio di Brescia, w: Tempo di Dio, tempo dell'uomo. XLVI Incontro di Studiosi dell'Antichità Cristiana (Roma, 10-12 V 2018), red. M. Ghilardi, Studia Ephemerides Augustinianum 155, Roma - Lugano: Institutum Patristicum Augustinianum, 2019, s. 357-369. 


\section{Grzegorz z Nazjanzu}

Artemi E., The Divine Personhood of the Holy Spirit in the Teaching of Gregory Nazianzen, VoxP 68 (2017) s. 179-192.

Baran M.G., Czwarta Księga Machabejska ttem «Mowy» XV św. Grzegorza z Nazjanzu, VoxP 67 (2017) s. 41-70.

Dybała J., Kobiety w listach Grzegorza z Nazjanzu, BPTh 10/3 (2017) s. 391-421.

Widok N., Zalecenia i zachęty do życia doskonałego w korespondencji Grzegorza z Nazjanzu, VoxP 67 (2017) s. 689-713.

\section{Grzegorz z Nyssy}

-, Na słowa: «Wtedy także sam syn podda się temu, który poddał mu wszystko» (1Kor 15, 28) (In illud: "Tunc et ipse Filius», CPG 3151), tł., wstęp i kom. M. Przyszychowska, VoxP 69 (2018) s. 837-862.

Manikowski M., «Ekstasis» $i$ «epektasis» jako dwa elementy opisujace doświadczenie mistyczne wedtug Grzegorza z Nyssy, „Filozofia Chrześcijańska” 14 (2017) s. 71-86.

Mrugalski D., Eschatologiczna niepoznawalność istoty Boga: Próba przekroczenia metafizyki Arystotelesa w ujęciu Grzegorza z Nyssy i Tomasza z Akwinu, „Przegląd Tomistyczny" 25 (2019) s. 369-403.

Orton R., Struggling with Christology: Apolinarius of Laodicea and St Gregory of Nyssa, VoxP 68 (2017) s. 243-251.

Perzyński A.P., Atanasio, Didimo, Gregorio di Nissa. Lineamenti di antropologia patristi$c a$, ,E-Patrologos” 3/4 (2017) s. 57-79.

Przyszychowska M., The Commonly Accepted Statement (to homologoumenon) as a Starting Point for a Theological Discussion - Eunomius and Gregory of Nyssa, VoxP 68 (2017) s. 139-148.

Steenbuch J.A., From Abstraction to Unsaying: How the Eunomian Controversy Changed Gregory of Nyssa's Aphairetic Ethics to an Apophatic Ethics, VoxP 68 (2017) s. 149-164.

Szram M., Koncepcja kary a hipoteza apokatastazy w eschatologii Grzegorza z Nyssy, VV 36 (2019) s. 183-215.

Vigorelli I., «Schesis» and «homoousios» in Gregory of Nyssa's "Contra Eunomium»: Metaphysical Contest and Gains to Trinitarian Thought, VoxP 68 (2017) s. 165-177.

Wyrąbkiewicz A., Mistycyzm miłości w «De virginitate» św. Grzegorza z Nyssy, RT 64/4 (2017) s. 23-34. 


\section{Grzegorz Wielki}

-, Homilie na Ezechiela, część pierwsza: Homilie I, 1-12, tt., red. i wstępy A. Wilczyński, ŹrMon 81, Kraków: Wydawnictwo TYNIEC, 2019.

-, Homilie na Ezechiela, część druga: Homilie II, 1-10, tł. i red. A. Wilczyński, wstępy T. Siemieniec, P. Borto, ŹrMon 82, Kraków: Wydawnictwo TYNIEC, 2019.

-, Vita activa. Wybór tekstów z «Moraliów» o życiu czynnym, opr. T. Konsek, Kraków: Wydawnictwo TYNIEC, 2018.

-, Vita contemplativa. Wybór tekstów z «Moraliów» o życiu kontemplacyjnym, opr. T. Konsek, Kraków: Wydawnictwo TYNIEC, 2018.

Lewandowicz J., Klasztory, mnisi, mniszki. Obraz życia monastycznego $w$ «Registrum epistolarum» Grzegorza Wielkiego na tle prawa kościelnego i kościelnego, Kraków: Wydawnictwo TYNIEC, 2018.

Suwiński S., Ideat życia chrześcijańskiego w świetle wybranych pism św. Grzegorza Wielkiego, Toruń: Wydawnictwo Naukowe UMK, 2017.

Szram M., Obraz heretyków w «Moralia in Iob» Grzegorza Wielkiego, VoxP 71 (2019) s. 475-499.

\section{Hermas}

Baron A., Nauka o Duchu Świętym w „, Pasterzu” Hermasa na tle problematyki pneumatologicznej. Studium wprowadzajace. „Polonia Sacra” 23/3 (2019) s. 5-28.

\section{Hezychiusz z Synaju}

-, Wybór tekstów z I tomu Filokalii, tł. C. Dobek, kom. Sz. Hiżycki, Kraków: Wydawnictwo TYNIEC, 2018.

\section{Hieronim}

Bachniak T., Die Regel der Übersetzung nach Hieronymus in der Theorie und Praxis, VoxP 71 (2019) s. 25-42.

Bardski K., Troska Chrystusa o grzeszny Kościót w «Komentarzu do Księgi Sofoniasza» św. Hieronima, CT 87/4 (2017) s. 173-190.

Czyżewski B., Księga proroka Zachariasza w egzegezie Dydyma Aleksandryjskiego i św. Hieronima, VoxP 67 (2017) s. 85-100.

Degórski B., Eretici ed eresie nel «Chronicon» di san Girolamo, VoxP 68 (2017) s. 371- 398. 
Degórski B., Explanationes in Esaiam of St. Jerome. The Outline of its Genesis and Method, BPTh 12/4 (2019) s. 449-468.

Degórski B., Il soggiorno di sant'Ilarione di Gaza in Dalmazia secondo la «Vita S. Hilarionis» di san Girolamo, VoxP 67 (2017) s. 101-114.

Degórski B., La tradizione manoscritta della «Vita S. Pauli Primi Eremitae» e le più antiche edizioni stampate di questa opera geronimiana, VoxP 69 (2018) s. 155-173.

Degórski B., La Vita S. Pauli Monachi Thebaei di san Girolamo contenuta nel codice manoscritto Vaticanus Latinus 13008, VoxP 72 (2019) s. 131-147.

Degórski B., Manoscritti inclassificabili della Vita S. Pauli Monachi Thebaei di san Girolamo, VoxP 71 (2019) s. 131-154.

Degórski B., Spiritualità del monachesimo maschile nelle opere di san Girolamo, VoxP 70 (2018) s. 119-150.

Hood J.Y.B., «Inimici nostri»: Jews as Heretics and Heretics as Judaizers in Jerome and Augustine, VoxP 68 (2017) s. 341-353.

Jóźwiak M., «Fecerunt sibi conflatile de argento suo quasi similitudinem idolorum» Potępienie batwochwalstwa na przykładzie Hieronimowego komentarza do Oz 13,1-14,1, w: Święte wizerunki w przekazie Dobrej Nowiny, red. N. Widok, Opolska Biblioteka Teologiczna 161, Opole: Redakcja Wydawnictw Wydziału Teologicznego Uniwersytetu Opolskiego, 2017, s. 209-220.

Jóźwiak M., «Non intelligis stultitiam tuam impudentiae copulatam». Św. Hieronim contra Pelagiusz, VoxP 68 (2017) s. 399-407.

Jóźwiak M., «Stuga Jahwe» w interpretacji św. Hieronima, VoxP 67 (2017) s. 167-176.

Kołosowski T., Troska o zdrowie chrześcijańskich ascetów w świetle korespondencji św. Hieronima, SaeCh 26/2 (2019) s. 18-27.

Krzyszczuk Ł., «Animalia dubia vel fabulosa» jako przyczynek do polemiki antyheretyckiej w «Komentarzu do Księgi Izajasza» (VI 13, 19 - 14, 1) św. Hieronima, VoxP 68 (2017) s. 409-422.

Krzyszczuk Ł., Kameleon w egzegezie biblijnej św. Hieronima, VV 32 (2017) s. 397-419.

Mateja L., Rozwój wspólnot domowego Kościoła w Ewangelii Marka w świetle «Tractatus in Marci Evangelium» Hieronima ze Strydonu, VoxP 71 (2019) s. 389-405.

Milewski I., Winnica eremity Saby. Uwagi na temat «Vita Hilarionis» (17, 26-27) autorstwa Hieronima ze Strydonu, „Studia Gdańskie” 42 (2018) s. 79-86.

Wysocki M., Hope Found, Hope Lost - Eschatological Aspects in the Interpretations of Israelites' Wilderness Wanderings. Two Sides of One Story: Origen's 27. «Homily on the Book of Numbers» and Jerome's «Letter» 78, VoxP 67 (2017) s. 726-742.

\section{Hieronim (Pseudo-)}

-, Zwięzły komentarz do Księgi Psalmów, Ps 21 (Breviarium in Psalmos, Ps 21), wstęp, tł. i kom. M. Jóźwiak, BPTh 10/4 (2017) s. 493-507. 


\section{Hilary z Poitiers}

-, Traktat do Psalmu 118, wpr., tłum. i red. T. Kołosowski, PSP 69, Warszawa: Wydawnictwo Naukowe UKSW, 2017.

Bodrožić I. - Kraft Soić V., Heretical Doctrine of Photinus of Sirmium in Hilary of Poitiers' «De Trinitate», VoxP 68 (2017) s. 283-314.

\section{Hipolit Rzymski}

Schneider S., Św. Hipolit o greckich misteriach. Misteria we Flius. Misteria w Eleusis. Misteria Rei-Cybeli, Sandomierz: Wydawnictwo Armoryka, 2017 (reprint wydania: Kraków: b.w., 1917).

\section{Ildefons z Toledo}

-, Pouczenie o chrzcie, tł. A. Strzelecka, wstęp P. Wygralak, POK 33, Poznań: Wydział Teologiczny UAM, 2018.

Wygralak P., Chrystus i Jego dzieło zbawcze w chrzcielnym nauczaniu Ildefonsa z Toledo, VoxP 71 (2019) s. 531-541.

\section{Innocenty I, papiė}

-, List do Decencjusza, biskupa Gubbio, wstęp, tł. i kom. W. Turek, Fontes scrutari 3, Torun: Wydawnictwo Naukowe UMK, 2017.

Turek W., «Episcopus», «presbyter», «sacerdos», «diaconus»: niektóre wyjaśnienia papieża Innocentego I w Liście do Decencjusza, biskupa Gubbio, VoxP 67 (2017) s. $653-671$.

\section{Ireneusz z Lyonu}

-, Adversus Haereses, t1. J. Brylowski, Pelplin: Wydawnictwo Bernardinum, 2018.

Artemi E., The Heretic Gnostic and the Real «Gnostic» in Christ According to the Teaching of Irenaeus of Lyon, VoxP 69 (2018) s. 39-52.

Springer D.W., Tell Us No Secrets: St. Irenaeus' Contra-Gnostic Doctrine of Communion, VoxP 68 (2017) s. 85-94.

Zhukovskyy V., Божа велич і провидіння в богослов '̈ Іринея Ліонського, VoxP 69 (2018) s. 755-770. 


\section{Izaak Syryjczyk}

Żyłkowie D. i B., Ślady oralności w Stowach św. Izaaka Syryjczyka na tle rosyjskiej tradycji duchowej, w: Magia Ksiag - Księgi Magii [1], s. 147-158.

\section{Izajasz Anachoreta}

-, Świętego Izajasza Anachorety o straży umystu, tł. C. Dobak, w: Pseudo-Antoni Wielki, Izajasz Anachoreta, Wybór tekstów z I tomu «Filokalii», red. i kom. Sz. Hiżycki, Kraków: Wydawnictwo TYNIEC, 2017, s. 109-124.

\section{Izydor Sewilli}

-, Historia Gotów, Wandalów i Swebów oraz kroniki wczesnośredniowiecznej Hiszpanii [Hydacjusz z Lemiki, Kronika po Hieronimie; Maksymus z Saragossy, Kronika Saragoska; Kronika krółów wizygockich; Chronologia królów Gotów; Alfons III, Kronika „,do Sebastiana”], tł., wstęp i opr. A. Foryt, Kraków: Wydawnictwo Avalon, 2017.

-, O rzekach (Etymologiae XIII, 21), tł., wstęp i kom. E. Kaczyńska, VoxP 71 (2019) s. 631-658.

-, Synonimy, tł., wprow. i opr. T. Krynicka, ŹMT 78, Kraków: Wydawnictwo WAM, 2017. Krynicka T., Izydor z Sewilli, «Synonimy»: tematyka, styl, źródta dzieła, VoxP 69 (2018) s. 405-427.

\section{Jan Chryzostom}

-, Homilie do Drugiego Listu św. Pawła Apostoła do Koryntian (Hom. 1-3) (In epistulam II ad Corinthios argumentum et homiliae 1-3, CPG 4429), wstęp, tł. i kom. A. Paciorek, VoxP 70 (2018) s. 601-638.

-, Homilia XV do Drugiego Listu św. Pawta do Koryntian (2 Kor 7,8-13), tł. A. Paciorek, w: Scripturae Lumen - Wtajemniczenie chrześcijańskie, red. G.M. Baran - J. Królikowski - P. Łabuda, Tarnów: Wydawnictwo BIBLOS, 2018, s. 597-608.

-, Homilie do Drugiego Listu św. Pawła Apostoła do Koryntian, tł., wprow. i przyp. A. Paciorek, Biblia Ojców 1, Częstochowa: Edycja Świętego Pawła, 2019.

-, VII Homilia w cyklu «Homilii do Listu do Filipian», tł. wstęp i kom. Z. Latawiec, VoxP 71 (2019) s. 611-630.

-, Mowy o posagach, tł, wstęp i opr. J. Iluk, Gdańsk: Wydawnictwo Uniwersytetu Gdańskiego, 2017. 
Dera M., Działanie Ducha Świętego w życiu chrześcijanina na podstawie wybranych homilii św. Jana Chryzostoma, „Polonia Sacra” 23/3 (2019) s. 29-40.

Grzywa A., Chrzest jako duchowe matżeństwo w nauczaniu Jana Chryzostoma, RBL 72/1 (2017) s. 5-15.

Iluk J., Bizantyjskie eklogi z homilii św. Jana Chryzostoma i ich nowożytne losy, w: Magia Ksiag - Księgi Magii [1], s. 41-54.

Krynicka T., Jan Chryzostom o chrześcijańskim wychowaniu (na podstawie Homilii 21 na List do Efezjan), w: W kregu antycznych politei [1], s. 195-205.

Olinyk A., St. John Chrysostom and St. Thomas Aquinas on Private Property, BPTh 12/3 (2019) s. 243-254.

Szczur P., Głód jako problem ekonomiczny i społeczny w świetle nauczania homiletycznego Jana Chryzostoma, VoxP 69 (2018) s. 595-610.

Szczur P., Image and Metaphor of the Sea in the «Homilies on the Gospel of Saint Matthew» by John Chrysostom, VoxP 70 (2018) s. 527-544.

Szczur P., Jan Chryzostom obrońcą zgodności przekazu ewangelistów i harmonii Ewangelii, w: Dla dobra Jego Ciała, którym jest Kościół (Kol 1,24) [1], s. 399-417.

Szczur P., Jan Chryzostom o śpiewie i muzyce. Zarys problematyki, VoxP 67 (2017) s. 599-618.

Szczur P., Wyjątkowość pozycji świętego Piotra w Kościele na podstawie wypowiedzi Jana Chryzostoma, w: Wyjątkowość Kościoła katolickiego, red. A.A. Napiórkowski, Cracoviensis cogitatio Ecclesiae 9, Kraków: Uniwersytet Papieski Jana Pawła II, 2018, s. 188-207.

\section{Jan Chryzostom (Pseudo-)}

-, Mowy o poście 1-7, tł. M. Przyszychowska, w: Post jako praktyka duchowa. Ojcowie Kościoła o poście [1], s. 111-133.

-, Na początek postu, tł. L. Nieścior, w: Post jako praktyka duchowa. Ojcowie Kościoła o poście [1], s. 135-140.

\section{Jan z Dalijata}

Uciecha A., Teologiczne podstawy monastycznej mistyki nestoriańskiej (syro-orientalnej) w Listach Jana z Dalijata, VoxP 70 (2018) s. 281-294.

\section{Jan Damasceński}

-, Rozprawa Saracena i Chrześcijanina, tł., wstęp i kom. Ł. Karczewski, VoxP 71 (2019) s. $659-680$. 
Feliga P., Obrona kultu obrazów w «Trzech mowach apologetycznych przeciwko tym, którzy odrzucaja święte obrazy» św. Jana Damasceńskiego, CT 87/3 (2017) s. 25-66.

Feliga P., Wcielenie jako argument na rzecz obrony kultu obrazów w «Trzech mowach apologetycznych przeciwko tym, którzy odrzucaja święte obrazy» św. Jana Damasceńskiego, SPelp 52 (2018) s. 125-139.

Keith Z.M., John of Damascus: Rewriting the Division of Heresy and Schism, VoxP 68 (2017) s. 501-512.

Sordyl K., Bóg i tajemnica człowieka. Antropologia teologiczna św. Jana Damasceńskiego na podstawie «Wykładu wiary prawdziwej», Warszawa: Wydawnictwo Naukowe Sub Lupa, 2019.

\section{Jan Damasceński (Pseudo-)}

-, Historia o Barłaamie i Jozafacie. Opowieść bizantyjska, tł. H. Pietruszczak, Zgorzelec: Wydawnictwo Henryk Pietruszczak, 2018.

\section{Jan Filiponos}

-, Jana z Aleksandrii objaśnienia do drugiej księgi «O duszy», w: Jan Filiponos, Komentarz do Arystotelesowego «O duszy» II, 1-5. (Pseudo-) Symplicjusz, Komentarz do Arystotelesowgo «O duszy» II, 1-5, tł., wstęp i przyp. J. Komorowska, Warszawa: Wydawnictwo Naukowe UKSW, 2018, s. 17-144.

\section{Jan Kasjan}

-, O grzechu i pokucie: Rozmowa XX $i$ XXIII, tł. A. Wilczyński, Z Tradycji Mniszej 63, Kraków: Wydawnictwo TYNIEC, 2017.

-, Rozmowy z Ojcami, tom 3: Rozmowy XVIII-XXIX, tł. A. Wilczyński, ŹrMon 80, Kraków: Wydawnictwo TYNIEC, 2017.

Hiżycki Sz., Trzy twarze gniewu. Jak Jan Kasjan pisat na nowo o starym temacie, VV 34 (2018) s. 315-335.

Misiarczyk L., Źródła ośmiu głównych wad w „,Rozmowach z Ojcami” Jana Kasjana, „Studia Płockie” 46 (2019) s. 7-19.

Nehring P., Dwie monastyczne koncepcje - o tym co łaczy a zarazem dzieli Jana Kasjana iśw. Augustyna, VoxP 69 (2018) s. 527-545.

Rudzinskyi L.V., Źródła autorytetu w «Rozmowach z Ojcami» św. Jana Kasjana, Kraków: Wydawnictwo TYNIEC, 2017. 


\section{Jan Klimak}

Nieścior L., Walka z gniewem - ósmy stopień «drabiny rajskiej» św. Jana Klimaka, VV 33 (2018) s. 343-364.

\section{Jan Moschos}

-, Łąka duchowa. Napisana przez Jana Moschusa, ttumaczona przez Ambrożego Kamaldulensa, tł. H. Pietruszczak, Zgorzelec: Wydawnictwo Henryk Pietruszczak, 2018.

\section{Józef Flawiusz}

Bejda W., Monarchia biblijna w «Starożytnościach Żydowskich» Józefa Flawiusza w porównaniu z żydowska literatura drugiej światyni i pismami rabinicznymi, Wrocław: Wydawnictwo TUM Wrocławskiej Księgarni Archidiecezjalnej, 2018.

\section{Józef Hazzāyā}

Havryluk I., La tappe della vita spirituale: Giuseppe Hazzāyā e l'eredità ascetica greca, VoxP 71 (2019) s. 233-254.

Havryluk I., L'insegnamento «ereticale» sulla visione di Dio nelle opere di Giuseppe Hazzāyā, mistico siro-orientale del secolo VIII, VoxP 68 (2017) s. 535-549.

\section{Justynian}

-, Digesta justyniańskie, t. 7/1: Ksieggi 45-47, red. T. Palmirski, tł. K. Hilman - M. Hładyszewska - T. Palmirski - A.M. Wasyl - J. Zabłocki - J. Krzynówek - J. Reszczyński, Kraków: Poligrafia Salezjańska, 2017.

-, Digesta justyniańskie, t. 7/2: Ksieggi 48-50, red. T. Palmirski, tł. K. Hilman - M. Hładyszewska - P. Niczyporuk - T. Palmirski - A.M. Wasyl - P. Kołodk - P. Kubiak - A. Pikulska-Radomska - J. Reszczyński, Kraków: Poligrafia Salezjańska, 2017. 


\section{Kasjodor Senator}

-, Variae (I-XII), tt. A. Kołtunowska [Przedmowa, Księgi I-V, IX, R. Sawa Księgi VI-VIII, X-XII], opr. M. Ożóg - H. Pietras, SCL 11, ŹMT 79, Kraków: Wydawnictwo WAM, 2017 (edycja dwujęzyczna).

\section{Klemens Aleksandryjski}

Di Paolo M.L. - Limone V., Airesis and airetikoi in the Alexandrine School of the II and III centuries (Clement of Alexandria and Origen), VoxP 68 (2017) s. 73-84.

Kuderski K., Funkcje i znaczenie serca w teologii św. Klemensa z Aleksandrii, „E-Patrologos" 3/2 (2017) s. 105-116.

Mrugalski D., Bóg niezdolny do gniewu. Obrona «apathei» Boga w teologii aleksandryjskiej: Filon, Klemens i Orygenes, VV 33 (2018) s. 279-314.

Mrugalski D., Metamorfozy platońskiej «metafory stońca» (Respublica 509b) w hetero$i$ ortodoksyjnej teologii (I-III w.): Gnostycyzm, Klemens z Aleksandrii i Orygenes, VoxP 68 (2017) s. 21-58.

Szczur P., Walentyniańska interpretacja biblijnego opisu stworzenia czlowieka (Rdz 1, 26-27) w przekazie Klemensa Aleksandryjskiego, VoxP 68 (2017) s. 59-71.

\section{Konstytucje Apostolskie}

Kieling M., Geneza herezji i postawa wobec heretyków na podstawie «Konstytucji apostolskich», VoxP 71 (2019) s. 271-289.

\section{Laktancjusz}

-, O Bożym dziele stworzenia, wstęp, tt. i opr. M. Jesiotr, PSP 72, Warszawa: Wydawnictwo Naukowe UKSW, 2019.

\section{Leon Wielki}

Pietras H., Leone Magno retractavit»? Il cambiamento del linguaggio cristologico del papa dopo il concilio di Calcedonia, OCP 84/1 (2018) s. 82-97. 


\section{Libri poenitentiales}

Kieling M., Celebracje mszy świętych na podstawie «Libri poenitentiales», w: Ojcowie Kościoła o Eucharystii, red. P. Wygralak, Teologia Patrystyczna 14, Poznań: Wydział Teologiczny, 2017, s. 187-203.

Kielig M., Zasady ogólne dotyczace praktyk pokutnych na podstawie «Libri Poenitentiales», VoxP 67 (2017) s. 225-240.

\section{List do Diogneta}

Terka M., Miejsce chrześcijan w świecie w świetle Listu do Diogneta oraz $w$ kontekście antycznej idei pòlij, ,Veritati et Caritati” 11 (2018) s. 33-72.

\section{Liutprand z Cremony}

-, Antapodosis, tł. H. Pietruszczak, Zgorzelec: Wydawnictwo Henryk Pietruszczak, 2019.

\section{Maksym z Turynu}

-, Homilie na rok liturgiczny, tł., wstęp i opr. J. Januszewski, BOK, Kraków: Wydawnictwo m, 2019.

Januszewski J., Homerycki mit o syrenach $w$ «Sermo XXXVII» św. Maksyma z Turynu, „E-Patrologos" 3/1 (2017) s. 50-62.

\section{Maksym Wyznawca}

Clarke K.M., Preserving the Whole Theological System: Maximus the Confessor's Dyothelitism as a Bulwark for Trinitarian Theology, Christology, and Soteriology, VoxP 68 (2017) s. 479-500.

Hupalo М., «Логоси» у вченні св. Максима Ісповідника як епістемологічні принциипи стосунку Бога з людиною і світом, VoxP 67 (2017) s. 149-165.

Kashchuk O., Holy Scripture in the Monothelite Controversy. The Standpoint of Maximus the Confessor, VoxP 68 (2017) s. 465-477.

Kochańczyk-Bonińska K., Odpowiedzialność człowieka za świat stworzony wedtug Maksyma Wyznawcy, VV 31 (2017) s. 269-281.

Kosmulska B., Filautía w pismach św. Maksyma Wyznawcy, „E-Patrologos” 3/2 (2017) s. $56-73$. 
Wojciechowski J., Ontologia aktów chcenia i poznania wedtug św. Maksyma Wyznawcy jako przyczynek do rozumienia relacji natury i łaski, WST 32/1 (2019) s. 26-42.

\section{Marek Diakon}

Milewski I., Pieniądz w «Vita Porphyrii episcope Gazensis» pióra Marka Diakona, „Studia Gdańskie" 40 (2017) s. 35-42.

\section{Marek Eremita (Mnich)}

-, O poście (De ieiunio, CPG 6099), wstęp K. Żółtaszek, kom. i tł. M. Warzocha - K. Żółtaszek, VoxP 67 (2017) s. 811-823.

-, Dziełko dziewiąte: o poście, tł. M. Warzocha-K. Żółtaszek, w: Post jako praktyka duchowa. Ojcowie Kościoła o poście [1], s. 87-90.

-, Rozmowa z prawnikiem (Disputatio cum quodam causidico, CPG 6097), tł. Z. Latawiec - M. Warzocha - K. Żółtaszek, wstęp Z. Latawiec - K. Żółtaszek, kom. M. Warzocha, VoxP 69 (2018) s. 863-902.

Czyżewski B., Wolność i łaska w nauce Marka Eremity, CT 89/1 (2019) s. 75-88.

Escure-Delpeuch É., Modlitwa wedlug Marka Eremity, CT 89/1 (2019) s. 33-50.

Grzywaczewski J., Zagadnienie Kościoła w kontekście ascetycznym u Marka Eremity, CT 89/1 (2019) s. 51-74.

Grzywaczewski J. - Nieścior L., Marek Eremita: biografia i bibliografia, CT 89/1 (2019) s. 5-14.

Kamczyk W., Duchowe i moralne implikacje chrztu wedtug św. Marka Eremity, CT 89/1 (2019) s. 15-32.

Nieścior L., Namiętności i walka z nimi wedtug Marka Eremity, CT 89/1 (2019) s. 101-114. Patrin W., Nauka św. Marka Eremity o cnocie, CT 89/1 (2019) s. 89-100.

\section{Martyrologium Romanum}

Nocoń A. Męczennicy Afryki Pótnocnej w «Martyrologium Rzymskim», VoxP 72 (2019) s. 49-66.

\section{Menas, męczennik egipski}

Piwowarczyk P., Greckie i koptyjskie «Męczeństwo» św. Menasa. Wstęp i przekład z komentarzem, SSHT 51/2 (2018) s. 361-375. 


\section{Metody z Olimpu}

Mejzner M., La difesa dell'identità del corpo risorto con quello terreno nel «De resurrection» di Metodio di Olimpo, VoxP 67 (2017) s. 403-422.

Mejzner M., Methodius: millenarist or anti-millenarist?, w: Methodius of Olympus. State of the art and new perspectives, ed. K. Bracht, Textes und Untersuchungen, Berlin: De Gruyter 2017, s. 63-84.

Mejzner M., Metody z Olimpu, NSWP, s. 704-706.

Mejzner M., Undem malum? w «De autexusio» Metodego z Olimpu, BPTh 10/1 (2017) s. 101-118.

\section{Nil z Ancyry}

Nieścior L., Ślady egzegezy Filona Aleksandryjskiego $w$ «De monastica exercitatione» Nila z Ancyry, VoxP 70 (2018) s. 25-44.

Nieścior L., Ślady Orygenesowej egzegezy w «De monastica exercitatione» Nila z Ancyry, VoxP 71 (2019) s. 407-422.

\section{Nonnos z Pentapolis}

-, Walka Tyfoeusa z bogami. Nonnos, «Dionysiaka» I 154-534, tł. i wstęp K. Kryńska, „Meander” 73 (2018) s. 53-76

Stępień P., Wzorce wyrazowe w „Dionysiaca” Nonnosa, Poznań: Wydawnictwo Naukowe UAM, 2018.

\section{Nowacjan}

Mrugalski D., Nieskończoność Boga u Nowacjana: Prawdopodobne źródła greckie, „Przegląd Tomistyczny” 23 (2017) s. 147-181.

\section{Ody Salomona}

Jutkiewicz P., «Otwórzcie uszy wasze, a będę mówił do was» Ody Salomona 9, 14, 28, 32 i 34, WST 32/2 (2019) 138-154. 


\section{Ojcowie Apostolscy}

Kowalski A., Źródta pojęcia osoby w pismach Ojców Apostolskich, Kielce: Wydawnictwo Jedność, 2017.

\section{Orozjusz}

Skibiński T., The Thunderbolt as a Sign of God in Orosius" "Seven Books of History against the Pagans», SaeCh 24 (2017) s. 17-27.

\section{Orygenes}

-, Komentarze do Księgi Przysłów, wstęp, tł. i opr. P. Szewczyk, PSP 71, Warszawa: Wydawnictwo Naukowe UKSW, 2019.

Di Paolo M.L. - Limone V., Airesis and airetikoi in the Alexandrine School of the II and III centuries (Clement of Alexandria and Origen), VoxP 68 (2017) s. 73-84.

Grzywaczewski J., Święty Józef jako opiekun Jezusa i malżonek Maryi wedtug Orygenesa, VoxP 71 (2019) s. 209-232.

Kluz W., Otwartość na kultury wyrazem powszechności Kościoła w nauce Orygenesa, „E-Patrologos" 4/1 (2019) s. 5-16.

Kluz W., Spotkanie wiary i kultury w koncepcji Orygenesa, „E-Patrologos” 3/1 (2017) s. $28-49$.

Królikowski J., Orygenes i hebrajski tekst Pisma Świętego, VoxP 69 (2018) s. 393-404.

Misiarczyk L., Origen as a Source of Evagrian eight passionate thoughts, „Seminare” 39/4 (2018) s. 191-205.

Mrugalski D., Bóg niezdolny do gniewu. Obrona «apathei» Boga w teologii aleksandryjskiej: Filon, Klemens i Orygenes, VV 33 (2018) s. 279-314.

Mrugalski D., Metamorfozy platońskiej «metafory słońca» (Respublica 509b) w heteroi ortodoksyjnej teologii (I-III w.): Gnostycyzm, Klemens z Aleksandrii i Orygenes, VoxP 68 (2017) s. 21-58.

Mrugalski D., Nieskończoność Boga u Orygenesa: Przyczyna wielkiego nieporozumienia, VoxP 67 (2017) s. 437-475.

Mrugalski D., «Potentia Dei absoluta et potentia Dei ordinata» u Orygenesa? Nowa próba wyjaśnienia kontrowersyjnych fragmentów «De Principiis», VoxP 69 (2018) s. 493-526.

Mrugalski D., Stwarzanie wieczne i poza czasem: Filozoficzne źródła koncepcji «generatio aeterna» Orygenesa, VV 35 (2019) s. 373-412.

Nieścior L., Ślady Orygenesowej egzegezy w «De monastica exercitatione» Nila z Ancyry, VoxP 71 (2019) s. 5-20. 
Osek E., Uczta demonów: Orygenesa «Contra celsum» VIII 30 i Porfiriusza «De abstinentia» II 42-43, VoxP 69 (2018) s. 547-560.

Pietras H., La speranza escatologica di Origene, w: Nadzieje upadajacego świata. Nadzieja w chrześcijańskiej epistolografii łacińskiej IV i V wieku (Ambroży, Augustyn, Hieronim, Paulin z Noli), red. M. Wysocki - J. Pałucki - M. Pyzik-Turska, Lublin: Wydawnictwo KUL, 2019, s. 199-216.

Romanek J., Droga do świętości w rozumieniu Orygenesa, RT 64/4 (2017) s. 5-22.

Szram M., Nowotestamentalny paradoks mocnej słabości w egzegezie biblijnej Orygene$s a$, VoxP 69 (2018) s. 611-621.

Szram M., Świat myśli Orygenesa, NSWP, s. 757-761.

Wendlik K., Serce to umyst. Mistyka spotkania Boga i człowieka w ujęciu Orygenesa oraz św. Augustyna - inspiracje IV Ewangelii, Kraków: Wydawnictwo Wejdźmy na szczyt, 2017.

\section{Palladiusz}

Milewski I., Pieniadz $w$ «Historia Lausiaca» autorstwa Palladiusza z Helenopolis, VoxP 67 (2017) s. 423-435.

\section{Passio ss. Perpetuae et Felicitatis}

Stawoska-Jundziłł B., Rodzina a wiara $w$ «Passio SS. Perpetuae et Felicitatis», VoxP 67 (2017) s. 555-572.

\section{Paulin z Noli}

-, Listy 1-51, tł., opr. i wst. M. Wysocki - J. Pałucki - M. Pyzik-Turska, ŹMT 82, Kraków: Wydawnictwo WAM, 2019.

Degórski B., Il pasto per i poveri presso la Basilica Costantiniana di S. Pietro a Roma secondo la lettera di san Paolino di Nola a san Pammachio, BPTh 11/2 (2018) s. 229-267.

Degórski B, Uczta dla biedaków w Konstantyńskiej Bazylice św. Piotra w Rzymie na podstawie listu św. Paulina z Noli do św. Pammachiusza, „Dissertationes Paulinorum” 27 (2018) s. 5-35.

Krawczyk M. The visual image in the life of St. Paulinus of Nola, „Studia Leopoliensia” 12 (2019) s. 197-203.

Pałucki J., Laska Boża i jej nieodzowna pomoc w utrzymaniu nadziei w codziennym życiu człowieka na przykładzie pism Paulina z Noli, VoxP 67 (2017) s. 499-508. 


\section{Pawel Diakon}

Conti M., Humanistic aspects of Carolingian Court Poetry: Poetical Technique and Use of Sources in Paul the Deacon's «Carmen X», SaeCh 24 (2017) s. 47-53.

\section{Pelagiusz}

-, Pisma, tł. A. Smaroń - J. Mrukówna, wstęp i red. J. Pochwat, Kraków: Wydawnictwo La Salette, 2017 (zawiera teksty: CPL 732; 733; 734; 735; 736; 748; 749; 755; 756; 756a). -, Komentarz do Listów św. Pawła, tł. F. Czarnota - J. Pochwat, red. A. Baron - J. Pochwat, Kraków: Wydawnictwo La Salette, 2018.

Jóźwiak M., «Non intelligis stultitiam tuam impudentiae copulatam». Św. Hieronim contra Pelagiusz, VoxP 68 (2017) s. 399-407.

\section{Piotr Chryzolog}

-, Mowy VII-IX, tł. M. Przyszychowska, w: Post jako praktyka duchowa. Ojcowie Kościota o poście [1], s. 91-101.

Kochaniewicz B., Demonologia w «Sermones»św. Piotra Chryzologa, PST 34 (2019) s. 131-148.

\section{Prudencjusz Aureliusz Klemens}

-, Utwory poetyckie: Kathemerinon; Apotheosis; Hamartigenia; Psychomachia; Przeciw Symmachowi (księga I i II) wraz z Relatio Symmacha i listami św. Ambrożego; Dittochaeon, tł. M. Brożek - P. Nowak (Relatio Symmacha i listy św. Ambrożego), opr. M. Starowieyski, ŹMT 81, Kraków: Wydawnictwo WAM, 2019.

Pyzik-Turska M., Obraz heretyka w «Liber Apotheosis» Aureliusza Prudencjusza Klemensa, VoxP 68 (2017) s. 457-464.

\section{Pseudo-Dionizy Areopagita}

Manikowski M., Warunki doświadczenia mistycznego wedtug Pseudo-Dionizego Areopagity. Ujęcie filozoficzne, „Filozofia Chrześcijańska” 15 (2018) s. 9-30.

Niziński R.S., Aspekt negatywny doświadczenia mistycznego u Dionizego Areopagity oraz św. Jana od Krzyża. Różnice i podobieństwa, ,Studia Redemptorystowskie” 17 (2019) s. 113-136. 
Switkiewicz-Blandzi A., Pseudo-Dionizy a Grzegorz Palamas. Bizantyjska synteza wschodniej patrystyki, Warszawa: Wydawnictwo Naukowe Sub Lupa, 2018.

\section{Prokopiusz z Cezarei}

-, Anékdota, tł. H. Pietruszczak, Zgorzelec: Wydawnictwo Henryk Pietruszczak, 2019.

-, Wojna wandalska, tł. H. Pietruszczak, Zgorzelec: Wydawnictwo Henryk Pietruszczak, 2018.

\section{Quodvultdeus}

Voprada D., Quodvultdeus' Sermons on the Creed: A Reassessment of His Polemics Against the Jews, Pagans, and Arians, VoxP 68 (2017) s. 355-369.

\section{Raban Maur}

-, Poezje (wybor), tł., wstęp i kom. T. Gacia, VoxP 71 (2019), s. 681-692.

\section{Ratramnus z Korbei}

-, List o psiogłowych Ratramnusa z Korbei, (PL 121, 1153-1156) tł., wstęp i przyp. M. Chudzikowska-Wołoszyn, ,Zeszyty Naukowe Ostrołęckiego Towarzystwa Naukowego" 32 (2018) s. 293-309.

\section{Regula Mistrza}

Czyżewski B., „Reguła Mistrza” o wyborze i nauczaniu opata, VoxP 70 (2018) s. 243-258. Czyżewski B., Wskazania dla mnichów w komentarzu do Modlitwy Pańskiej w „Regule Mistrza”, VoxP 69 (2018) s. 143-154.

\section{Reguly monastyczne}

Wczesne reguły monastyczne w Galii, tł. K. Bielawski, wstęp J. Piłat, ŹrMon 3, wyd. 2, Kraków: Wydawnictwo TYNIEC, 2018. 


\section{Roman Melodos}

-, Kontakion na święto «Spotkania Pana» - «Ofiarowania Jezusa w Świątyni Jerozolimskiej» (Contacium in Hypapante Domini, CPG 7570; hymn 14), tł., wstęp i kom. B. Degórski, VoxP 70 (2018) s. 639-657.

Degórski B., Maria nel contacio di san Romano il Melode per la Presentazione di Gesù al Tempio, „Angelicum” 95 (2018) s. 487-511.

Dźwigała K.M., Romanos the Melodist as a Teacher of the People in the Struggle Against Heresies, VoxP 68 (2017) s. 513-521.

\section{Sergiusz Stylita}

Żelazny J., Klęski militarne jako wyraz gniewu Boga w «Dialogu przeciwko Żydowi» Sergiusza Stylity, VV 33 (2018) s. 365-383.

\section{Sewer z Antiochii}

-, Homilie katedralne [fragm. hom. 20; hom. 77; hom. 104], tł. A. Uciecha, w: Ewangelia wedtug św. Mateusza 14-28, OKKB NT 1b, red. T. Skibiński, Ząbki 2018, s. 128-129 (Łagodny król) i 130-131 (Słali gałazki palm); s. 314-315 (Po upływie szabatu); s. 152 (Drogi Bożej w prawdzie nauczasz) i 152-153 (Czemu wystawiacie mnie na próbę).

\section{Sewerus z Minorki}

Uciecha A., Kult relikwii świętego Szczepana i nawracanie Żydów na podstawie „Epistula Severi", SSHT 51/1 (2018) s. 64-75.

\section{Sofroniusz z Jerozolimy}

Kashchuk O., Sophronius, a Monk of Palestine, and Miaenergism. The Tension Between Exactness and Ambiguity, VoxP 70 (2018) s. 259-280.

\section{Sokrates Scholastyk}

Bralewski S., Cesarzowa Helena, matka Konstantyna Wielkiego w ujęciu Sokratesa z Konstantynopola i Hermiasza Sozomena, w: W kręu antycznych politei [1], s. 49-57. 


\section{Sozomen}

Bralewski S., Cesarzowa Helena, matka Konstantyna Wielkiego w ujęciu Sokratesa z Konstantynopola i Hermiasza Sozomena, w: W kręu antycznych politei [1], s. 49-57.

\section{Sulpicjusz Sewer}

-, Kroniki, tł. P.J. Nowak, wstęp i red. J. Pochwat, ŹrMon 79, Kraków: Wydawnictwo TYNIEC, 2017.

Pochwat J., Oblicza śmierci człowieka w myśli Sulpicjusza Sewera, VoxP 67 (2017) s. 509-522.

\section{Teodor z Mopsuestii}

Grzywa A., Motyw eschatologiczny w rytach katechumenalnych i chrzcielnych na przykładzie homilii katechetycznych Teodora z Mopsuestii, RBL 70/3 (2017) s. 245-258.

\section{Teodor Studyta}

Bеу I., Филаутиа в «Великом Оглашении» преп. Феодора Cтудита, „E-Patrologos” 3/2 (2017) s. 90-104.

\section{Teodoret z Cyru}

-, Historia Kościoła, t1. H. Pietruszczak, Zgorzelec: Wydawnictwo Henryk Pietruszczak, 2019.

Dobosz W,. Rozum jako naturalna droga do wiary - zapomniana koncepcja Teodoreta z Cyru, VoxP 71 (2019) s. 155-184.

Milewski I., Pieniadz $w$ «Historia religiosa» autorstwa Teodoreta z Cyru, VoxP 69 (2018) s. 481-492.

\section{Teoderyk Wielki}

-, Edykt króla Teoderyka, tł. A. Caba - M. Ożóg, wstęp i przyp. M. Ożóg, Biblioteka Przekładów z Literatury Antycznej 20, Kraków: Wydawnictwo PAU, 2018.

Ożóg M., Rozporządzenia prawne Teoderyka Wielkiego $w$ kwestiach religijnych $w$ «Variae» Kasjodora, w: Rzymianie i barbarzyńcy [1], s. 169-188. 


\section{Teofilakt Simokatta}

Kotłowska A., «Dialog filozofii z historią»: zagadkowy wstęp do «Historii powszechnej» Teofilakta Simokatty, VoxP 70 (2018) s. 297-309.

\section{Tertulian}

-, Przeciw Hermogenesowi, tł. A.M. Filipowicz, w: Tertulian przeciwko Hermogenesowi, czyli spór o stworzenie świata, Warszawa, Wydawnictwo Naukowe UKSW, 2018, s. 139-209.

Filipowicz A.M., Tertulian przeciwko Hermogenesowi, czyli spór o stworzenie świata Warszawa, Wydawnictwo Naukowe UKSW, 2018.

Turek W., Jakimi językami postugiwali się starożytni chrześcijanie Afryki Północnej? Analiza odnośnych tekstów Tertuliana, św. Cypriana i św. Augustyna, VoxP 72 (2019) s. 27-48.

Zalewski D., Rola i zadania prezbiterów we wspólnocie kościelnej w świetle pism Tertuliana, VoxP 72 (2019) s. 67-77.

\section{Tymoteusz I, katolikos}

Żelazny J., Biblijne uzasadnienie prymatu Biskupa Orientu na podstawie listów Tymoteusza I, patriarchy Bagdadu, VoxP 67 (2017) s. 779-788.

Żelazny J., Cyprian u Tymoteusza. Odwołania do decyzji synodalnych Cypriana z Kartaginy w polemice w Kościele Orientalnym w VIII wieku, VoxP 72 (2019) s. 121-130.

\section{Vitae Patrum}

Vitae Patrum. Żywoty Ojców, tł. H. Pietruszczak, Zgorzelec: Wydawnictwo Henryk Pietruszczak, 2018.

\section{Wenancjusz Fortunatus}

-, Poezje. Wybór, tł., wstęp i objaśnienia T. Gacia, Lublin: Towarzystwo Naukowe KUL, 2018 (edycja dwujęzyczna).

-, Wiersze opisowo-laudacyjne (Carmina I 19; I 20; III 12, CPL 1033), t1. J. Adamiak A. Budzeń - T. Gacia - E. Kowalczyk - D. Szurgot - N. Turkiewicz, wstęp i kom. T. Gacia, VoxP 67 (2017) s. 825-834 (edycja dwujęzyczna). 


\section{Wiktoryn z Petawium}

Chandoga N.A., Эсхатология святителя Викторина Петавийского: богословскофилологический анализ латинских терминов, VoxP 69 (2018) s. 65-82.

\section{Zenon z Werony}

-, Mowa I, 39 (II, 18) - Na dzień św. Arkadiusza, który narodził się dla nieba 12 stycznia, w mieście Cezarea Mauretańska, tł., wstęp i kom. A. Nocoń, VoxP 71 (2019) s. 593-609.

Kamczyk W., Juda i Tamar (Rdz 38) w alegorycznej egzegezie św. Zenona z Werony, SSHT 51/1 (2018) s. 42-63.

Witos B., Myśl pasterska świętego Zenona z Werony na podstawie jego «Sermones», Kraków: Wydawnictwo scriptum, 2019.

\section{Recenzje}

Bardski K. (rec.), M. Jóźwiak, «Komentarz do historii Hioba» Filipa Prezbitera, Wrocław: Wydawnictwo „Tum” 2015 - VV 31 (2017) s. 351-355.

Beyga P. (rec.), H. Pietras, Herezje, Kraków 2019 - „Teologia w Polsce” 13/2 (2019) S. 281-284.

Block W. (rec.), D. Kasprzak, Kształtowanie się nauki o niebie w teologii patrystycznej I-III wieku, Kraków 2017 - „Polonia Sacra” 22/1 (2018) s. 197-199.

Chrostowski W. (rec.), Nowy słownik teologii biblijnej, red. H. Witczyk, Lublin: Towarzystwo Naukowe KUL - Kielce: Wydawnictwo Jedność, 2017 - VV 32 (2017) s. 487-490.

Czyżewski B. (rec.), J. Grzywaczewski, The Biblical Idea of Divine Mercy in the Early Church, Warszawa: Wydawnictwo Naukowe UKSW, 2016 - VoxP 70 (2018) s. 691-693.

Cwikła J. (rec.), M. Wojciechowski, Dwie wersje Dziejów Apostolskich. Tekst standardowy i zachodni, Kraków 2018 - PST 34 (2019) s. 213-216.

Degórski B. (rec.), Рецензія на книгу «Персоналістична інтерпретація благодаті в універсальному персоналізмі та в догматичному богослів 'ї Чеслава Станіслава Бартніка», in П. Василів, Любов у Христі, Чортків 2018, s. 7-9.

Dziuba A.F. (rec.), A. Varisco, Fides et caritas. Il Beato Gherardo de' Saxo e i 900 anni dell'Ordine di San Giovanni di Gerusalemme, di Rodi e di Malta (con gradi del Sovrano Militare Ordine di Malta e dell'Ordine pro Merito Melitensi civile e militare), Domus templi 4, Arcidossa (GR) 2016 - VoxP 70 (2018) s. 712-716.

Dziuba A.F. (rec.), R. Lane Fox, Augustine: Conversions to Confessions, New York 2015, Basic Books. A Member of the Perseus Books Group - VoxP 70 (2018) s. 685-689. 
Eismant P. (rec.), M. Winiarczyk, Diagoras z Melos - prawda i legenda. Przyczynek do historii antycznego ateizmu, Kraków: Księgarnia Akademicka 2015, ss. 274 - VoxP 68 (2017) s. 678-684.

Filipczak P. (rec.), F. Alpi, La route royale. Sévère d'Antioche et les Églises d'Orient (512518), Bibliothèque archéologique et historique 188, t. 1-2, Beyrouth 2009 - VoxP 68 (2017) s. 605-611.

Groń R. (rec.), A Companion to Aelred of Rievaulx (1110-1167), ed. Marsha L. Dutton, Brill's Companions to the Christian Tradition 76, Leiden - Boston 2017, Brill - VoxP 70 (2018) s. 716-719.

Groń R. (rec.), Aelredi Rievallensis Opera Omnia VI: Opera historica et hagiographica, Turnhout: Brepols Publishers, 2017; Opera Omnia VII: Vita sancti Aedwardi Regis et Confessoris; Vita Sancti Aedwardi versifice, Turnhout: Brepols Publishers 2017 - VoxP 72 (2019) s. 297-302.

Gron R. (rec.), J. Traux, Aelred the Peacemaker: The Public Life of a Cistercian Abbot, Cistercian Studies Series 251, Collegeville MI 2017, Cistercian Publications-Liturgical Press - VoxP 70 (2018) s. 752-756.

Jaworski P. (rec.), Pszczoły, miód, wosk pszczeli w symboliczno-metaforycznych obrazach. Od Biblii poprzez antyk do liturgii Kościoła, red. I. Wieżel - G.M. Baran, Kraków: Wydawnictwo „scriptum”, 2018 - Scripturae Lumen - Wtajemniczenie chrześcijańskie, red. G.M. Baran - J. Królikowski - P. Łabuda, Tarnów: Wydawnictwo BIBLOS, 2018, s. 628-637.

Kochanek P. (rec.), B. Cecota, Arabskie oblężenia Konstantynopola w VII-VIII wieku. Rzeczywistość i mit, Byzantina Lodziensia XXI, Łódź: Wydawnictwo Uniwersytetu Łódzkiego 2015 - VoxP 68 (2017) s. 633-641.

Kochanek P. (rec.), Dietetyka i sztuka kulinarna antyku i wczesnego Bizancjum (II-VII w.), część 1: Zboża i produkty zbożowe w źródlach medycznych antyku $i$ wczesnego Bizancjum (II-VII w.), red. M. Kokoszko - K. Jagusiak - Z. Rzeźnicka, Byzantina Lodziensia XVI, Łódź: Wydawnictwo Uniwersytetu Łódzkiego, 2014 - VoxP 68 (2017) s. 615-633.

Kochanek P. (rec.), Dietetyka i sztuka kulinarna antyku i wczesnego Bizancjum (II-VII w.), część 2: Pokarm dla ciała i ducha, red. M. Kokoszko, Byzantina Lodziensia XIX, Łódź: Wydawnictwo Uniwersytetu Łódzkiego, 2014 - VoxP 70 (2018) s. 659-685.

Kochanek P. (rec.), Dietetyka i sztuka kulinarna antyku i wczesnego Bizancjum (II-VII w.), część 3: Ab ovo ad gala. Jajko, mleko i produkty mleczne w medycynie i sztuce kulinarnej (I-VII w.), Z. Rzeźnicka - M. Kokoszko, Byzantina Lodziensia 28, Łódź: Wydawnictwo Uniwersytetu Łódzkiego, 2016 - VoxP 70 (2018) s. 695-709.

Kochanek P., Ранні Отиі Церкви. Антологіа, за редацією Марії Горячої, Витоки християнства 1: Джерела 1, Львів 2015, Видавництво Українського Католицького Університету - VoxP 68 (2017) s. 668-671.

Kochanek P. (rec.), Софія Київська: Візантія. Русь. Украӥна, Випуск II: Збірка наукових праџь присвячена 150-литтю з дня народження Дмитра Власовича 
Айналова (1862-1939 рр.), відповідальний редактор: П.С. Сохань, упорядники: Д.С. Гордієнко - В.В. Корнієнко, Київ 2012 - VoxP 68 (2017) s. 611-615.

Kochanek P. (rec.), B. Szefliński, Trzy oblicza Sawy Nemanjicia. Postać historyczna - autokreacja - postać literacka, Byzantina Lodziensia XXV, Łódź: Wydawnictwo Uniwersytetu Łódzkiego, 2016, ss. VIII + 342. - VoxP 68 (2017) s. 702-705.

Kochanek P. (rec.), Kazimierz Zakrzewski. Historia i polityka, red. M. Dąbrowska, Warszawa - Łódź: Instytut Pamięci Narodowej - Komisja Ścigania Zbrodni przeciw Narodowi Polskiemu - Uniwersytet Łódzki, 2015 - VoxP 68 (2017) s. 658-668.

Kochańczyk-Bonińska K. (rec.), T. Stępień, Porządek i miłość. Koncepcja Opatrzności Bożej w myśli starożytnej, Warszawa: Teologia Polityczna, 2019 - SPelp 53 (2019) s. 601-603.

Kozłowski M. (rec.), M. Dąbrowska, Drugie oko Europy. Bizancjum w średniowieczu, Wrocław: Wydawnictwo Chronicon 2015 - VoxP 68 (2017) s. 641-647.

Longosz S. (rec.), Św. Izydor z Sewilli, Synonimy, przekład, wprowadzenie i opracowanie Tatiana Krynicka, ŹMT 78, Kraków: Wydawnictwo WAM, 2017 - VoxP 70 (2018) s. 721-723.

Longosz S. (rec.), Św. Jan Chryzostom, Mowy do Antiocheńczyków o posagach, przekład i komentarz Jan Iluk, Gdańsk: Wydawnictwo Uniwersytetu Gdańskiego, 2017 - VoxP 70 (2018) s. 723-726.

Longosz S. (rec.), Kasjodor Senator, Variae, thum. Anna Kołtunowska: Przedmowa + księgi I-V i IX, oraz Robert Sawa: księgi VI-VIII i X-XII; rewizja przekładu i opracowanie: Monika Ożóg - Henryk Pietras SJ, ŹMT 79 = SCL 11, Kraków 2017- VoxP 70 (2018) s. 734-736.

Longosz S. (rec.), W. Stawiszyński, Bibliografia patrystyczna 1901-2016. Polskie thmaczenia tekstów starochrześcijańskich pierwszego tysiąclecia, Tyniec - Kraków 2017 - VoxP 70 (2018) s. 745-748.

Longosz S. (rec.), Tajemnice gnozy: VI kodeks Biblioteki z Nag Hammadi - inny niż wszystkie. Tom poświęcony pamięci Profesor Albertyny Szczudłowskiej-Dembskiej (1934-2013), red. A. Sowińska - W. Stawiszyński, Warszawa: Wydawnictwo Naukowe Sub Lupa, 2016 - VoxP 70 (2018) s. 709-712.

Ludewicz M. (rec.), S. Adamiak, Deo Laudes. Historia sporu donatystycznego, Parnassus 11, Warszawa: Wydawnictwo Sub Lupa, 2019 - VoxP 72 (2019) s. 307-314.

Majewski M. (rec.), A. Tronina, Ksiega Jubileuszy czyli Mała Genesis. Przekład i opracowanie (AST 4; Kraków-Mogilany: The Enigma Press 2018) - VV 35 (2019) s. 565-569.

Nojek P. (rec.), Św. Nicetas z Remezjany, O czuwaniach sług Boga. De vigiliis servorum Dei, wstęp i thum. Magdalena Jóźwiak, Biblioteka Patrystyczna 1, Wrocław: Wydawnictwo TUM Wrocławskiej Księgarni Archidiecezjalnej, 2015 - VoxP 68 (2017) s. 671-674.

Piasecki D. (rec.), Sz. Drzyżdżyk, Chrystologia w perspektywie Mitu Trojańskiego, Horyzonty Dogmatu 3, Kraków: 2017, Wydawnictwo ,scriptum”, 2017 - VoxP 70 (2018) s. $719-720$. 
Piasecki D. (rec.), M. Gilski, Mariologia centonów, Kraków: Wydawnictwo „scriptum”, 2015 - VoxP 70 (2018) s. 689-691.

Pietras H. (rec.), Mort et résurrection dans l'Antiquité chrétienne. De la mort à la vie, l'espérance en la résurrection dans l'Antiquité tardive: histoire, archéologie, liturgie et doctrines. Colloque organisé par la Faculté Antoni Gaudì, Athénée Universitaire Saint Patien (AUSP), Barcelone, 20-21 novembre 2014, Histoire et Théologie, Parole et Silence, éd. R. Barô - A. Viciano - D. Vigne, Paris 2017 - „Gregorianum” 98/4 (2017) s. 853-855.

Pietras H. (rec.), C. dell'Osso, Monoenergiti/monoteliti del VII secolo in Oriente. Prefazione di Claudio Moreschini, SEA 148 - OCP 84/1 (2018) s. 276-277.

Pietras H., Wokót Soboru Nicejskiego ciag dalszy. Kilka precyzacji w odpowiedzi na artykut recenzyjny Sławomira Bralewskiego: Wokót Soboru Nicejskiego (325): na kanwie monografii autorstwa Henryka Pietrasa SJ, [VoxP 65 (2016), s. 75-98] - VoxP 68 (2017) s. 706-714.

Piwowarczyk P. (rec.), Św. Ireneusz z Lyonu, Adversus haereses, tł. J. Brylowski, Pelplin: Bernardinum 2018 - ŚSHT 51/2 (2018) s. 467-471.

Sakowicz E. (rec.), J. Grzywaczewski, The Biblical Idea of Divine Mercy in the Early Church, Warszawa: Wydawnictwo Naukowe UKSW, 2016 - „Studia Nauk Teologicznych PAN" 12 (2017) s. 293-297.

Stawiszyński W. (rec.), J. Lewandowicz, Klasztory, mnisi, mniszki. Obraz życia monastycznego w «Registrum epistolarum» Grzegorza Wielkiego na tle prawa cesarskiego i kościelnego, Kraków: Wydawnictwo TYNIEC, 2018 - VoxP 70 (2018) s. 758-761.

Szarmach M. (rec.), Bazyli Wielki, Pogańscy mistrzowie chrześcijaństwa w przekładzie i opracowaniu Pawła Błażewicza, Warszawa 2017 - „Nowy Filomata” 22/1 (2018) s. 81-83.

Szczur P. (rec.), B. Czyżewski, Piękno chrztu świętego, Kraków - Szydłówek, 2016 VoxP 68 (2017) s. 684-691.

Szczur P. (rec.), P. Filipczak, An introduction to the Byzantine administration in Syro-Palestine on the eve of the Arab conquest, tł. A. Mękarski, Byzantina Lodziensia 26, Łódź 2015 - VoxP 68 (2017) s. 647-651.

Szczur P. (rec.), J. Grzywaczewski, Great Persecutions and the Reconciliation of the Lapsi, Warszawa 2015 - VoxP 68 (2017) s. 652-658.

Szczur P. (rec.), Św. Jan Chryzostom, Mowy do Antiocheńczyków o posagach, przekład i komentarz J. Iluk, Gdańsk 2017 - VoxP 70 (2018) s. 726-734.

Szczur P. (rec.), О. Кащук, Монотелітство у Візантії VII століття: доктрина, політика та ідеологія влади, Львів 2019 - VохР 71 (2019) s. 314-321.

Szczur P. (rec.), W. Stawiszyński, Bibliografia patrystyczna 1901-2016. Polskie thumaczenia tekstów starochrześcijańskich pierwszego tysiąclecia, Tyniec - Kraków 2017 - VoxP 70 (2018) s. 748-751.

Szczur P. (rec.), A. Stępniewska, Matki Ojców Kościoła, Lublin 2015 - VoxP 68 (2017) s. 675-678. 
Szram M. (rec), J. Grzywaczewski, The Biblical Idea of Divine Mercy in the Early Church, Wydawnictwo UKSW, Warszawa 2016 - VoxP 70 (2018) s. 693-695.

Szram M. (rec.), D. Kasprzak OFMCap, Kształtowanie się nauki o niebie w teologii patrystycznej I-III wieku, Kraków 2017 - VoxP 70 (2018) s. 737-740.

Szram M. (rec.), K. Leśniewski, «W samym sobie znaleźliśmy wyrok śmierci: aby nie ufać sobie samemu, lecz Bogu...». Metanoiczno-soteriologiczne przesłanie «Wielkiego kanonu» św. Andrzeja z Krety, Lublin 2017 - VoxP 70 (2018) s. 740-742.

Szram M. (rec.), J. Słomka, Historia duchowości. Czas Ojców Kościoła, Katowice 2017, Wydawnictwo Uniwersytetu Śląskiego - VoxP 70 (2018) s. 742-745.

Szram M. (rec.), D. Spychała, Przemiany religijne i kulturowe $w$ zachodnich prowincjach Cesarstwa Rzymskiego od roku 306 do śmierci św. Augustyna, t. 1-2, Bydgoszcz: Wydawnictwo Uniwersytetu Kazimierza Wielkiego 2016 - VoxP 68 (2017) s. 696-702.

Szram M. (rec.), K. Wendlik O.S.P.P.E., Serce to umyst. Mistyka spotkania Boga i człowieka w ujęciu Orygenesa oraz św. Augustyna - inspiracje IV Ewangelii, Kraków 2017 - VoxP 70 (2018) s. 756-758.

Szynkowski M. (rec.), Orygenes, Eustacjusz z Antiochii i Grzegorz z Nyssy, O wywotywaniu duchów. Czy wróżka z Endor wywołała ducha Samuela (1 Sm 28)?, red. Leon Nieścior OMI, Biblioteka Ojców Kościoła, Kraków 2016, Wydawnictwo m, ss. 160 - VoxP 68 (2017) s. 691-696.

Turek W. - Vasyl I. (rec.), M Starowieyski - J.M. Szymusiak, Nowy Stownik Wczesnochrześcijańskiego Piśmiennictwa, Wydanie drugie przepracowane i uzupełnione, przygotował ks. Marek Starowieyski przy współpracy Wojciecha Stawiszyńskiego, Poznań 2018, 1092 pp. - „Salesianum” 81/3 (2019) s. 573-575. [= Nuovo dizionario della letteratura cristiana delle origini, edizione seconda elaborata e completata, preparata da Marek Starowieyski in collaborazione di Wojciech Stawiszyński].

Witowski W. (rec.), A. Żurek, Katechumen - chrześcijanin - wierny: przygotowanie do chrztu i chrzest $w$ Kościele starożytnym, Teologia dla wszystkich 12, Tarnów: Wydawnictwo Biblos, 2017 - VoxP 72 (2019) s. 302-307.

\section{Sprawozdania}

Drączkowski F., Teologia $i$ duchowość monastyczna $w$ epoce patrystycznej (Sekcja Patrystyczna, Tyniec, 19-21 IX 2017): Laudacja na cześć Jubilata-ks. prof. Dr hab. Bogdana Częsza, VoxP 70 (2018) s. 766-768.

Figiel J., Egzegeza biblijna wczesnochrześcijańskiego wschodu i jej echa na Zachodzie (Sekcja Patrystyczna, Góra Św. Anny, 19-21 IX 2016), VoxP 68 (2017) s. 792-794.

Figiel J., Międzynarodowa Konferencja w Ołomuńcu (Palacký University, 15-16 VI 2017), VoxP 68 (2017) s. 824-826.

Figiel J., Origeniana duodecima (Jerozolima 25-26 VI 2017), VoxP 68 (2017) s. 830-832. 
Groń R., LIV Międzynarodowy Kongres Studiów nad Średniowieczem oraz Konferencja Studiów Cysterskich i Monastycznych, (Kalamazoo, MI, USA, 9-12 maja 2019), VoxP 72 (2019) s. 340-342.

Grzywaczewski J., Uroczystość nadania doktoratu honoris causa Papieskiego Wydziatu Teologicznego w Warszawie Księdzu Profesorowi Markowi Starowieyskiemu (Warszawa, 12 XII 2017). Prezentacja działalności i dorobku Księdza Profesora Marka Starowieyskiego, VoxP 70 (2018) s. 792-804.

Grzywaczewski J., Uroczystość wręczenia księgi jubileuszowej (64. tomu „Vox Patrum”) Księdzu Profesorowi Józefowi Wolińskiemu (Paryż - Issy-les-Moulineaux, 1 X 2016), VoxP 68 (2017) s. 797-801.

Jóźwiak M., Biblia w interpretacji i egzegezie. (IV Międzynarodowa Konferencja Biblijna, Ostrów Wielkopolski, 24-25 V 2017), VoxP 68 (2017) s. 815-817.

Kamczyk W., "Chrześcijaństwo w Afryce Prokonsularnej». Sprawozdanie ze spotkania Sekcji Patrystycznej przy Komisji ds. Nauki Katolickiej Konferencji Episkopatu Polski (Kalisz, 18-20 września 2018), ŚSHT 51/2 (2018) s. 506-508.

Kamczyk W., «Teologia i duchowość monastyczna w epoce patrystycznej». Sprawozdanie ze spotkania Sekcji Patrystycznej przy Komisji ds. Nauki Katolickiej Konferencji Episkopatu Polski (Tyniec, 19-21 września 2017), ŚSHT 50/2 (2017) s. 498-502.

Kochanek P., Biblia w ttumaczeniach (V Międzynarodowa Konferencja Biblijna, Ostrów Wielkopolski, 14-15 V 2018), VoxP 70 (2018) s. 805-808.

Kochanek P., «Foenus hoc fecit» W kręgu badań Profesora Stanisława Mrozka (Gdańsk, UG, 25-26 VI 2018), VoxP 70 (2018) s. 810-813.

Kochanek P., Historia Bizancjum w programie VI Kongresu Mediewistów Polskich (Wrocław, 20-22 września 2018), VoxP 72 (2019) s. 329-335.

Kochanek P., Meministi? Pamięć i niepamięć w świecie starożytnym, świat starożytny w pamięci i niepamięci (Poznań, 20-22 IX 2017), VoxP 70 (2018) s. 770-778.

Kochanek P., Międzynarodowa Konferencja Naukowa «Pneumatologia Ojców Kościoła», (Lublin, 17 maja 2019), VoxP 72 (2019) s. 343-344.

Kochanek P., IV Ogólnopolska Konferencja Bizantynistyczna z cyklu «Wybrane aspekty kultury bizantyńskiej» pt. «Stowo i obraz w kulturze bizantyńskiej» (Lublin 16-17 XI 2017), VoxP 70 (2018) s. 784-787.

Kochanek P., Ogólnopolska konferencja naukowa w ramach cyklu «z duchowości bizantyńskiej»: święte wizerunki w starożytności chrześcijańskiej (Opole, UO, 10-11 V 2016), VoxP 68 (2017) s. 791-792.

Kochanek P., Ogólnopolska Konferencja Starożytnicza: «Siła i bezsilność władzy, zbiorowości i jednostki w świecie grecko-rzymskim i bizantyńskim» (Lublin - Dąbrowica, KUL-UMCS, 18-19 V 2017), VoxP 68 (2017) s. 811-815.

Kochanek P., Ogólnopolskie seminarium naukowe «Przestrzenie kultury bizantyńskiej» (Poznań, UAM, 23 II 2017), VoxP 68 (2017) s. 807-808.

Kochanek P., Posiedzenia Komisji Bizantynologicznej Polskiego Towarzystwa Historycznego (KB PTH) w roku akademickim 2016/2017, VoxP 68 (2017) s. 804-807. 
Kochanek P., Posiedzenia Komisji Bizantynologicznej Polskiego Towarzystwa Historycznego (KB PTH) w roku akademickim 2017/2018, VoxP 70 (2018) s. 787-791.

Kochanek P., Posiedzenia Komisji Bizantynologicznej Polskiego Towarzystwa Historycznego (KB PTH) w roku akademickim 2018/2019, VoxP 72 (2019) s. 325-328.

Kochanek P., Teodora Lektora «Historia Kościoła»: gatunek, tradycja, tekst (Kraków, UP KEN, 1-2 VI 2017), VoxP 68 (2017) s. 823-824.

Misiarczyk L., Hieronymus noster. Międzynarodowe Sympozjum z okazji 1600-letniej rocznicy śmierci, (Ljubljana, Słowenia, 23-26 X 2019), VoxP 72 (2019) s. 347-349.

Nawarra M. - Prus W., Teologia i duchowość monastyczna w epoce patrystycznej (Sekcja Patrystyczna, Tyniec, 19-21 IX 2017): Życzenia przedstawicieli środowisk zakonnych do Jubilata - ks. prof. dr. hab. Bogdana Częsza, VoxP 70 (2018) s. 769-770.

Pyszna J. - Laurynenka K., Sprawozdanie z wyjazdu naukowego do Rzymu doktorantów Instytutu Historii Kościoła i Patrologii KUL w dniach 5-11 maja 2019 r., VoxP 72 (2019) s. 335-340.

Stawiszyński W., Uroczystość nadania doktoratu honoris causa Papieskiego Wydziału Teologicznego w Warszawie Księdzu Profesorowi Markowi Starowieyskiemu (Warszawa, 12 XII 2017), VoxP 70 (2018) s. 791-792.

Szczur P., Antyczne źródła i ich współczesne interpretacje (Lublin, KUL, 6-7 X 2017), VoxP 70 (2018) s. 782-784.

Szczur P., Chrześcijanie Wschodu. 2000 lat historii (Paryż, 26 IX 2017 - 14 I 2018), VoxP 70 (2018) s. 778-782.

Szczur P., Doroczne spotkanie Kanadyjskiego Stowarzyszenia Studiów Patrystycznych (Toronto, Ryerson University, 28-30 V 2017), VoxP 68 (2017) s. 818-822.

Szczur P., Myśl teologiczna św. Marka Eremity (V w.) (Warszawa, UKSW, 20 VI 2018), VoxP 70 (2018) s. 808-810.

Szczur P., XIII Studencka Konferencja Starożytnicza: «Cantata quae nescierim melius». Magia, czary i wróżbiarstwo w starożytności” (Kraków, UJ, 12-14 V 2017), VoxP 68 (2017) s. 808-811.

Szczur P., Sztuka nubijska w kontekście bizantyńskim, etiopskim i koptyjskim (Warszawa, UKSW, 25-26 XI 2016), VoxP 68 (2017) s. 802-804.

Szczur P., Teologia i duchowość monastyczna w epoce patrystycznej (Sekcja Patrystyczna, Tyniec, 19-21 IX 2017), VoxP 70 (2018) s. 763-765.

Szczur P., Uroczystość wręczenia Księgi Jubileuszowej (64. tomu ,,Vox Patrum”) Księdzu Profesorowi Józefowi Wolińskiemu (Paryż - Issy-les-Moulineaux, 1 X 2016), VoxP 68 (2017) s. 794-797.

Wysocki M., Osiemnasta Międzynarodowa Konferencja Studiów Patrystycznych (Oksford, 19-23 VIII 2019), VoxP 72 (2019) s. 344-346. 


\section{Wybrane publikacje z zakresu literatury klasycznej}

\subsection{Przekłady}

Anonim, Przedstawienie całego świata i jego ludów (Expositio totius mundi et gentium),

tł., wstęp i kom. M. Wojcieszak, VoxP 69 (2018) s. 817-836.

Antologia liryki hellenistycznej, tł. J. Danielewicz, Warszawa: Wydawnictwo Naukowe

PWN, 2018 (edycja dwujęzyczna).

Antologia przekładów, red. A. Arndt - M. Miazek-Męczyńska - M. Stuligrosz - P. Urbański, w: Aetas Aurea [1], s. 155-443.

Apollodor, Biblioteka opowieści mitycznych (Bibliothéke), tł., wstęp i przyp. T. Mojsik,

Biblioteka Antyczna 60, Wrocław: Instytut Studiów Klasycznych, Śródziemnomorskich i Orientalnych Uniwersytetu Wrocławskiego, 2018.

Aristainetos, Listy o miłości, tł., wstęp i przyp. M. Szarmach, Toruń: Wydawnictwo Naukowe UMK, 2019.

Arystobul, Testimonia i fragmenty, tł. T. Bednarek, „Studia Antyczne i Mediewistyczne” 16 [51] (2018) s. 23-40.

Arystoteles, Metafizyka, opr. M.A. Krąpiec - A. Maryniarczyk, Lublin: Polskie Towarzystwo Tomasza z Akwinu, 2017 (wydanie polsko-grecko-łacińskie).

Arystoteles, Peri hermeneias (Hermeneutyka), tł., wstęp, przyp. i kom. T. Tiuryn, Ad Fontes 29, Kęty: Wydawnictwo Marek Derewiecki, 2018 (edycja dwujęzyczna).

Awian [Awianus], Bajki [Fabulae], tł. D. Budzanowska-Weglenda, rewizja przekładu I. Radziejowska, wstęp i kom. D. Budzanowska-Weglenda - M. Mejor, Bibliotheca Litterarum Medii Aevi Artes - Opera (Opera nr 5), Warszawa: Wydawnictwo IBL PAN, 2018 (wydanie dwujęzyczne).

Bajki z Mezopotamii i akadyjskie utwory humorystyczne, tł. O. Drewnowska-Rymarz M. Kapełuś - A. Kopydłowska - K. Łyczkowska - A. Szymkuć, Warszawa: Wydawnictwo Agade, 2018.

Celsus Aulus Korneliusz, A. Korneliusza Celsa O lecznictwie ksiag ośmioro, tł. H. Łuczkiewicz, Warszawa: Wydawnictwo Grafika, 2019 (przedruk metodą fotooffsetową wydania z 1889 roku).

Diodor Sycylijski, Starożytności asyryjskie i indyjskie (Biblioteka Historyczna II), tł. M. Wróbel, wstęp S. Dworacki, kom. L. Mrozewicz, Fontes Historiae Antiquae 34, Poznań: Wydawnictwo Naukowe UAM, 2017 (wydanie dwujęzyczne).

Diodor Sycylijski, Starożytności etiopskie i libijskie (Biblioteka Historyczna III), tł., wstęp i kom. M. Wróbel, Fontes Historiae Antiquae 38, Poznań: Wydawnictwo Naukowe UAM, 2018 (wydanie dwujęzyczne). 
Diodor Sycylijski, O wyspach (Biblioteka Historyczna V), tł. I. Musilska, kom, L. Mrozewicz, Fontes Historiae Antiquae 35, Poznań: Wydawnictwo Naukowe UAM, 2018 (wydanie dwujęzyczne).

Diodor Sycylijski, Wojny grecko-perskie (Biblioteka Historyczna XI), tł., wstęp i kom. I Ptaszek, Fontes Historiae Antiquae 37, Poznań: Wydawnictwo Naukowe UAM, 2018 (wydanie dwujęzyczne).

Diodor Sycylijski, O Peryklesie $i$ wojnie peloponeskiej (Biblioteka Historyczna XII), tł. A. Skucińska, kom. L. Mrozewicz, Fontes Historiae Antiquae 41, Poznań: Wydawnictwo Naukowe UAM, 2019 (wydanie dwujęzyczne).

Diodor Sycylijski, Klęska Ateńczyków (Biblioteka Historyczna XIII), tł. R. Turasiewicz, kom. L. Mrozewicz, Fontes Historiae Antiquae 43, Poznań: Wydawnictwo Naukowe UAM, 2019 (wydanie dwujęzyczne).

Diodor Sycylijski, O Dionizjuszu Starszym, tyranie Syrakuz (Biblioteka Historyczna XIV), tł. i kom. I. Ptaszek, konsultacja historyczna L. Mrozewicz, Fontes Historiae Antiquae 40, Poznań: Wydawnictwo Naukowe UAM, 2019 (wydanie dwujęzyczne).

Diodor Sycylijski, O Agatoklesie i Antygonie Jednookim (Biblioteka Historyczna XIX), tł. T. Polański, kom. L. Mrozewicz, Fontes Historiae Antiquae 42, Poznań: Wydawnictwo Naukowe UAM, 2019 (wydanie dwujęzyczne).

Diodor Sycylijski, Rok królów (Biblioteka Historyczna XX), tł. i wstęp T. Polański, kom. L. Mrozewicz, Fontes Historiae Antiquae 44, Poznań: Wydawnictwo Naukowe UAM, 2019 (wydanie dwujęzyczne).

Dion z Prusy (Złotousty), Druga, czwarta, trzecia «Mowa o królestwie», tł., opr. i kom.

K. Tuszyńska, Rhetores Graeci 2, Poznań: Wydawnictwo Naukowe UAM, 2018 (wydanie dwujęzyczne).

Epos o Gilgameszu. Wersja standardowa z Niniwy (ša naqba imuru), wpr., tł. i kom. A. Tronina, Kraków-Mogilany: The Enigma Press, 2017.

Eurypides, Tragedie, tom 1: Alkestis, Medea, Dzieci Heraklesa, Hipolit, Hekabe, Błagalnice, Andromacha, Oszalaty Herakles, Trojanki, tł. R.R. Chodkowski, Lublin: Towarzystwo Naukowe KUL, 2017.

Eurypides, Tragedie, tom 2: Elektra, Ifigenia w kraju Taurów, Ijon, Helena, Fenicjanki, Orestes, Bachantki, Ifigenia w Aulidzie, Rezos, tł. R.R. Chodkowski, Lublin: Towarzystwo Naukowe KUL, 2018.

Flegon z Tralles, $O$ dziwach $i$ ludziach dtugo żyjacych, tł. i opr. E. Żybert, Bibliotheca Curiosa 35, Wrocław: Oficyna Wydawnicza ATUT - Wrocławskie Wydawnictwo Oświatowe, 2019.

Frontinus, $O$ akweduktach miasta Rzymu; Traktaty miernicze [O kategoriach gruntów, O sporach, O liniach działowych, O sztuce mierniczej], red. A. Pikulska-Radomska K. Tadajczyk, Łódź, Wydawnictwo Uniwersytetu Łódzkiego, Łódź 2017 [O akweduktach miasta Rzymu tł. C. Kunderewicz: Warszawa: Instytut Historii Kultury Materialnej PAN, 1961, przejrzał i poprawił K. Tadajczyk. Traktaty miernicze, tł. A. Maciejewska]. 
Galen, O formowaniu płodu 3-4, tł. J. Komorowska, „Studia Antyczne i Mediewistyczne” 16 [51] (2018) s. 49-56.

Julian Apostata - A. Pająkowska-Bouallegui, Twórczość epigramatyczna cesarza Juliana Apostaty, w: O poetach i poezji. Od antyku po współczesność. Studia i szkice dedykowane Pani Profesor Zofii Głombiowskiej, red. I. Bogumił - J. Pokrzywnicki, Wydawnictwo Uniwersytetu Gdańskiego, Gdańsk 2019, s. 207-213.

Julian Apostata, Mowa III: Mowa pochwalna na cześć cesarzowej Euzebii, tł., wstęp i objaśnienia A. Pająkowska, Fontes Historiae Antiquae 45, Poznań: Wydawnictwo Naukowe UAM, 2019.

Kallimach, Dzieła poetyckie, t. 2, tł. A. Kotlińska-Toma - E. Żybert-Pruchnicka, Biblioteka Antyczna 55, Wrocław: Instytut Studiów Klasycznych, Śródziemnomorskich i Orientalnych Uniwersytetu Wrocławskiego, 2018.

Kasjusz Dion, Historia rzymska, księgi seweriańskie (LXXIII-LXXX), wstęp, tł. i kom. K. Biały, Szczecin: Uniwersytet Szczeciński, 2017.

Ksenofont, Obrona Sokratesa, tł. i red. D. Tymura, Warszawa: Teologia Polityczna, 2019.

Ksenofont, Sympozjon i inne pisma, tł. A. Rapaport, Kęty: Wydawnictwo Marek Derewiecki, 2019.

Ktezjasz z Knidos, Fragmenty $w$ «Excerpta Constantiniana», wpr. K. Głombiowski, tł. i opr. A. Marchewka - K. Głombiowski, Gdańsk: Wydawnictwo Uniwersytetu Gdańskiego, 2019.

Kurcjusz Rufus, Historie Aleksandra Wielkiego, tł. H. Pietruszczak, Zgorzelec: Wydawnictwo Henryk Pietruszczak, 2019.

Lykofron, Aleksandra, tł., wstęp i przyp. E. Żybert-Pruchnicka, Biblioteka Antyczna 59, Wrocław: Instytut Studiów Klasycznych, Śródziemnomorskich i Orientalnych Uniwersytetu Wrocławskiego, 2018.

Menethon z Sebennytos, Dzieje Egiptu, tł, wstęp i kom. F. Taterka, Rhomaioi 8, Poznań: Wydawnictwo Naukowe UAM, 2017.

Muzoniusz Rufus, Czy wszystkie urodzone dzieci maja być wychowywane? Diatryba XV A-B, tł., wstęp i kom. S. Longosz, VoxP 69 (2018) s. 783-796.

Platon, Eutyfron, tł. i opr. R. Legutko, Warszawa: Teologia Polityczna, 2017.

Platon, Gorgiasz; tł., wstęp i przyp. W. Witwicki, Sandomierz: Wydawnictwo Armoryka, 2017 (reprint wydania: Lwów: b.w., 1922).

Platon, Lysis, tł. E. Osek, Warszawa: Teologia Polityczna, 2019.

Platon, Obrona Sokratesa, tł. R. Legutko, Warszawa: Teologia Polityczna, 2017.

Platon, Protagoras, tł. L. Regner, Warszawa: Wydawnictwo Aletheia, 2019.

Plaut, Komedie, t. 4: Wesele Bazylii, Skrzyneczka, tł., wstęp i przyp. E. Skwara, Biblioteka Antyczna 57, Wrocław: Instytut Studiów Klasycznych, Śródziemnomorskich i Orientalnych Uniwersytetu Wrocławskiego, 2017.

Pliniusz Młodszy, Korespondencja Pliniusza Młodszego z cesarzem Trajanem, t. 1: Tekst i tłumaczenie, A. Dębiński - M. Jońca - I. Leraczyk - A. Łuka; t. 2: Komentarze, red. A. Dębiński - M. Jońca - I. Leraczyk - A, Łuka, Lublin: Wydawnictwo KUL, 2017. 
Pliniusz Starszy, Historia naturalna, tom 1: Kosmologia i Geografia. Ksieggi II-VI, tekst, wstęp, tł. i kom. I. Mikołajczyk - N. Rataj - E. Twarowska-Antczak - K. Antczak Torun: Wydawnictwo Naukowe UMK, 2017.

Pliniusz Starszy, Historia naturalna, t. 2: Antropologia i Zoologia, Księgi VII-XI, tekst, wstęp, tł. i kom. I. Mikołajczyk, Toruń: Wydawnictwo Naukowe UMK, 2019.

Plutarch z Cheronei, Czy gorsze sa namiętności duszy, czy choroby ciała, tł., wst. i kom. A. Kucz, ,Scripta classica” 14 (2017) s. 9-17.

Plutarch z Cheronei, Gryllos, czyli o rozumności nierozumnych zwierząt, tł. i kom. K. Jażdżewska, „Meander” 72 (2017) s. 9-22.

Plutarch z Cheronei, Żywot Artakserksesa, wstęp, tł. i kom. B. Proc, Lublin: Wydawnictwo KUL, 2019 (edycja dwujęzyczna).

Plutarch, -Pseudo, O nazwach rzek i gór oraz o tym, co się tam znajduje, tł. i opr. E. Żybert, Bibliotheca Curiosa 31, Wrocław: Oficyna Wydawnicza ATUT - Wrocławskie Wydawnictwo Oświatowe, 2018.

Porfiriusz z Tyru, O wegetarianizmie, wprowadzenie, tł. i kom. E. Osek, Warszawa: Wydawnictwo Naukowe Sub Lupa, 2018 (edycja dwujęzyczna).

Prawa Hammurabiego. Dīnāt mī̌sarim, tł. i opr. W. Tyborowski, Poznań: Wydawnictwo Naukowa UAM, Poznań 2019.

Repozjanus, O schadzce Marsa $i$ Wenery, tł. i kom. N. Cichoń, „Scripta Classica” 15 (2018) s. 51-61.

Scholia on Pausanias, red. M. Sobolewska - K. Narecki, Kraków: Wydawnictwo scriptum, 2018 (wydanie anglojęzyczne).

Seneka, Edyp, wstęp, tł. i kom. T. Sapota - I. Słomak, Katowice: Wydawnictwo Uniwersytetu Śląskiego, 2017.

Sekstus Empiryk, Zarysy Pyrrońskie, tł., wstęp i przyp. Z. Nerczuk, Toruń: Wydawnictwo Naukowe UMK, 2019.

Sofokles, Tragedie, tom 1: Król Edypa, Edyp w Kolonos, Antygona, t. 2: Ajas, Filoktet, Elektra, Trachinki, tł. A. Libera, Warszawa: PIW, 2018.

Symplicjusz z Cylicji (Pseudo-), [Symplicjusza objaśnienia do drugiej księgi Arystotelesowego "O duszy», w: Jan Filiponos, Komentarz do Arystotelesowego "O duszy» II, 1-5. (Pseudo-) Symplicjusz, Komentarz do Arystotelesowego «O duszy» II, 1-5, tł., wstęp i przypisy J. Komorowska, Warszawa: Wydawnictwo Naukowe UKSW, 2018, s. 145-209.

Temistiusz, Parafraza księgi XII «Matafizyki» Arystotelesa, tł., wprow. i kom. M.A. Komsta, Lublin: Polskie Towarzystwo Tomasza z Akwinu, 2018 (edycja dwujęzyczna).

Waleriusz Maksymus, Czyny i powiedzenia godne pamięci $w$ dziewięciu księgach, tł., wstęp i kom. I. Lewandowski, Fontes Historiae Antiquae 39, Poznań: Wydawnictwo Naukowe UAM, 2019 (edycja dwujęzyczna).

Warron Marek Terencjusz, O języku łacińskim, t. 1: ks. V-VII, tł., wstęp i kom. B.J. Kołoczek, Kraków: Towarzystwo Wydawnicze Historia Iagellonica, 2019. 


\subsection{Opracowania}

Arnt A., Miód z nieba, rój z bydła, pszczeli król bez żądła - wizerunek pszczót w literaturze rzymskiej, w: Pszczoty, miód, wosk pszczeli w symboliczno-metaforycznych obrazach. Od Biblii poprzez antyk do liturgii Kościoła, red. I. Wieżel - G.M. Baran, Kraków: Wydawnictwo „Scriptum” 2018, s. 117-141.

Bednarek B., Ofiara krwawa w Grecji starożytnej w świetle danych filologicznych. Stara komedia attycka, Warszawa: Wydawnictwo Naukowe Sub Lupa, 2017.

Bednarek T. Wstęp do przekładu testimoniów i fragmentów Arystobula, „Studia Antyczne i Mediewistyczne" 16 [51] (2018) s. 17-21.

Bielawski K., Doświadczenie mistyczne $w$ mitraizmie, „Filozofia Chrześcijańska” 14 (2017) s. 53-70.

Bielawski K., Ofiara krwawa w Grecji starożytnej w świetle danych filologicznych. Tragedia attycka, Warszawa: Wydawnictwo Naukowe Sub Lupa, 2017.

Biernat P., Ofiara krwawa w Grecji starożytnej w świetle danych filologicznych. «Corpus Platonicum», «Corpus Hippocraticum», Warszawa: Wydawnictwo Naukowe Sub Lupa, 2017.

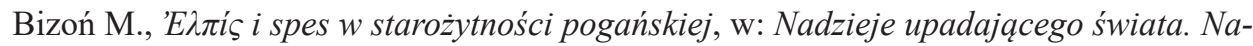
dzieja w chrześcijańskiej epistolografii łacińskiej IV i V wieku (Ambroży, Augustyn, Hieronim, Paulin z Noli), red. M. Wysocki - J. Pałucki - M. Pyzik-Turska, Lublin: Wydawnictwo KUL, 2019, s. 127-144.

Budzanowska-Weglenda D., "Perí tês filautias, filautia $i$ filautos» $w$ anonimowym komentarzu do «Etyki Nikomachejskiej» Arystotelesa, „E-Patrologos” 3/2 (2017) s. $18-31$.

Dembińska D., Moja krótka historia filozofii starożytnej (V), „Studia Redemptorystowskie" 15 (2017) s. 11-46.

Dziuba A., Marcus Caelius Rufus and His Correspondence with Marcus Tullius Cicero, w: Nadzieje upadającego świata. Nadzieja w chrześcijańskiej epistolografii łacińskiej IV i V wieku (Ambroży, Augustyn, Hieronim, Paulin z Noli), red. M. Wysocki J. Pałucki - M. Pyzik-Turska, Lublin: Wydawnictwo KUL, 2019, s. 47-60.

Gibbon E., Zmierzch cesarstwa Rzymskiego, t. 1-2, tł. S. Kryński (t. 1), Z. Kiersztyn (t. 2), Warszawa: PIW, 2017 (wznowienie).

Gibbon E., Upadek cesarstwa rzymskiego na Zachodzie, tł. I. Szymańska, Warszawa: PIW 2017 (wznowienie).

Goldsworthy A., Pax Romana. Wojna, pokój i podboje w świecie rzymskim, tł. N. Radomski, Poznań: Wydawnictwo Rebis, 2018.

Grainger J.D., Nerwa i problem sukcesji w Rzymie w latach 96-99, t1. W. Brillowski, Oświęcim: Wydawnictwo Napoleon V, 2017.

Gryksa E., Obraz Rzymu u Florusa, Tarnów: Wydawnictwo Biblos, 2017.

Holland R., Oktawian August. Ojciec chrzestny Europy, t1. A. Kowalska, Warszawa: Wydawnictwo Amber, 2019. 
Janiszewski P., Afrodyta Urania. Fizyczne, mistyczne i teurgiczne teofanie niebiańskiej bogini w czasach późnego antyku, Warszawa: Wydawnictwo Naukowe Sub Lupa, 2017.

Janiszewski P., Unio mystica. Opium, gazy halucynogenne i instrumenty teurgiczne w kręgach filozofów neoplatońskich późnego antyku, PHis 108/2 (2017) s. 205-232.

Kaczanowicz M., Egipt. Ostatnie wieki imperium (747-332 p.n.e.), Poznań: Wydawnictwo Naukowe UAM, 2019.

Karczewska H., «Corona triumphalis» - znaczenie i symbolika w starożytnym Rzymie, SaeCh 25 (2018) s. 33-41.

Komorowska J., Galena «O formowaniu płodu». Zarys problematyki i filozoficzne implikacje traktatu, „Studia Antyczne i Mediewistyczne” 16 [51] (2018) s. 41-48.

Kostuch L., Nieboskłon Hellenów - nieboskłon barbarzyńców. Solarne asocjacje Herodota, w: Niebo. Tradycje, przekazy, inspiracje [1], s. 179-188.

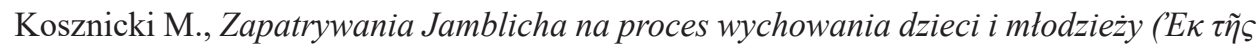

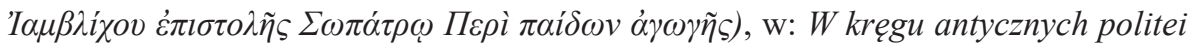
[1], s. 188-194.

Krajewska J., «Artefix Medicinae», czyli o Celsusie $i$ «De Medicina». Wybrane zagadnienia, SaeCh 26/1 (2019) s. 5-14.

Krajewska J., Nie tylko «O sztuce lekarskiej»w wybranych pismach Corpus Hippocraticum, SaeCh 25 (2018) s. 54-62.

Królczyk K., Rzymskie prowincje nad Renem i Dunajem w okresie flawijskim (69-96 r. po Chr.) - res militares et externae, Poznań: Wydawnictwo Naukowe UAM, 2019.

Kruczkiewicz B., Epigrafika rzymska. Wykłady uniwersyteckie, przedsłowie i przyp. L. Mrozewicz, Poznań: Wydawnictwo Naukowe UAM, 2019.

Kryza A., Drakologia starożytna. Motyw smoka w literaturze pozabiblijnej, CT 87/3 (2017) s. 67-96.

Lengauer W., Wino i Eros, PHis 108/2 (2017) s. 435-440.

Kucz A. - Gryksa E., Nemezjan w kręgu antycznej tradycji łowieckiej, Katowice: Wydawnictwo Uniwersytetu Śląskiego, 2019.

Levick B., Wespazjan, t1. M. Baranowski, Oświęcim: Wydawnictwo Napoleon V, 2019.

Loska E., Pozycja prawna aktorów w starożytnym Rzymie, Warszawa: Wydawnictwo UKSW, 2018.

Łuć I., Wojskowe monety Nerona. Typy ADLOCVT COH i DECVRSIO, VoxP 67 (2017) s. 361-372.

Mleczek A., Dekadencja moralna społeczeństwa rzymskiego w «Res Gestae» Ammiana Marcellina, Kraków: Wydawnictwo UJ, 2018.

Mrugalski D., «Agnostos Theos»: Relacja między nieskończonościa a niepoznawalnościa Boga w doktrynach medioplatoników, „Roczniki Filozoficzne” 67/3 (2019) s. 25-51.

Nieścior L., Arystoteles i poprzednicy o miłości własnej (filautia), „E-Patrologos” 3/2 (2017) s. 5-17.

Nowakowska M., Starożytna Grecja od kuchni, Warszawa: Wydawnictwo Naukowe PWN, 2017. 
Okoń D., Album senatorum, t. 1: Senatores ab Septimii Severi aetate usque ad Alexandrum Severum (193-235 AD), t. 2: Senatorowie epoki Sewerów (193-235 r. n.e.). Studium prozopograficzne, Szczecin: Wydawnictwo Naukowe Uniwersytetu Szczecińskiego, 2017.

Pająkowska-Bouallegiu A., Homer w pismach satyrycznych cesarza Juliana Apostaty («Cesarze» oraz «Misopogon czyli Nieprzyjaciel brody»), w: W kręgu antycznych politei [1], s. 306-318.

Pietrzak D., Ab inferis ad rostra. Przywotywanie zmartych $w$ retoryce rzymskiej okresu republikańskiego, Katowice: Wydawnictwo Uniwersytetu Śląskiego, 2019.

Roux G., Mezopotamia, tł. B. Kowalska - J. Kozłowska, Warszawa: Wydawnictwo Akademickie DIALOG, 2018.

Różycki Ł., Strach i motywacja na późnoantycznym polu bitwy w świetle rzymskich traktatów wojskowych, Seria: Labarum XIV, Poznań: Instytut Historii UAM, 2018.

Rybowska J., Zbożność i bezbożność w kulturze Greków, Łódź: Wydawnictwo Uniwersytetu Łódzkiego, 2017.

Schrödinger E., Przyroda i Grecy. Nauki przyrodnicze i humanistyczne, tł. K. Napiórkowski, Warszawa: Wydawnictwo ISiF PAN, 2017.

Sowa J., «Toksaris» albo «O przyjaźni» Lukiana z Samosat - ideat czy parodia?, VoxP 71 (2019) s. 447-473.

Szeląg T., Cesarz Julian Aspostata i jego ustawa szkolna, Zabrze-Tarnowskie Góry: Wydawnictwo inforteditions, 2017.

Wasilewski M., Pedagogika grecka. Od Protagorasa do Posejdoniosa, Łódż: Wydawnictwo Uniwersytetu Łódzkiego, 2017.

Węcławski M., Dylemat więźnia. Ostracyzm ateński i jego pierwotne cele, Toruń: Wydawnictwo Naukowe UMK, 2018.

Wieżel I., Pszczoły w antycznej mitologii i literaturze greckiej-wybór źródet, w: Pszczoły, miód, wosk pszczeli w symboliczno-metaforycznych obrazach. Od Biblii poprzez antyk do liturgii Kościoła, red. I. Wieżel - G.M. Baran, Kraków: Wydawnictwo scriptum, 2018, s. 95-116.

Wojciechowski M., Modlitwy greckie epoki hellenistycznej, Olsztyn: Wydział Teologii Uniwersytetu Warmińsko-Mazurskiego, 2017.

Wypustek A., Imperium szamba, ścieku $i$ wychodka. Przyczynek do historii życia codziennego w Starożytności, Warszawa: Wydawnictwo Naukowe Sub Lupa, 2018.

Zarewicz D., Przywoływanie bogów - mit, magia, misteria w starożytnej Grecji, Warszawa: Wydawnictwo Naukowe Sub Lupa, 2017.

Zebrał i opracował Wojciech Stawiszyński 